Florida International University FIU Digital Commons

$10-24-2011$

\title{
La Kábala Dentro del Discurso Contemporáneo y Urbano: El Ejemplo de Marcos Ricardo Barnatán
}

Janet Otero Toledo

Florida International University, joter005@fiu.edu

DOI: $10.25148 /$ etd.FI11120202

Follow this and additional works at: https://digitalcommons.fiu.edu/etd

Part of the Spanish and Portuguese Language and Literature Commons

\section{Recommended Citation}

Otero Toledo, Janet, "La Kábala Dentro del Discurso Contemporáneo y Urbano: El Ejemplo de Marcos Ricardo Barnatán" (2011). FIU Electronic Theses and Dissertations. 473.

https://digitalcommons.fiu.edu/etd/473 
FLORIDA INTERNATIONAL UNIVERSITY

Miami, Florida

\section{LA KÁBALA DENTRO DEL DISCURSO CONTEMPORÁNEO \\ Y URBANO: EL EJEMPLO DE MARCOS RICARDO BARNATÁN}

A dissertation submitted in partial fulfillment of the

requirements for the degree of

DOCTOR OF PHILOSOPHY

in

SPANISH

by

Janet Otero Toledo

2011 
To: Dean Kenneth G. Furton

College of Arts and Sciences

This dissertation, written by Janet Otero Toledo, and entitled La Kábala dentro del discurso contemporáneo y urbano: el ejemplo de Marcos Ricardo Barnatán, having been approved in respect to style and intellectual content, is referred to you for judgment.

We have read this dissertation and recommend that it be approved.

Maida Watson

Renee Silverman

Ana María Bidegain

Santiago Juan-Navarro, Major Professor

Date of Defense: October 24, 2011

The dissertation of Janet Otero Toledo is approved.

Dean Kenneth G. Furton

College of Arts and Sciences

Dean Lakshmi N. Reddi

University Graduate School

Florida International University, 2011 


\section{DEDICATORIA}

Hashem,

Te alabaré con todo mi corazón; delante de ministros cantaré a Ti. Me prosternaré frente al recinto de Tu santidad y alabaré Tu nombre, por Tu benevolencia y Tu verdad, pues has engrandecido Tu palabra más que todo Tu Nombre. En el día que invoqué, me has respondido; has infundido en mi alma la fuerza. Te alabarán, Hashem, todos los reyes de la tierra, pues han escuchado las palabras de Tu boca. Y cantarán acerca de los caminos de Hashem, pues grande es el honor de Hashem.

(Salmo, 138 para Shabat)

Me gustaría dedicarle esta tesis a mi madre, hija y abuela.

Para mi madre, Elvira, por su ayuda y comprensión en todo momento. Ella ha estado a mi lado desafiando los infortunios sin perder la mesura ni desfallecer en el intento.

A mi hija, María Carla. Ella es lo mejor que nunca me ha pasado. Ella es mi referente para el presente y para el futuro.

Finalmente, a mi abuela, Caridad, que no se encuentra en este mundo. Ella me dio mis valores, mis principios, mi perseverancia y mi empeño y todo ello con enormes dosis de amor.

A todas ellas, muchas gracias de todo corazón. 


\section{AGRADECIMIENTOS}

Quisiera agradecer a los miembros de mi comité por su sabía guía, paciencia y asesoramiento profesional. Recordaré, siempre, esta lección de organización y síntesis que ellos me han impartido, mientras dirigían con gentileza y firmeza mi disertación.

La Dra. Maida Watson fue sensible, inteligente y estimulante con su confianza incondicional en mis habilidades, muy por encima de mis propias expectativas, no solamente en este proceso final sino a través de toda mi carrera. Ella fue la que me sugirió que escribiera mi tesis doctoral sobre el misticismo judío al verme tan interesada en el tema. Su orientación metodológica ha sido de un gran valor. Quiero también agradecer a la Dra. Ana Maria Bidegain por su disponibilidad invariable desde el inicio.

El Dr. Santiago Juan Navarro me ha proporcionado consistente información para culminar con éxito la disertación. Su apoyo técnico y académico ha sido crucial para el desarrollo de este trabajo junto con sus acertadas correcciones.

Además quiero expresar mi gratitud a Dra. Renee Silverman por los altos estándares con que ha evaluado mi manuscrito, refinado mi estilo y desarrollado mis aptitudes literarias.

Gracias a los cuatro admirados profesores por su dirección y colaboración.

Finalmente quiero agradecer al Department of Foreign Languages y al University Graduate School de Florida International University por ofrecerme esta oportunidad. 


\title{
ABSTRACT OF THE DISSERTATION \\ LA KÁBALA DENTRO DEL DISCURSO CONTEMPORÁNEO Y URBANO: EL EJEMPLO DE MARCOS RICARDO BARNATÁN
}

\author{
by \\ Janet Otero Toledo \\ Florida International University, 2011 \\ Miami, Florida

\section{Professor Santiago Juan Navarro, Major Professor}

This dissertation analyzes the relationship between several mystic Sephardic texts called the Kabalah which include the three basic mystic books of Judaism: Sefer Yetsira, Sefer Bahir, and Sefer Zohar, and Argentine writer of Jewish descent, Marcos Ricardo Barnatan's experimental work. The premise is that several mystic Sephardic texts have certain literary characteristics that make them fertile sources for the inspiration of writers like Barnatan. This thesis proves that Barnatan's poetry and his first novel El Laberinto De Sion both use the most general concepts of the Kabalah in developing his literary and artistic creations.

This study is focuses on the concept that there exists a possibility of reading kabalistic texts not only in an exegetical way, but also in a poetic way. Barnatan's literature is prone to this kind of reading of the texts. He creates a surprisingly expressive structure without ties to established models. This expressive structure is built on a vast amount of symbols, which results from this freedom. Barnatan adopts multiple symbols from cosmogenic theories and makes use of them, thus incorporating both the spirit and style of kabalistic texts into his own work.

Instead of addressing some of the main concerns of Kabbalistic study and its commentary, Barnatan avoids the concern for Law, the study of the Torah and its 
commentaries, while avoiding the use of the Hebrew language. For this reason

Barnatan is too deviant to be considered an extension from the mainstream

Kabbalistic commentary. Barnatan's work is destined for a reader who cannot only understand his experimental methods, but who can also assemble a disjointed text while accepting a fundamental instability of space and time. 


\section{ÍNDICE}

CAPÍTULO

PÁGINA

INTRODUCCIÓN 1

1. CONTEXTO RELIGIOSO - LITERARIO DE MARCOS RICARDO

BARNATÁN. CARACTERÍSTICAS DE SU OBRA .

1.1 La Kábala dentro del discurso contemporáneo y urbano: el ejemplo de

Marcos Ricardo Barnatán.

1.2 Marcos Ricardo Barnatán entre la mística judía, el postmodernismo y el

boom

1.3 Tres libros místicos judíos: Séfer Yetsirá (El libro de la Creación), Séfer

Bahir (El libro de la Claridad), y el Séfer ha Zohar (El libro del Esplendor) ....34

1.4 La intertextualidad artística en la obra de Marcos Ricardo Barnatán .............44

2. ENCUENTRO ENTRE POESÍA Y KÁBALA: ALGUNOS CONCEPTOS EN

COMÚN

2.1. La contracción del espíritu (Tsimtsum)........................................................71

2.2. Una experiencia bilateral: beneficio y enriquecimiento en los dos sentidos.

2.3. La Kábala reivindicada por la poesía

2.4. El lenguaje práctico cuando de lo inefable trata

3. MULTICULTURALIDAD NARRATIVA EN EL LABERINTO DE SIÓN 125

3.1. El laberinto de Sión a la luz de la teoría literaria

3.2 La Torá: un ejemplo de texto polifónico postmodernista

3.3. La responsabilidad del hombre ante el texto. La realidad como invención constante 150

3.4. El laberinto de Sión: un mundo urbano carente de la idea de lo divino .......162

CONCLUSIONES

BIBLIOGRAFÍA 181

VITA 190 
Rosa, oh contradicción, pura en el deleite de ser el sueño de nadie bajo tantos párpados.

Epitafio de Rilke

\section{INTRODUCCIÓN}

Un rasgo que no cesa de despertar el asombro y la admiración de los lectores y críticos es la prodigiosa erudición y la gran diversidad de fuentes filosóficas en las que se inspira un numeroso grupo de escritores contemporáneos. En dicho grupo destaca el narrador y poeta Marcos Ricardo Barnatán, nacido en el seno de una familia bonaerense sefardita en 1946. Cursó estudios de Filosofía y Letras en su ciudad natal, y a los 18 años se trasladó a España. En ese país fijó su residencia, aunque realizó frecuentes viajes a su tierra natal. Ha publicado varias obras, tanto en poesía como en prosa. Su primera novela, El laberinto de Sión (1971), inicia una trilogía que fue muy elogiada por escritores de la talla de Juan Goytisolo, Guillermo Cabrera Infante y Severo Sarduy, para quienes representa uno de los pocos intentos de renovación del género. Las dos obras que completan la trilogía son Gor (1973) y Diano (1982).

En lo que respecta a su producción poética, Barnatán publicó los poemarios Los pasos perdidos, El libro del Talismán, Arcana mayor, La escritura del vidente y El oráculo invitado, todos ellos reunidos en la compilación titulada como su último poemario: El oráculo invocado (1984). Barnatán es excepcional dentro de la promoción española de los 'novísimos', como se seguirá detallando más adelante en este mismo trabajo. 
Este gran novelista, ensayista y poeta es autor de una original obra en la que se advierte una constante: las alusiones a la cultura judía sefardita y a la Kábala. La inclusión de la Kábala en la lista de referencias del mundo de muchos escritores como es el caso que nos ocupa — tiene como intención asediar la realidad y derrocarla, como quedará probado al finalizar esta investigación.

Es interesante destacar que Barnatán ha profundizado en la prosa borgiana, debido a lo cual es considerado como uno de los más importantes biógrafos contemporáneos de Jorge Luis Borges.

En una entrevista ${ }^{1}$ concedida a Gabriel Contreras, Barnatán explica que empezó a estudiar la obra borgiana en la década de 1970. En esta entrevista, confiesa que cuando empezó a leer al autor argentino, a los 17 años, no sintió mucho interés, principalmente debido a los prejuicios fomentados por la extrema izquierda de su país. Fue en 1965, ya en España, cuando retomó a Borges y a interesarse por su obra.

En uno de sus frecuentes viajes a la Argentina, Barnatán empezó a acudir a los mismos restaurantes donde Borges solía almorzar, asistió a todas las conferencias que este dictaba y, como él mismo afirma, “espiaba hasta lo que hablaba con sus visitantes (Barnatán, Borges, biografía total 12). Poco después se decidió a llamarlo por teléfono y a iniciar una serie de largas y productivas charlas con el genial autor de $E l$ Aleph. Estas pláticas, según Barnatán, se convirtieron en una rutina que perduró hasta la muerte del escritor.

Fue así como Barnatán se conectó profundamente con la obra de Borges pero, además, adquirió un especial interés por la obra de Gershom Scholem —académico

\footnotetext{
${ }^{1}$ Para más información véase: Espéculo. Revista de estudios literarios. Universidad Complutense de Madrid, 2000.
} 
muy admirado por el brillante autor argentino — a quien Barnatán dedica su primera novela: El laberinto de Sión.

El interés de Barnatán por la mística judía sefardita data, sin embargo, de cuando el poeta era adolescente. Incluso él mismo reconoce que comenzó leyendo el Séfer ha Zohar en una versión traducida al español por Eliphas Leví, destacado ocultista francés, quien difundió y adulteró algunos fragmentos del libro. Más adelante, Barnatán consultó la versión francesa de Jean de Pauly aunque según afirma, “esta versión carece de validez para Gershom Scholem” (Barnatán, Antología del Zohar 11). Fue entonces cuando estudió la antología seleccionada por el propio Gershom Scholem para Schoken Books en New York, y con la versión al español de León Dujovne, completó sus lecturas básicas. Su interés por la mística judía sefardita se hizo ininterrumpida y constante, y su creación literaria, al mismo tiempo, se convirtió en un reflejo de este interés, como se puede ver en su constante referencia a conceptos místicos.

En 1976, Marcos Ricardo sacó a la luz La Kábala, una mística del lenguaje. Como él mismo explica en el prólogo de la segunda edición de este mismo libro, diez años más tarde, la primera tirada fue escasa y en un formato popular. Ya en el año 1986, junto a la segunda edición de La Kábala, una mística del lenguaje, el escritor decidió poner en las manos de los lectores La antología del Zohar. Esta antología es una interesante recopilación del libro cumbre de la corriente kabalística. En una nota a la primera edición de esta antología, Barnatán revela que, para elaborar su antología, él prefirió "seguir las líneas maestras de la selección de Gershom Scholem” (Barnatán, La Kábala 6). 
Para los kabalistas (la Kábala como doctrina de la unidad), la realidad es un todo en el que lo evidente y lo dudable, lo tangible y lo inmaterial, se incluyen mutuamente y se unen.

El Laberinto de Sión se apoya en la hipótesis de que, tanto el narrador protagonista como el lector, rescatarán los dos juntos las riquezas de la cultura sefardita, particularmente la parte mística. El protagonista de esta novela intenta presentar esta cultura para que tenga un significado entre lectores de lengua española que están acostumbrados a leer la literatura contemporánea. Este es el único requisito necesario para poder entender su obra.

El texto hermético demanda un ejercicio de interpretación, pero su obra poética o narrativa vista, como comentario esotérico y kabalístico, no resuelve los problemas que su obra literaria crea. Para una buena comprensión de su primera novela, por ejemplo, no es necesario tener conocimientos básicos de la Kábala. Sin embargo, las manifestaciones del discurso en El Laberinto de Sión involucran nociones aceptadas del caudal del judaísmo: la devoción a la Torá ${ }^{2}$ y al lenguaje hebreo, y el respeto por los símbolos.

Por otra parte, la estética de Barnatán y la de los autores del Séfer Yetsirá, el Séfer ha Bahir y el Séfer ha Zohar comparten la idea de un pensamiento universal, un modelo o una doctrina filosófica-religiosa que ocasiona la impresión de estar observando o examinando constantemente nuestro proceder, o de ser la prolongación de un diseño mucho más grandioso y extenso. Esta cosmovisión o forma de concebir

\footnotetext{
${ }^{2}$ Se ha señalado que la Torá no solo es el texto del Pentateuco que Dios entregó a Moisés en el monte Sinaí, sino que también incluye un conjunto de enseñanzas orales que constituyen el núcleo de la tradición esotérica transmitida de generación en generación hasta la actualidad. Para los kabalistas, la Torá adquiere toda una serie de significados posteriores mucho más profundos que la simple dualidad de la transmisión escrita y oral.
} 
e interpretar el mundo nutre una concepción del acontecer tanto de los exégetas como de muchos escritores extraordinarios.

Este estudio explora la relación entre algunos de los textos del pensamiento místico sefardita y el discurso experimental de Marcos Ricardo Barnatán. La premisa es que ciertos textos místicos teosóficos sefarditas tienen ciertas características literarias que los convierten en una fuente fértil para literaturas posteriores, como es el caso de la obra del escritor ya citado.

Esta disertación probará que tanto la poesía como la primera novela de Marcos Ricardo Barnatán, El laberinto de Sión, pueden ser un vehículo útil con el cual se puede acceder a los conceptos más generales encerrados en la Kábala. Además, revelará hasta qué punto la primera novela y la obra poética de Barnatán están impregnadas con el simbolismo de las teorías cosmogónicas, así como con el estilo y espíritu de las obras kabalísticas.

La investigación busca demostrar que existe la posibilidad de leer los textos kabalísticos, tanto en el plano poético como en el exegético, y que la obra de Barnatán puede ser vista como algo más que un conjunto de experiencias inventadas, ya que al interior de ella late un compromiso.

Tanto los textos kabalísticos Séfer Yetsirá, Séfer ha Bahir y Séfer ha Zohar como la obra de Marcos Ricardo Barnatán están dirigidos a comunicar lo incomunicable, pues aparentemente están limitados por la barrera del lenguaje.

El objetivo de este trabajo es probar que tanto el pensamiento místico judío como la obra de Marcos Barnatán comparten una determinada visión del lenguaje, de la escritura y de la creación. Para ello, es preciso mencionar a críticos literarios y figuras destacadas como H. Bloom, G. Scholem, Heschel, Gadamer, Anderson, 
Fishel, Jauss, Pinjas, Madirolas, Knight, Tresoldi, M. Buber, y Moshe Idel, debido al valor de sus extensos trabajos investigativos.

En el primer capítulo se analizará el contexto literario y religioso que fomenta la germinación de la obra literaria, tanto poética como narrativa, de Marcos Ricardo Barnatán. En un principio se enmarcará al poeta dentro del grupo de los 'novísimos', dado que este posee criterios estéticos y éticos totalmente diferentes de los escritores de la posguerra. Sin pretender ser conclusivos en un tema tan amplio y de opiniones tan encontradas, se repasarán los factores más singulares que ubican a este escritor en aquel grupo de poetas que supo defender la autonomía del arte. El sello de Barnatán es su laboriosa intertextualidad y una cuidadosa elaboración retórica que hace que sus textos se perciban como herméticos. En el mismo capítulo se llegará a la conclusión de que Barnatán no pertenece al boom literario, como muchos piensan, pues se encuentra mucho más cercano a la problemática posmoderna.

Barnatán, a diferencia de los escritores del boom, pretende recuperar la sacralidad del arte, limitar el acceso a los iniciados y recuperar un espacio elitista literalmente hermético, además de otras características que subyacen en su obra, como el uso de la imbricación discursiva de estilos y la recuperación de símbolos, alegorías e imágenes. La fuente de inspiración fuerte de Barnatán, como ya vimos, son los libros básicos de la mística judía: Séfer Yetsirá, Séfer ha Bahir y Séfer ha Zohar. Por esa razón, todos ellos se analizarán brevemente con el fin de ayudar a entender con más profundidad la obra del poeta y novelista que ocupa este estudio. De este análisis se llegará, también, a la conclusión de que uno de los pilares más sólidos de la obra de Barnatán es su intertextualidad con los textos místicos, pues en ellos encuentra una valiosa fuente de alegorías y simbolismo. La investigación y el trabajo hecho por Barnatán sugieren una nueva lectura de los textos kabalísticos. Las ocultas nociones 
kabalísticas reveladas en la obra de Barnatán aportan una nueva perspectiva para los lectores modernos.

Este capítulo cerrará con un apartado donde se explica la razón por la cual Barnatán es un gran admirador de los maestros de la alegoría. Al no caer en la tentación de interpretar, Barnatán no comete errores: se limita a trasladar la representación abstracta cognoscible a conceptos cotidianos. En su obra, la aparente limitación del lenguaje se convierte en una posibilidad. A través de alegorías e imágenes, Barnatán muestra las limitaciones y los fracasos del hombre pero, al mismo tiempo, retrata sus potencialidades.

En el segundo capítulo su obra poética se analizará en detalle. Para ello, se ha tomado su poemario El oráculo invocado, donde el poeta compila todos sus libros poéticos. A partir de esos textos se analizarán algunos conceptos que la Kábala y la poesía tienen en común, tales como el Tsimtsum, la Nada, y lo Manifestado.

El primero (Tsimtsum) viene por la necesidad de un espacio fértil donde el artista pueda desarrollar su poética, que en la Kábala es un espacio fuera de Dios donde puede darse la Creación. Pero dado que Él todo lo ocupa, debió contraerse para que la Creación pudiese ser (Luria) ${ }^{3}$.

El segundo concepto es el de la Nada. Para el kabalista, esta no significa ausencia ni negación, sino robustez y energía máxima. Es ahí donde el poeta encuentra sosiego y libertad expresiva. En Barnatán, la Nada aparece como misterio y motivo de la acción. Considerar la literatura kabalística igual de válida que la del

\footnotetext{
${ }^{3}$ Rabi Isaac Luria Azhkenazi (1534 - 1572) fundador de la escuela kabalística de Safed. Está considerado como el pensador más profundo del misticismo judío. Sus discípulos lo consideraban como un santo, elohi, divino, término este no muy frecuente en el judaísmo. Prácticamente solo se aplica a él. Luria — o Ari, como lo conocían — convirtió la Kábala, de un método usado sólo para virtuosos, en un sistema accesible para toda persona en nuestra generación.
} 
escritor que nos ocupa no equivale a negar el hecho de que aquella fue concebida en el ámbito de lo sagrado. Ambas lecturas — salvando las diferencias - suponen un estar atento, con éxtasis y libertad, a todo el conjunto de valores y posibilidades que contienen sus textos. Este trabajo posee, en su esencia, el anhelo de reconquistar el legado del judaísmo hispánico y desea señalar la validez de su imaginario como paradigma de la exégesis práctica mística.

El tercer concepto, lo Manifestado, ocurre cuando el poeta desterrado abraza el universo de la palabra en su escritura y brota de él un poema que no aspira a persistir ni a colmar, pues se limita a ser un fruto que reiteradamente ha de reinventarse. Exactamente igual sucede con la Torá, objeto de estudio de las kabalistas. En esa incesante y siempre rejuvenecida Creación siempre debe haber espacio para dar a luz el renovado milagro del inicio. Más adelante se insistirá en el hecho de que en este ejercicio se benefician dos ámbitos del lector: el poético y el religioso. Barnatán sabe lo importante que es dar respuesta al vacío con una energía obstinada de interpretación, pero haciéndonos descubrir al mismo tiempo, mediante el uso de la vaguedad, las limitaciones de nuestro conocimiento. La obra de Barnatán define al ser humano como aquel que reconoce la desilusión y la amargura, pero que no desiste aprender a vivir de una forma diferente.

Al final de este capítulo se desarrollará un apartado sobre el lenguaje práctico cuando de lo inefable trata. Para Barnatán, la voz poética de los poemas ostenta una poderosa sabiduría que hace que ellos conformen una pieza dentro del sistema cultural al que ellos remiten.

En el tercer capítulo se analiza la narrativa de Marcos Ricardo Barnatán. Por razones de extensión, solo se ha tomado su primera novela: El laberinto de Sión, que además resulta mucho más apropiada para el tema analizado. Laberinto se estudia 
dentro del contexto teórico posmodernista. En este caso, los críticos literarios más consultados han sido Ihab Hassan, Brian McHale y Vattimo. Todo este capítulo busca probar que Barnatán hace notoria la idea de que la religión cae en el pecado cuando comienza a abogar por la segregación de Dios, olvidando que el verdadero santuario no tiene paredes. Por ello el autor, en su primera novela, rechaza los grandes modelos fijados y cerrados a la infinitud: la elección de espacios muy poco convencionales responde a su necesidad de presentarnos la multiculturalidad. El escritor encuentra en los libros religiosos — especialmente en la Torá — un tipo de texto polifónico que encaja muy bien dentro de su estética posmodernista.

Una vez desarrollados estos apartados acerca de la palabra revelada — siempre idéntica en la forma pero múltiple en el significado-, se analizará la responsabilidad que, para Barnatán, tiene el hombre ante el texto. En su obra existe una conciencia cosmopolita que excede los límites impuestos, algunas veces, por la razón humana.

De esta forma se llegará a la conclusión de que Marcos Ricardo Barnatán queda inscrito culturalmente en las tendencias artísticas contemporáneas. Su actitud polémica halla sus raíces fuera de su profesión de escritor: estas se encuentran en la naturaleza misma de la vida social e individual de nuestros días. Barnatán, entonces, reniega de las formas heredadas, vuelve su mirada al caos de las fuerzas primigenias del alma y se entrega a la aventura artística, hasta encontrar en la mística judía su pilar más fuerte.

Este poeta lleva con dignidad y plenitud semántica la representación de nuestro tiempo, ya que su obra muestra una íntima coherencia e identidad de fondo y experimenta, mediante grietas y desmoronamientos formales, rupturas con la tradición, imágenes como relámpagos superpuestos y truncados, y omnipresencia de la angustia metafísica. 
Marcos Ricardo Barnatán, al igual que los tres libros místicos básicos del judaísmo, crea un sorprendente andamiaje expresivo sin atadura alguna a modelos preestablecidos. Esta estructura expresiva, erigida por una vasta red de símbolos, se alimenta de la reivindicación de la libertad.

Convendría indagar, una vez concluido este estudio, en las interacciones entre los comentarios kabalísticos y el nuevo discurso contemporáneo, para precisar posteriormente si las similitudes artísticas o estéticas están apoyadas en esos caudales vastos y profundos del pensamiento. 


\section{CAPÍTULO 1}

\section{CONTEXTO RELIGIOSO-LITERARIO DE MARCOS RICARDO BARNATÁN. CARACTERÍSTICAS GENERALES DE SU OBRA}

La idea de un pensamiento universal cargado de pequeñas y heterogéneas porciones es el centro de la neurosis que nutre la ficción de Barnatán, convirtiéndose en tema ficticio. Ella provoca en el escritor un estímulo capaz de reestructurar todo su sistema expresivo.

Barnatán indaga sobre el origen y la esencia de la creatividad poética con relación al registro total de la lengua, razón esta que lo hace poseedor, junto a los místicos judíos de Provenza, de un cierto tipo de disposición — tenaz, además — por calibrar las metáforas, aquellas usados por escritores dentro de las más variadas culturas.

Barnatán —al igual que Jorge Luis Borges— es de la opinión que "la literatura hasta cierto punto considera y analiza, metafóricamente, los temas religiosos y filosóficos” (Barnatán, Biografía total 31). Barnatán adopta la idea que contempla la exteriorización de la incógnita a través del símbolo, tal como los kabalistas hicieron. Los místicos “establecieron un cuerpo alegórico que, además de representativo, fue capaz de revelar las reflexiones más recónditas del vínculo hombre - Dios” (Scholem, La Cábala y su simbolismo 66).

Al operar la materia mística, Barnatán no solo exhibe una inclinación por los símbolos kabalísticos sino que acredita, acepta y avala toda la lírica del cuerpo simbólico. El escritor es consciente de que la insinuación es idónea para penetrar dentro del texto y así concretar un aventajamiento ideológico sin que exista necesidad alguna de nombrarlo. Esto es posible gracias a que cada imagen kabalística propia forma parte de una estructura más espaciosa y es la clave para el todo. En el símbolo 
kabalístico, Barnatán advierte el atributo evocador estimulante y sugestivo que instiga, exhorta y vivifica la búsqueda del sentido.

Según el propio escritor, los kabalistas consideran que, como los símbolos no lo exponen todo (como sí hace la revelación directa o la plática lógica), ellos deben recurrir al rastreo, a la investigación que revele las sugerencias evocadas (Barnatán, Antología del Zohar 21). Es la dimensión insinuante e imaginaria de los símbolos "la que los hace importantes en el momento de lograr copiosas y fructuosas experiencias literarias en el lector" (Bloom, La Cábala y la crítica 81).

Así, los kabalistas sefarditas atestiguan que resulta mucho más conveniente y fecundo el recurso de insinuar las formas que el de explicarlas o definirlas. La insinuación y la alusión soslayada permiten discutir toda clase de contingencia; inducen o rehabilitan la imaginación, pero además, hacen creer al lector que fue él quien llegó al desenlace o a la conclusión y no el autor. Cuando se expone todo — ha llegado a plantear Barnatán— “el interés no se alienta ni se anima la interpretación investigativa, por lo que no se facilita la vivencia religiosa gratificante" (Barnatán, $L a$ Cábala y la crítica 65$)$.

Los místicos sefarditas tejieron la idea de que esa búsqueda, apoyada por el sistema simbólico, tiene una esencia religiosa, ya que las metáforas kabalísticas ambicionan ser ese portón al que Kafka hace referencia en El proceso. Este conduce a un viaje tanto existencial como espiritual. Barnatán, sin contradecir lo anterior, acentúa que este viaje posee un fondo metafísico, ya que en última instancia los símbolos perfilan el desarrollo y las dificultades del hombre.

Barnatán intenta laborar y vivir de acuerdo con el contenido indubitable del judaísmo y de los preceptos contenidos en la Torá. Como ya se ha mencionado, el autor se interesa por el uso metafórico de toda la mística, recurso este convincente y 
poderoso; sin embargo, elude todo tipo de material kabalístico serio en su primera novela, El laberinto de Sión, la cual ostenta un marcado interés por lo místico.

Otro hecho que llama la atención en su primera obra literaria es que no presenta en ella a la escritura hebrea; incluso las reproducciones del hebreo a la escritura castellana suceden pequeñísimas veces. En su primera novela, por ejemplo, el idioma francés, en cambio, es el que complementa al español, y aisladamente se puede encontrar ejemplo de ladino: "Jamais de la vie, greca yo... oh, no, soy espanyola, espanyola de Salónica... Oh, la Salónica, que tierras buenas, pero éstas la son más nosotros ya estamos viellos pero vos podes facer fortuna en esta tierra, vosotros los mancebos, los que están mancebos...”(82).

Llama también la atención que, en El laberinto de Sión, la Torá y sus comentarios son aludidos muy raras veces. El discernimiento kabalístico proveniente del escritor que nos ocupa tampoco está expresado de una forma clara. Incluso va más allá, ya que a pesar de dedicarle la novela a Gershom Scholem, en ningún momento se respalda en él o en otras autoridades prestigiosas del campo. La obra de Barnatán, sin embargo, no carece sino que está llena de alusiones metaliterarias y religiosas.

Barnatán imagina la prosa —incluso la poesía — como una exploración o un rastreo dentro del misterio que, al pretender discernirlo, sitúa al lector en el umbral del proceso creativo donde más tarde tendrá este una vivencia existencial y donde sentirá el latido de la exaltación y el enternecimiento. Barnatán hace uso, para tal fin, de un lenguaje denso, cargado de imágenes y de símbolos singulares, sin embargo su discurso mantiene una sintaxis lustrosa y cristalina. El discurso del novísimo poeta se caracteriza por exhibir vastas dosis de exquisitez y de elegancia.

La imagen en la obra de Barnatán es un componente de la realidad y del pensamiento, y Barnatán concede al lector la posibilidad de regenerarlas. El recelo 
sobre el testimonio que nos proporcionan nuestro discernimiento y nuestra indagación de lo ignorado, a partir de la imagen, sitúa al lector en una posición muy compleja.

Es esta la razón por la cual las conexiones de la metáfora son crecientes, sucesivas, graduales y hasta infinitas, como dice Lezama Lima en la entrevista concedida a Armando Álvarez Bravo. Según el notable escritor isleño, "la literatura constituye un conjunto o un cuerpo, un todo, que se encuentra interconectado con la dimensión metafísica, y es a través de la extraordinaria maquinaria llamada metáfora" (7). Junto a ese interés por discernir las lecturas es que surge el intenso empeño por la integración en la unidad, y es precisamente sobre este concepto que se edifica la obra de Barnatán.

La teoría de Harold Bloom es un instrumento importante para descifrar estos artilugios. Es cierto que Barnatán es manifiesto y categórico en esta intención y que sus textos lo hacen de manera encubierta a través de un cuerpo simbólico que se debe descifrar. Barnatán comparte el descubrimiento en el momento de la lectura, consumándose así la función hedónica. Ambos — autor y lector- lo vivencian tranquilamente en la reflexión y en el recogimiento subsiguiente. En la obra de Barnatán la temática no importa, sino el principio o el origen de las conexiones.

\subsection{LA KÁBALA DENTRO DEL DISCURSO CONTEMPORÁNEO Y URBANO: EL EJEMPLO DE MARCOS RICARDO BARNATÁN}

\subsubsection{Marcos Ricardo Barnatán dentro de los novísimos}

Las circunstancias sociales, económicas y políticas estaban cambiando a gran velocidad en toda Europa, y ya a finales de la década de 1960 se habían materializado algunas de ellas. Todos estos cambios hicieron posible que los lectores jóvenes y los escritores del momento se fascinaran por la poesía de vanguardia, que procuró 
ejercitar la innovación y la libertad de expresión. Una característica presente en estos jóvenes escritores y poetas fue la ruptura con la literatura comprometida y con el realismo social que se venía haciendo desde la década de 1940. La experimentación frenética del lenguaje fue una de las metas más marcadas por estos jóvenes, que solo conseguían entenderse a ellos mismos y que, según Scott Fitzgerald, en ocasiones ni siquiera eso. Por lo general, estos escritores solían mantener una actitud radical, de oposición a un régimen establecido en el que se confundían el franquismo, el totalitarismo soviético y el imperialismo norteamericano.

Se calcula, de manera bastante unánime, “que ya para finales de los años 60 y durante la década de 1970, ya se había dejado a un lado el realismo social en España y se había institucionalizado esta nueva estética (Castellet, Nueve novísimos 13).

La característica central de estos artistas es su postura resolutivamente antirrealista, que lejos de la noción del poema como entidad referida a la vida cotidiana, torna los ojos hacia la subjetividad poética y la simbolización. Esta condición demandaba, de partida, la codificación de un nuevo universo mítico que la generación joven formó con elementos provenientes del mundo literario, del pasado histórico (época alejandrina, Renacimiento, Romanticismo), de los clichés esteticistas (ciudades-símbolo como Venecia, monumentos, cuadros, etc.) o de la modernidad urbana (personajes del cómic, estrellas de cine, cultura de los medios de masa).

El semblante debilitado que mostraba dicha estética —en la superficie al menos - incitó la crítica de quienes, desde ópticas comprometidas, concibieron esta poesía como un producto neocapitalista. Ricardo Barnatán, con su trabajo literario, se suma a esta generación de poetas españoles que tienen criterios estéticos y éticos totalmente diferentes que los escritores de la posguerra. 
El artista de este periodo no estaba conforme con los movimientos culturales ni de una ni de otra orientación política. Tampoco con el presente que les tocó vivir, pues no les servían ni las estructuras establecidas literarias ni las sociales, y por esa razón necesitaban hacer cambios radicales, aunque fuese tan solo en el plano artístico.

Las reglas tradicionales de la poesía — sobre todo la versificación — limitaban las posibilidades de expresar el mundo de estos nuevos poetas, llamados "novísimos" por Castellet en su antología Nueve novísimos poetas españoles. Sin embargo, si la anterior estética pecó por un excesivo compromiso social, la de los novísimos falló por un insoportable hermetismo.

Los Nueve novísimos poetas españoles es un libro del crítico José María Castellet, publicado en Barcelona en 1970, en el cual reúne obras de los poetas que consideraba como los más renovadores de los años 1960. Marcos Ricardo Barnatán no se menciona en esta antología, pues empezó a publicar luego de esos años.

Este muestrario está dividido en dos secciones ${ }^{4}$ : la que corresponde a los que Castellet llama seniors, que comprende a Antonio Martínez Sarrión, Manuel Vázquez Montalbán y José María Álvarez, y la que incluye a los que se hallan bajo el término coqueluche, compuestos por Pere Gimferrer, Félix de Azúa, Vicente Molina Foix, Ana María Moix, Guillermo Carnero y Leopoldo María Panero. Dentro del grupo cohabitaban dos directrices: la vinculada con la estética de la contracultura y la culturalista.

Según el autor catalán, estos poetas se caracterizan "por una absoluta libertad formal; el recurso de la escritura automática y de técnicas elípticas, de sincopación y de collage; la introducción de elementos exóticos y de artificiosidad" (Castellet Nueve

\footnotetext{
${ }^{4}$ Para más información sobre esta división de autores, véase Castellet, Nueve novísimos poetas españoles, p. 45.
} 
novísimos 17); la influencia de los medios de comunicación y del cine. Su formación literaria era extranjera y cosmopolita, lo que supuso el rechazo de la tradición inmediata, con las excepciones de los españoles Vicente Aleixandre, Luis Cernuda y Jaime Gil de Biedma, y de los hispanoamericanos Octavio Paz, Oliverio Girondo o José Lezama Lima.

Algunos de los autores que también pertenecen a los novísimos, pero no ya al grupo de los seniors, son Luis Alberto de Cuenca, Antonio Carvajal, Marcos Ricardo Barnatán, Ramón Irigoyen, Antonio Colinas, Jaime Siles, Jenaro Talens y Jesús Munárriz.

Marcos Ricardo Barnatán comparte muchas más características con las segunda generación de los novísimos, ya que reacciona "rompiendo drásticamente con la métrica practicada hasta el momento y advierte en su poesía una profunda preocupación por el hombre y por su destino" (Oviedo, Historia de la literatura hispanoamericana: posmodernismo, vanguardia, regionalismo 32), además de su insistencia en el collage cultural.

Barnatán es muy peculiar dentro de los novísimos debido a la temática utilizada — como ya se ha mencionado - y por aplicar la técnica de collage surrealista y aproximarla a los conceptos místicos judíos de forma muy prudente. Lo que hace interesante y seductora la obra de Barnatán es que, donde nada parecía convenir o corresponder debido al aparente, ningún punto de conexión, de repente todo se vuelve un amasijo ya que todo en ella cuenta, y cada pieza cobra sentido con respecto a la otra. Culturas europeas modernas, concepciones kabalistas, textos seculares y religiosos, estos últimos sin ningún tipo de autoridad religiosa, fragmentos de canciones populares sefarditas, así como carteles publicitarios, están presentes y mezclados en su obra. 
Todos estos poetas comparten no solo las actitudes más destacadas de dicha estética, sino también "preferencias por los viajes, la música, el cine y la pintura contemporánea" (Castellet, Nueve novísimos 21). El poeta que nos ocupa constantemente viaja a Israel, Francia e Italia, además de sentir un gran interés por la pintura. En artículos publicados en el periódico español El Mundo hace derroche de su interés hacia las artes plásticas. En el artículo publicado el 11 de enero de 2010 en la edición impresa de El Mundo, a raíz de la muerte del escritor Kenneth Noland, Barnatán comenta sobre la vida y el trabajo plástico del pintor.

Era uno de los pintores norteamericanos más destacados del siglo XX; discípulo de Joseph Alberts, se significó por su abstracción geométrica, por sus círculos concéntricos de colores muy intensos. Tras participar en la Segunda Guerra Mundial en el ejército norteamericano, ingresó en el Black Mountain College, donde impartían clase exiliados del nazismo como Alberts, Gropius o de Kooning. [...] Una de las características de su trabajo era que pintaba sobre lienzos no preparados que absorbían el acrílico como un papel secante impregnado de color. También recurrió a la búsqueda de diferentes formas de las telas, superando el modelo rectangular, algo que lo llevó también a interesarse por la escultura, que realizó con la influencia de su amigo el inglés Sir Anthony Caro... Kenneth Noland era un hijo mayor de la gestualidad post surrealista, que muy pronto decidió que su pintura debía "organizarse", algo que vieron de inmediato tanto Rubin como Clement Greenberg. Tras aquel fiero automatismo, y por un proceso reductivo que los expresionistas abstractos norteamericanos supieron llevar al límite del paroxismo, el automatismo psíquico se convierte en automatismo físico: ese "a donde el brazo te lleve" que incursiona en lo hasta el momento desconocido hasta que se convierte en normal... Los discos concéntricos de los años cincuenta vuelven otra vez a finales del siglo XX, son el fruto de un feliz descubrimiento del pasado que vuelve, ahora describiendo nuevas variantes, marcadas por una repetición rítmica absolutista y obsesiva, que se regodea en las combinaciones de colores y afianza las formas hasta el infinito, sin perder nada de esa vertiginosidad giratoria del principio [...] (4).

Barnatán se identifica con la obra plástica de Kenneth Noland, ya que este sugiere en ella una "organización" que permite afianzar "las formas hasta el infinito". Barnatán señala que los discos concéntricos, muy presentes en su obra, no son más que una renovación artística de una estética de la década de 1950. "Es un 
descubrimiento del pasado" que, según el poeta novísimo, "vuelve”. Este pasado las formas antiguas - vuelven, pero para describir nuevas variantes para el hombre moderno.

Por este motivo, Barnatán defiende la necesidad de reorientar el discurso tanto poético como narrativo- hacia la creatividad, la novedad y el arte. El lenguaje en la obra de Marcos Ricardo Barnatán pasa a ser de univalente a independiente y arbitrario. Marcos Ricardo sabe que tiene que ser así, que no hay otra opción. En su libro La Kábala, el mismo autor comenta que:

El Creador y los hombres están para los kabalistas en un permanente diálogo, los Salmos recitados en los templos convocan su presencia protectora o misericordiosa, vengativa y terrible. El hombre increpa, reclama, se deja guiar por Él.

El sin nombre, sin Rostro, está en todas partes [...] Y el Creador, el Hacedor, el que hace: en definitiva el poeta dicta su alfabeto sagrado, sus veintidós letras esenciales, sus veintidós símbolos universales (63).

Llegados a este punto, se puede afirmar que la estética de Marcos Ricardo Barnatán se vuelca en una lírica que posee elementos relacionados con las vanguardias y donde se defiende la autonomía del arte. "La intertextualidad y la cuidadosa elaboración retórica hacen que muchos de sus textos se perciban como herméticos" (Anderson, Orígenes del posmodernismo 31). En muchos de sus poemas se mantiene "la estética urbana y la vida cotidiana, donde afloran sentimientos como el amor, la soledad y el paso del tiempo" (Lyon, Postmodernidad 28), características todas ellas que lo hacen pertenecer a la estética de los 'novísimos'.

\subsection{MARCOS RICARDO BARNATÁN: ENTRE LA MÍSTICA, EL POSTMODERNISMO Y EL BOOM}

Comparando los términos posmodernismo y misticismo, el autor acentúa que los dos son expresiones cuyo significado varía según sean utilizados. Si bien la discusión sobre el posmodernismo ha perdido su carácter polémico, aún sigue 
siendo discutido. La polémica reside sobre todo en esta diversidad, en esta heterogeneidad de puntos de vista. ¿Qué semblante significativo del posmodernismo puede servir como fundamento para el análisis del texto junto al misticismo?

"El posmodernismo parece representar cierta sensación de la sociedad contemporánea en la que se ponen en duda las tradiciones y los conceptos teleológicos que tratan dar un sentido a la vida humana" (Posada, 40 años de poesía española 23$)$.

El desvanecimiento de estas seguridades origina en muchas personas una búsqueda de otras alternativas competentes para dar un sentido a la propia existencia, puesto que, tanto la avidez de conocerse a uno mismo y de descubrir un lugar en este mundo como la pregunta ¿qué le pide Dios al hombre?, son, aun hoy en día, necesidades existenciales del ser humano. En este contexto, se observa también un resucitar de experiencias místicas. Sin embargo, ¿la mística es capaz de calmar esta necesidad? "Pareciera que la fe es una acto del hombre que al trascenderse a él mismo responde a Aquel que trasciende el mundo" (Heschel, Dios en busca del hombre 56).

Con la misma ligereza con la que se ha tratado muchas veces el término posmodernismo se han manejado también muchas definiciones sobre la mística judía. En diversas ocasiones se han referido a la mística con bastante imprecisión, aplicándole diferentes significados que implican, incluso, gran variedad de connotaciones desdeñosas. Ha sido acusada, según sus detractores ${ }^{5}$, por su escasa

\footnotetext{
${ }^{5}$ Véase Gerschom Scholem en La Cábala y su simbolismo: "pues cuando los judíos de la Europa occidental, en las postrimerías del siglo XVIII, tomaron tan decididamente el derrotero de la cultura europea, la Cábala fue una de las primeras y más importantes que cayeron. Entonces, se tuvo la sensación de que el mundo de la mística judía, con todo su contenido de simbolismo introvertido, era extraño y desagradable y fue relegado al olvido. Los kabalistas habían intentado sondear —o por lo
} 
transparencia y falta de contorno. De ella se ha dicho que es "irracional, retrógrada, y que en ella confluyen grades dosis de imprecisión y subjetivismo" (Moral, Joven poesía española 43), además de estar marcada por una anhelada tentativa de huir de este mundo. Sin embargo, no se desea recurrir aquí al carácter sedicioso de la mística que le es de por sí inherente. Más bien se intenta aclarar lo borroso de la mística para, de esta forma, pretender aclarar un poco más lo idiosincrásico de la obra de Barnatán.

La mística significa el empeño de experimentar a Dios mediante la contemplación, la meditación, el ejercicio del estudio y el cumplimiento de los preceptos y reglas. De lo que se trata es de reconocerse a uno mismo como parte del universo, de lo divino, pero para ello el hombre tiene que penetrar en la tradición oral que explica y fija el sentido de la Escritura.

Este hecho obliga a que el místico esté hondamente afincado en el sistema simbólico de la tradición religiosa correspondiente. En otras palabras, para que la experiencia mística pueda funcionar como un proceso recíproco, siempre es preciso:

[...] un punto de referencia religioso que luego forma el marco de símbolos e ideas convencionales, dentro del cual el místico intenta articular sus experiencias interpretando la [...] experiencia propia en una lengua, en imágenes y términos que se construyeron antes de él y para él (Scholem, El misticismo extraviado 32).

Esto trae a la mente la idea posestructuralista de que el lenguaje precede al individuo y que la formación del sujeto como tal se consigue solo después de inscribirse este al orden simbólico del lenguaje. Sin embargo, el lenguaje nunca

menos describir - el misterio del mundo como un reflejo de los misterios de la existencia divina misma, y sus imágenes en las que se condensaban sus experiencias se hallaban en estrecha relación con las experiencias históricas del pueblo judío, es decir, con las experiencias que en el siglo XIX parecían haber perdido su actualidad" (2-3). 
consiente formular el deseo verídico, concepto este que también encontramos en la mística. La dificultad de expresar o declamar la experiencia mística es incuestionable en este hablar místico que se caracteriza por la paradoja, la metonimia y la metáfora, entre otros recursos. Esta manera de referirse haciendo uso de metáforas y metonimias suena a la teoría lacaniana ${ }^{6}$, que considera necesario el desplazamiento del contenido del inconsciente, pues este desconoce otra forma de expresarse que no sea metafórica.

"El orden simbólico de la lengua precisa de un punto de referencia, de una jurisdicción" (Scholem, La Cábala y su simbolismo 43), y es por eso que en la obra de Barnatán se nos presenta esta autoridad en la palabra de Dios. La narrativa y la poesía de Barnatán señalan que la palabra de Dios se encuentra en cualquier lugar del espacio, y ya no solo en los textos sagrados. Y como el esfuerzo de la filosofía posmoderna radica en su estética para destronar cualquier autoridad y quitarle su carácter universal, hallamos, entonces, otro punto en común entre la mística y la teoría posmoderna.

En la obra de Barnatán, la comunicación mística es traducida en percepciones y comportamientos corporales que incluso pueden llegar a ser eróticos. No obstante, estos detalles revisten cierto vacío y se refieren al deseo verdadero del protagonista o de la voz poética: buscarse a sí mismo.

\footnotetext{
${ }^{6}$ Una de las incipientes hipótesis fuertes de Lacan es que lo inconsciente está constituido como un lenguaje, y este opera a través de los mismos procesos con los que se generan la metonimia y la metáfora. Lo que se viene a decir no es que se reduzca a un lenguaje. Por ejemplo, las imágenes oníricas son como metáforas de aspiraciones o deseos reprimidos. Según Lacan, la materialidad del pensar está dada por la materialidad de los significantes y por la combinatoria de significantes que configuran el pensar. Además de metáforas, el inconsciente estructurado como lenguaje se estructuraría en metonimias. Según la teoría lacaniana, una metáfora puede ser una condensación de metonimias. Para más información sobre el inconsciente estructurado lacaniano, véase Las formaciones del inconsciente.
} 
La voz poética de muchos de sus poemas, así como la voz del protagonista de su novela Laberinto, intentan trascender su propio yo para así experimentar la ansiada disociación entre su cuerpo y su yo. "La extrañeza de acercarse al yo a través del éxtasis corporal y la promesa de experimentar así la verdad de la existencia misma o la unidad ansiada lleva en sí rasgos místicos” (Lyon,

\section{Postmodernidad 61).}

Contrariamente a la comprensión esperada, en la obra de Barnatán se exhibe otra experiencia: la imposibilidad de poder encontrar el propio yo, el otro lado. Todas estas nociones obedecen a la búsqueda del paraíso perdido y al deseo de regresar a ese lugar que, según la premisa postmoderna, es imposible de alcanzar, ya que se niega el origen. Para el hombre de fe, ese lugar ${ }^{7}$ existe, está, y requiere nuestra participación llegar a él; sin embargo, es imposible alcanzarlo sin la participación divina.

En otras palabras, según plantean los partidarios del posmodernismo, no hay posibilidad de regresar, puesto que no existe ningún origen. Para otros, como Barnatán, esta es solo una verdad a medias. Mejor debería decirse que es imposible “por ahora”, ya que conforme al espíritu del judaísmo, la búsqueda de Dios es un retorno a Dios, es un intento de liberar la devoción reprimida. "Retornar a Dios es responderle" (7), plantea Abraham J. Heschel en Dios en busca del hombre, y ello solo será posible en la época del Mesías.

Por otra parte, Barnatán intenta — como ya se ha visto hasta aquíderrumbar cualquier tipo de autoridad discursiva referencial, pero los místicos están formados en su propia tradición, que posee un sistema de referencia concreto.

\footnotetext{
${ }^{7}$ Para más información véase: Conceptos básicos del judaísmo: Dios, Creación, Revelación, Tradición y Salvación de G. Scholem.
} 
Sin embargo, no es que este sistema sea totalmente rígido, ya que les da la oportunidad de transmutar los valores y las normas que forman su fundamento sociocultural: "Los valores antiguos, vistos con ojos nuevos, obtienen [...] un sentido nuevo" (17). Según G. Scholem, esto significa también que los valores antiguos perduran y que solo varía su significado, lo que viabiliza que sean aceptados dentro de su marco tradicional. Al mismo tiempo, se conserva la autoridad que se requiere como punto de referencia para alcanzar la elaboración de un nuevo significado.

Marcos Ricardo Barnatán no concede ninguna dinámica teleológica inédita e insólita, no ambiciona erigir un nuevo sistema de producción de sentido. Lo que ansía es deconstruir y contaminar esta autoridad, en lugar de crear. Ello posibilita no solo un cambio en el punto de vista con el que se suelen observar estas estéticas, sino que estimula que se pierda su sentido tradicional y, con ello, su supremacía. De este modo se establece una nueva forma de avistar los planteamientos, y a su vez es posible integrar en sus inclinaciones lo que se halla fuera de la propia experiencia, sobre todo si uno se abre a un proceso de innovaciones permanentes.

Otra particularidad de las maniobras místicas es "la posibilidad de establecer una autoridad nueva fundándose en la propia experiencia vivida" (Scholem, El misticismo extraviado 13), y esto es lo que se percibe en la obra de Barnatán. Él brinda otra doctrina, ya que no tiene el propósito de desplegar una nueva creencia. El texto, de hecho, no deja vislumbrar rasgos proféticos; por el contrario, la finalidad no es exponer respuestas sino promover la búsqueda: se pregunta, pero no se ofrecen respuestas.

La finalidad de la obra de Barnatán no es exhibir una experiencia mística que intente ser una forma diferente de percibir la vida sino "hacer del amor un 
agente entre el espíritu y el cuerpo, entre el texto y el conocimiento humano" (Scholem, Hay un misterio en el mundo 54), que en definitiva, según Barnatán, es entre el hombre y Dios.

Es el intento de reconciliar dos existencias que siempre han estado separadas. Esta retribución contrarresta, por tanto, el carácter irascible de las escenas transgresivas sobre los textos sagrados.

La obra de Barnatán sugiere que el deber del hombre en esta vida no es trascender el propio yo y que el discurso patriarcal no es la resolución con la que todo ha de medirse, sino "el propio ser es el que debe aceptarse, en su corta existencia, con todas las particularidades, e intentar trascender la naturaleza, la sociedad, los intereses y por qué no, los deseos" (Heschel, Dios en busca del hombre 15).

\subsubsection{Boom o posmodernismo en Marcos Ricardo Barnatán}

No se pretende agotar el amplio tema de la posmodernidad literaria; sin embargo, para los fines de este estudio es interesante destacar algunos rasgos esenciales de la estética posmodernista. De esta forma se evidenciará el vínculo que existe entre esta y la obra de Marcos Ricardo Barnatán, y más tarde, se llegará a la conclusión de que Barnatán no pertenece al boom literario.

Antes de hablar de las nociones de posmodernidad, conviene aclarar que Marcos Ricardo Barnatán se encuentra más cercano a la problemática posmoderna que a la del boom, como se intentará precisar más adelante.

Para el crítico literario Donald L. Shaw, lo que distingue el boom de lo posmoderno es, antes que nada, un asunto de contextos teóricos. Por ejemplo, Shaw no distingue entre el post boom y el posmodernismo (Shaw, La nueva narrativa 
hispanoamericana 31). Por su parte, Sklodowska ${ }^{8}$ no diferencia entre posmodernismo, post boom y novísimos. Oviedo ${ }^{9}$, mientras tanto, junto con el post boom, introduce el término posmodernidad periférica. Como se puede advertir, las cuestiones de periodización se relacionan con puntos de vista.

Según Raymond L. Williams, en su libro The Postmodern Novel in Latin America. Politics, Culture and the Crisis of the Truth, Joyce y Borges son los precursores de la posmodernidad latinoamericana, y Cortázar, Donoso y Fuentes representarían el eslabón entre la modernidad y la generación siguiente, que sería ya plenamente el posmodernismo.

Para llegar a la conclusión de que Barnatán no pertenece al boom literario, en lugar de ajustar el análisis a la controvertida y variada periodización expuesta, se tomarán en cuenta sus singularidades más preponderantes. Veremos que el posmodernismo, en contraste con el boom, pretende "recuperar la sacralidad del arte, [...] limitar su acceso a los iniciados [...], recuperar un espacio elitista literariamente hermético" (Oviedo, Historia de la literatura hispanoamericana: posmodernismo, vanguardia, regionalismo 56).

Eso es lo posmoderno: una imbricación discursiva de estilos tradicionales y nuevos, de formas lejanas y modernas, de eventos históricos y recientes. El posmodernismo es "una constante recuperación de mitologías, metáforas, símbolos, alegorías, imágenes, iconografías, entre otros” (Lyon, Postmodernidad 16). Pero, además de esta superposición, hay un dato curioso: se establece a través de todas las geografías y de todos los tiempos; no hay límites. Es una heterogeneidad cuya

\footnotetext{
${ }^{8}$ Véase, para más información, Testimonio hispanoamericano: historia, teoría, poética, de la misma autora.

${ }^{9}$ Véase, para más información, Historia de la literatura hispanoamericana: posmodernismo, vanguardia, regionalismo, de José. M. Oviedo.
} 
principal característica es "la polifonía de voces, donde se mezcla una gran variedad de géneros y de contenidos, y se aúnan elementos que antes parecían imposibles de combinar" (Anderson, Los orígenes de la postmodernidad 44).

En este sentido, la obra de Barnatán es completamente posmoderna. Cuando leemos, por ejemplo, su primera novela, nos encontramos ante un palimpsesto con textos diferentes y entremezclados, cuya conexión jamás queda completamente esclarecida.

Otra de las notas de la posmodernidad que Oviedo adscribe a las expresiones literarias más recientes y que pueden atribuirse a la obra de Barnatán es la presencia de "una incertidumbre constante que se trasmite en el propio quehacer narrativo y también que en ocasiones la trama da la impresión que las palabras ya no se refieren a los sucesos que los personajes sufren" (Oviedo, Historia de la literatura hispanoamericana: posmodernismo, vanguardia, regionalismo 112).

Por otra parte, la obra de Barnatán se caracteriza no por la ausencia de lo real sino por la saturación de ello. Es una especie de close up generado en la medida en que Barnatán explora de cerca un acontecimiento. A través de ensueños, recuerdos o figuraciones mentales de los personajes - e incluso del narrador - se logra este hiperrealismo en Barnatán.

El personaje de Barnatán es el hombre que se ahoga en la instantaneidad del hiperrealismo; sin embargo, en su obra hay una imposibilidad de aniquilar el futuro, y esto es posible gracias al intento de insertar una especie de éxtasis místico.

El hiperrealismo de Barnatán hace posible que su obra se conecte con otros rasgos posmodernos, como es el uso del pastiche, para lograr esa deseada y definitiva imbricación de estilos y temas que, como ya se ha mencionado, aparece en la obra posmoderna. 
Según Alfonso del Toro, la posmodernidad se entiende "como una actividad de recodificación iluminada, integrativa y pluralista que retoma y reconsidera un amplio paradigma, en especial de la cultura occidental" (Del Toro, Cartografías y estrategias de la postmodernidad y la postcolonialidad en Latinoamérica: hibrides y globalización 143), con la finalidad de repensar la tradición cultural y de esta forma, finalmente, abrir un nuevo paradigma donde se termine con los metadiscursos totalizantes y excluyentes.

El objetivo es colmar espacios aún vacíos que se encuentran entre los límites de la cultura establecida y la canonizada. En esta franja es donde podemos encasillar a Marcos Ricardo Barnatán.

Otra peculiaridad que Barnatán aspira a reactivar es la recuperación de ritos o discursos desaparecidos. Lo curioso del mencionado escritor es su insistencia en recuperar un discurso antiguo, ya sea a través del collage o mediante el uso del pastiche. Esa tentativa se puede percibir tanto en su narrativa como en su poesía, pues en ambas pone en entredicho todo el discurso racional moderno. Barnatán, en el exilio que dice encontrarse, trata de recuperar algún gran relato perdido en los siglos.

Frederic Jameson, en Postmodernidad y teorías culturales, se refiere a esta ansiedad del escritor posmoderno de la siguiente forma: "Como si por alguna razón hoy fuésemos incapaces de concentrarnos en nuestro propio presente, como si nos hubiésemos vuelto incapaces de conseguir representaciones estéticas de nuestra propia experiencia actual" (174). Barnatán revisa el discurso antiguo religioso e intenta conectarlo con las diatribas actuales; de esta forma, hace a uno menos preponderante, a pesar de su contemporaneidad, y al otro más actualizado, a pesar de su lejanía temporal. Barnatán sabe que la cuestión del ser humano es atemporal, además de universal. 
Otra peculiaridad de Marcos Ricardo Barnatán es que en su obra no manifiesta ningún tipo de compromiso sociopolítico, además de rechazar la tendencia de desconfiar del amor como soporte universal. Todo lo contario: su obra advierte en el amor "la única salida que tiene el hombre moderno para luchar contra esa soledad que lo azota además de confinarlo" (Heschel, Dios en busca del hombre 46).

En ningún momento Barnatán abandona los escenarios realistas por espacios imaginarios. Y este es un hecho que lo también lo aleja de las características del boom. Este escritor posee mayor seguridad respecto de la capacidad de percibir la realidad y confiere al lenguaje mayor confianza (capacidad referencial del lenguaje), lo que no sucede en la mayoría de los escritores del boom (basta recordar a Cortázar). Marcos Ricardo Barnatán, además, exhibe en toda su obra una actitud de respeto hacia la relación entre la alta cultura y la cultura de masas.

Por otra parte, y como consecuencia de todo lo que se ha venido comentando hasta aquí, en el sector temático se puede advertir un tratamiento más directo y simple de la realidad sociocultural, hecho que en los representantes del boom, como por ejemplo Gabriel García Márquez, es inimaginable.

\subsubsection{Insuficiencia del lenguaje}

Se ha dado por sentada una particularidad de Marcos Ricardo Barnatán que sería interesante ampliar. El tema de reflexión en la obra del escritor es precisamente la importancia del lenguaje. Aunque Barnatán muchas veces adjudica al lenguaje un carácter algo errático y problematiza la producción de sentido, sin embargo para él este nunca está ausente sino que se encuentra oculto. Según la mística judía, de la cual Barnatán es un estudioso implacable, el sentido se logra con el estudio de todas las indeterminaciones, lo que Scholem revalida diciendo que "el sentido se encuentra 
precisamente en el no saber, en la ambigüedad de la invención"' (Scholem, Los orígenes de la Cábala 72).

La idea de que lo dado en la lectura se ofrece como ilegible se debe, según algunos, a Jacques Derrida. En palabras de este crítico:

"[...] lo que se experimenta en el trabajo deconstructivo es que a menudo, no solamente en ciertos textos en particular, sino quizá en el límite de todo texto, hay un momento en que leer consiste en experimentar que el sentido no es accesible, que no hay un sentido escondido detrás de los signos, que el concepto tradicional de lectura no resiste ante la experiencia del texto, y en consecuencia, lo que se lee es una cierta ilegibilidad" (Espectros de Marx 68).

En un artículo publicado el 1986 en la revista Occidente, el mismo Derrida comenta que esta "ilegibilidad no es, ciertamente, una limitación exterior a lo legible, como si leyendo, uno se topara con una pared"; según Derrida, "es en la lectura donde la ilegibilidad se hace legible" (16).

La legibilidad, por ejemplo, de Laberinto se da en la medida en que sus personajes se ponen en movimiento, lo que a su vez echa a andar el juego de la ilegibilidad de la novela.

Esta es la razón por la cual, en ocasiones, el lenguaje es interpretado como desvío y no como una relación lógica. Al mismo tiempo, no sabotea la noción de significado sino que más bien inyecta un dinamismo radical. En la obra de Barnatán no solo se trata de reconocer la polisemia de un discurso, sino que el propio discurso, lejos de fijar momentáneamente un determinado significado, se convierte en un espacio de dispersión.

Marcos Ricardo Barnatán, con su obra, representa un intento de penetrar en el mundo subjetivo de la fuerza convencional de la palabra escrita y las técnicas narrativas. En la obra de Barnatán, el lenguaje, la escritura, no están para mostrar la dificultad del lenguaje (ello sería descabellado), sino para responder a ese 
inconveniente. Inmediatamente surge la pregunta: ¿cómo es que Marcos Ricardo Barnatán responde a esa imposibilidad, de la que se viene haciendo mención, del lenguaje en su obra? Lo logra imbricando planos: el novelesco o poético con el meditativo. Nunca los funde, ya que uno de los planos siempre interrumpe al otro, y en ese constante entorpecimiento donde se obstaculiza la participación del lector se logra una labor mucho más trabajada de representación.

Esta superposición de planos es consecuencia de la idea que abraza Barnatán sobre la escritura. Esta tiene que ser simulada, provocando en lo narrado una fragmentación. Y esa ruptura obedece a la imposibilidad de representar conceptos tan complejos como la identidad o la unidad y, al mismo tiempo, alcanzar una coherencia discursiva. Esta es la única forma que Barnatán encontró para poder descomponer las percepciones en instantáneas.

Barnatán solo ofrece en su discurso fragmentos, inscripciones con significados incompletos, letras con una gran variedad de simbolismo, mensajes a medias, además de textos difícilmente completados. Esta forma de Barnatán es la forma fracturada, "la forma del pastiche y la simulación, y esta no es más que la forma postmoderna" (Anderson, Los orígenes de la postmodernidad 77).

Una interrupción constante opera en su literatura, y esa es la causa más fuerte para que sea considerada como posmoderna: en ella no hay continuidad. Barnatán, incluso, es capaz de insinuar que "la historia de la humanidad es en la posmodernidad una ficción fragmentada ${ }^{10}$ e incompleta" (Lyon, Postmodernidad 33).

\footnotetext{
${ }^{10}$ El pensamiento posmoderno, al igual que para el místico, es fragmentado, sometido a una avalancha de información y estímulo difícil de estructurar, y es entonces cuando se opta por un vagabundeo incierto de unas ideas a otras. El posmoderno no se aferra a nada, no tiene certezas absolutas, nada le sorprende, y sus opiniones son susceptibles de modificaciones rápidas.
} 
Esta noción encaja perfectamente con uno de los conceptos más interesantes de la mística judía, y para resumirlo no citará la palabra de ningún erudito religioso sino del crítico literario Shaw: "El pasado puede ser reelaborado, el presente sigue temblando, subjetivamente en nuestras manos; el futuro lo podemos prever o desear, sin saber del todo cómo se nos va a revelar" (La nueva narrativa hispanoamericana, 113).

Aunque se puede decir que se ha venido pensando así, es en la posmodernidad donde se ha logrado el punto más alto de lo expresado, al "no haber ya discursos duros que legitimen un pasado o un proyecto de futuro" (Anderson, Los orígenes de la postmodernidad 57). Esta es la razón por la cual el suceso central de la obra de Barnatán siempre se está transformando, escabulléndose de un lugar para otro, y no se halla ni en el texto, ni en el discurso, ni en una figura humana. El acontecimiento que se nos escapa al leer a Barnatán puede ser todo o nada; puede ser interés de un momento y al siguiente instante transformarse.

Llegados a este punto, se puede concluir que Banatán expone de esta forma la panorámica siempre truncada, fragmentada, lo cual impide al lector elaborar un discurso coherente que articule el poema o la novela de principio a fin. El lector está imposibilitado de acceder a ese acontecimiento mitad mística, mitad escritura. La literatura, al igual que la mística, busca dentro de lo posible alguna forma para responder a lo imposible.

\subsubsection{Fin de los binomios}

Barnatán permite el exterminio de las dicotomías en su obra. Gracias a la metalepsis, se da la impresión de asistir a la neutralización de un binomio: el de la realidad y la ficción. En Laberinto, y en gran medida en toda la obra poética de 
Barnatán, se pueden encontrar, bajo la forma de pastiche, dos alusiones a escrituras que se oponen: la mística poética, que se asocia a lo oriental, y la escritura tradicional, asociada a lo occidental. En Barnatán es notorio que dichas corrientes, en apariencia contrarias, se unen de tal forma que logran disolverse entre ellas.

Barnatán trabaja con las polaridades y recrea como acontecimientos posibles ambas corrientes; es decir que no tienen que ser alternativas incompatibles y adversarias necesariamente, y es esta la razón por la cual sus personajes dan la impresión de estar fuera de toda disyuntiva religiosa o moral. Sus héroes protagonistas están más allá del bien y el mal; en el contexto de su obra, la polaridad no tiene sentido. Esta peculiaridad nos lleva nuevamente a pensar en el posmodernismo. La antigua dialéctica de binomios que alimentaba la literatura testimonial o de compromiso social se parece mucho a todos aquellos ideales que han muerto, por desembocar a la neutralidad.

Llegados a este punto, se puede señalar que, aunque en la obra de Marcos Ricardo Barnatán se encuentren algunas características del boom, él les da otro tono que modifica la perspectiva. Innegablemente se llega a la conclusión de que su obra está cargada de muchas más peculiaridades de la estética posmodernista; por tanto, es posmodernista.

De todas formas se hace necesario aclarar que no tiene sentido hablar de un escritor cien por ciento modernista ${ }^{11}$ o completamente posmodernista ${ }^{12}$, porque se sabe que absolutizar este tipo de aseveraciones es una falacia.

\footnotetext{
${ }^{11}$ Véase La modernidad y su desencanto, de Felipe Arocena. Vintén: Montevideo, 1991.

${ }^{12}$ Véase, para más información, Los orígenes de la postmodernidad, de Anderson.
} 
A modo de conclusión, se puede simplificar planteando que en la estética de Barnatán no existe un marcado compromiso sociopolítico; el amor es un punto importante en su obra por ser la única salida que, para él, tiene el hombre; no se abandonan los espacios realistas por imaginarios, y además, hay el intento de llenar los espacios vacíos que existen entre la cultura de masas y la canonizada. En Barnatán se perciben la realidad y el lenguaje con mucha mayor confianza. También se reconoce la cultura de masas, pero claro, imbricándola con la alta cultura. Y, por último, otro hecho que lo hace diferenciarse de los escritores del boom es el tratamiento directo y simple con el que se acerca a la realidad, además de arriesgarse con la neutralidad en la escena.

\subsection{TRES LIBROS MÍSTICOS: SÉFER YETSIRÁ (EL LIBRO DE LA CREACIÓN), SÉFER HA BAHIR (EL LIBRO DE LA CLARIDAD) Y SÉFER HA ZOHAR (EL LIBRO DEL ESPLENDOR)}

Indudablemente, Marcos Ricardo Barnatán es uno de los escritores más sólidos y reveladores de la literatura contemporánea. Su trasfondo personal y cultural le facilita el acceso a diversas fuentes judías, incluida la Kábala. Muchas de sus percepciones kabalísticas se vieron influidas por Gershom Scholem, quien popularizó gran cantidad de libros místicos que hasta ese momento estaban reservados solo para los eruditos en la materia.

En este trabajo se encontrarán referencias a las tradiciones antiguas Séfer Yetsirá, a las medievales Séfer ha Bahir, y al Séfer ha Zohar, que corresponde a las tradiciones hebreas del siglo XVI (Luria), hasta llegar al hebraísmo moderno y contemporáneo de Gershom Scholem, razón esta que obliga a una digresión. 
El texto del Séfer Yetsirá ${ }^{13}$ (Libro de la Creación) es en extremo breve. Pero a pesar de su brevedad, ocupa un lugar muy importante en la historia del pensamiento judío. Se han atribuido distintas fechas a su composición; es decir, a su manifestación escrita. Scholem cree que "su composición data de una fecha entre el siglo III y el IV de la era común. Otros historiadores creen que fue escrito cuatro siglos más tarde” (citado por Leon Dujovne en el prólogo de Kabbala Séfer Yetsirá: el libro de la Creación, 7).

En el examen del desarrollo místico judío se plantea el problema de la relación entre el Libro de la Creación y la Kábala. Los kabalistas suelen invocar como antecedente de su doctrina al libro que no estamos refiriendo.

Para Gershom Scholem, “el Séfer Yetsirá es un ensayo teórico sobre los problemas de cosmogonía y de cosmología” (citado por Leon Dujovne en el prólogo de Kabbala Séfer Yetsirá: el Libro de la Creación 7).

Según Mayer Lambert ${ }^{14}$, el Séfer Yetsirá no tiene nada en común con la Kábala. En efecto, por la palabra Kábala se entienden dos cosas: una explicación misteriosa de la Torá extraída de las mismas letras de su texto, y una teoría metafísica

\footnotetext{
${ }^{13}$ El primer capítulo, que puede ser considerado como una introducción, establece un paralelo entre el mundo y los números y entre las facultades de los hombres y las letras. El segundo capítulo trata especialmente de las relaciones del mundo con las letras. El tercero se ocupa de las propiedades de las letras y explica los nombres divinos. El cuarto es un ensayo de cosmogonía; hasta cierto punto es el desarrollo del primer párrafo del Génesis. El quinto capitulo detalla las producciones de las letras principales y dobles en el mundo, el tiempo y el hombre. El capítulo sexto es la continuación para las letras simples. El capítulo séptimo es un resumen de los dos capítulos precedentes. Finalmente, el octavo retoma retoma el mismo tema y agrega lo que hay en los primeros capítulos y también el epílogo.

${ }^{14}$ Rabino y orientalista francés, especialista en lengua árabe y filología hebrea. Publicó durante toda su vida una gran variedad de libros.
} 
que relaciona a Dios con el mundo por medio de una serie de emanaciones ${ }^{15}$ de la Divinidad. Nada semejante se encuentra en el Séfer Yetsirá, que se limita "a explicar la creación mostrando las distintas relaciones del mundo, del tiempo, del hombre con la numeración decimal y las divisiones de las letras del alfabeto" (Madirolas, El camino del árbol de la vida 131). Los kabalistas han tomado el Séfer Yetsirá como material base para sus estudios y han extraído de él ciertos términos que luego desarrollarán y ampliarán.

Sería un error, por ejemplo, proceder en sentido inverso y querer encontrar el Séfer ha Zohar en el Séfer Yetsirá, pues este al igual que el Zohar, constituye una parte de la magnífica ciencia denominada la Kábala. El autor del Séfer Yetsirá expone sus ideas de una forma concisa, mezclándolas con pensamientos ingeniosos y morales, lo que da como resultado una obra que demanda un profundo análisis. Por ejemplo, "las letras alef, mem, shin dan seis combinaciones: tres referentes al principio masculino y tres referentes al principio femenino, sin que se sepa por qué cada combinación se refiere a uno de ellos y no al contrario" (Tresoldi, La Cábala $32)$.

El autor del Séfer Yetsirá ha procurado hacer una obra tan interesante como profunda y tan moral como filosófica. Finalmente, hay que hacer notar que el Séfer Yetsirá se relaciona estrechamente con los textos bíblicos que tratan de la creación.

\footnotetext{
${ }^{15}$ El misticismo judío surgió para desarrollar una elevada y sutil concepción de Dios y su relación con el mundo y el proceso de la Creación. En el curso del desarrollo surgió la idea de la emanación de las fuerzas a partir de la divinidad, pero se hizo necesario usar la prevalente teoría de los ángeles y otras creencias similares. Para hacer más inteligibles sus enseñanzas, se emplearon expresiones simbólicas tomadas de estas concepciones. Con el tiempo, los símbolos se hicieron más prominentes que las ideas que debían expresar. Y, por último, los ángeles, las letras y sus variadas combinaciones comenzaron a adquirir una existencia independiente.
} 
El Séfer Yetsirán ${ }^{16}$ dejó una profunda impresión en la tradición kabalística y ha sido ampliamente interpretado. La premisa del Séfer Yetsirá es la misma que la noción bíblica de que el mundo fue creado con palabras y a través de un discurso. Este concepto hace que el discurso se desmonte en palabras y, a su vez, estas últimas en sus componentes fundamentales: las letras.

A través de este proceso de desmontaje es que se explican las combinaciones significativas del alfabeto hebreo. Si el lector no es consciente de que la discusión que trata el Séfer Yetsirá se refiere al mundo real, fácilmente puede relacionarlo con el mundo de la literatura. Es eso, precisamente, lo que hace Barnatán. La discusión que el Séfer Yetsirá emprende acerca de "los varios caminos y sistemas a través de los cuales el mundo fue creado" (Barnatán, Antología del Zohar 12) se parece mucho al arte poético manifiesto en toda la obra de Barnatán.

Otro libro místico notable es el Séfer ha Bahir, que significa Libro de la Claridad. También es conocido como el Midrash del rabino Ben Nehunya ben ha Kaná $^{17}$. Parece que fue publicado por primera vez en el siglo XII, en el sur de Francia. Entre los kabalistas medievales se hizo conocido como el Séfer ha Bahir (Libro de la Claridad ) debido a su comentario de apertura, un verso que dice: "Y ahora los hombres no ven la luz que es brillante en los cielos" (Job 37: 21).

\footnotetext{
${ }^{16}$ Información relativa a la literatura sobre el Séfer Yetsirá se encuentra en el erudito estudio que Castelli dedicó a esta obra en la introducción al comentario de Sabatai Donolo (Florencia, 1880).

${ }^{17}$ Este texto, según la tradición, lo escribió Nejunya ben ha Kaná en el siglo I d.C. Sin embargo, la mayor parte de las investigaciones modernas cree que se compuso en Provenza en el siglo XII. Su importancia radica en que trata del misticismo de las letras y alude a la doctrina de las sefirot. Gran parte de la terminología de esta obra llegó a formar parte del vocabulario de la Kábala; además, contiene una referencia a la creencia en la metempsícosis.
} 
Los kabalistas medievales escriben que el Bahir $^{18}$ no llegó a ellos como un libro unificado, sino más bien por piezas encontradas en pergaminos esparcidos y folletos. La naturaleza dispersa y fragmentaria del texto del Bahir, que a veces termina la discusión en medio de una frase y que a menudo salta al azar de un tema a otro, apoya esta afirmación.

El Bahir, entonces, carece de un principio organizativo y, por tanto, de una estructura literaria. En esta obra, todo parece haber sido mezclado al azar. El Bahir emplea una terminología mística muy peculiar para interpretar los pasajes bíblicos, mostrando, como es de suponer, preferencia por lo de naturaleza cósmica y cosmólogica. Además de ser un texto fragmentario, debe sumarse que el lenguaje es enmarañado y ambiguo, ya que la sintaxis en muchos de sus pasajes es casi incomprensible. El Bahir es un texto que comenta la Torá, el Talmud y la Aggadá. Se presume que los redactores del Bahir conocían ya el símbolo de la última sefirá como Guardián de Israel (salmo 121, 4) que, al igual que la Sabiduría en la Torá y la Shejiná en el Talmud, desciende sobre los seres terrenales.

El Bahir contiene comentarios que explican el significado místico de los versículos bíblicos, el significado místico de las formas de las letras hebreas, “el significado místico de los signos de entonación y los puntos de vocal en las letras, el significado místico de los estados en el Séfer Yetsirá (Libro de la Creación), y el uso de nombres sagrados en la magia" (Tresoldi, La Cábala 56).

Hay doscientos párrafos como aforismo. Cada párrafo utiliza referencias de la Torá para ampliar su presentación. Al igual que con todos los textos kabalísticos, los

\footnotetext{
${ }^{18}$ Uno de los manuscritos más precisos de la forma final del Séfer ha Bahir fue escrito en 1331 por Meir ben Salomón Abi Sahuquillo; su comentario sobre el Bahir se publicó de forma anónima como $O$ ha Ganuz (La Luz Oculta). Ha sido traducido al alemán por Gershom Scholem (1923) y al inglés por Aryeh Kaplan.
} 
significados son muy simbólicos y dan numerosas oportunidades para la interpretación. Una analogía común se utiliza en todo: un rey, sus siervos, su hija y sus jardines se usan para explicar el significado, en primer lugar de la Torá, y a continuación, en general, del tema principal del texto.

Es curioso advertir que la palabra hebrea sefirot fue descrita por primera vez en el Séfer Yetsirá como correspondiente a los diez números base y no posee el sentido que los kabalistas le dieron más adelante. Es en el Bahir donde se advierte con la primera discusión del concepto kabalístico de sefirot como atributos divinos y poderes que emanan de Dios.

El mundo, según el Bahir, "no es el producto de un acto de creación” (Knight, Simbolismo cabalístico 24). Al igual que Dios, “este existe desde toda la eternidad, no solo en potencia, sino en realidad, y la creación consistió simplemente en darle apariencia a lo que estaba latente en la primera sefirá como se llama, Elyon Keter, que emanaba de Dios" (13).

Esta sefirá dio a luz a Hokmah (Sabiduría), de la que emanaba Binah (Inteligencia). De estos tras, que son las sefirot superiores, y de los principios fundamentales del Universo, emanaban, una tras otra, las siete sefirot inferiores de las que todos los seres materiales están formados. Las diez sefirot están vinculadas la una con la otra y son la energía de Dios, las formas en que manifiesta su ser mismo.

Y por último, el Zohar, por ejemplo, es un texto rico, y no solamente un libro de interpretación de la Torá o un volumen teosófico, sino que es una obra significativa y sobresaliente de la literatura. "El trabajo se fracciona en diferentes tratados y examina los textos bíblicos para sacar de ellos su alcance máximo y oculto" (Barrylko, Filosofía judía 23). Según esta obra, el Universo se disemina entre las 
dominaciones de la luz y las tinieblas, y cada uno de los gobiernos está integrado por diez esferas.

Si bien la opinión de la mayoría religiosa en el judaísmo tradicional ha sido que "las enseñanzas de la Kabalá fueron reveladas por Dios a personajes bíblicos como Abraham o Moisés y fueron transmitidas oralmente de la época bíblica hasta su redacción por Shimon ben Iojai” (Knight, Simbolismo kabalístico 38), el análisis académico moderno del Zohar, realizado por el historiador de las religiones Gershom Scholem, ha teorizado que Moisés de León ${ }^{19}$ fue el autor real.

En el artículo de la Enciclopedia judaica, escrito por el fallecido profesor Gershom Scholem, de la Universidad Hebrea de Jerusalén, hay un amplio debate sobre las fuentes citadas en el Zohar. Scholem advirtió que el autor del Zohar basó su obra en una amplia variedad de fuentes judías ya existentes, mientras que al mismo tiempo creó una serie de obras ficticias a las que el Zohar hace referencia, como el Sifra Adam, el Sifra de Hanokh, el Sifra di Shelomo Malka, el Sifra de Rav Hamnuna Sava, el Sifra de Rav Yeiva Sava, el Sifra de Aggadeta, la Raza de Razin y muchos otros.

El Zohar está enmarcado por una historia muy peculiar. De un lado a otro de la Tierra Sagrada, un grupo de alumnos y su maestro estudian la Torá. La narrativa incluye encuentros del grupo con diferentes personajes que nunca son lo que parecen y que se convierten en una importante fuente de secretos revelados. Las interpretaciones de la Torá son expresadas en diversos géneros: parábolas, sueños, cuentos, entre otros.

\footnotetext{
${ }^{19}$ Véase, para más información sobre las razones por las cuales Scholem cree que Moisés de León es el autor del Zohar, Desarrollo histórico e ideas básicas de la Cábala.
} 
Las abundantes metáforas y símiles que se desempeñan como símbolos

kabalísticos pueden ser percibidos como símbolos poéticos. Por esta razón, Gershom

Scholem plantea que "el Zohar es como una novela metafísica" (Scholem Desarrollo

histórico e ideas básicas de la Cábala 55).

Por otra parte, el Zohar contiene una discusión sobre la naturaleza de Dios, "el origen y estructura del Universo, la naturaleza de las almas, la redención, la relación del Ego a la oscuridad y el 'verdadero yo' con la 'Luz de Dios', así como la relación entre la energía universal y el hombre" (Scholem, Desarrollo histórico e ideas básicas de la Cábala 31). Una gran variedad de estudios académicos sobre el Zohar muestra que muchas de sus ideas se basan en el Talmud, en varias obras de Midrash $^{20}$ y que además trabaja sobre la mística judía anterior. Sobre ello, en Jewish Gnosticism, Merkabah Mysticism, and the Talmudic Tradition, Scholem escribió:

The writer had expert knowledge of the early material and he often used it as a foundation for his expositions, putting into it variations of his own. His main sources were the Babylonian Talmud, the complete Midrash Rabbah, the Midrash Tanhuma, and the two Pesiktot (Pesikta De-Rav Kahana or Pesikta Rabbati), the Midrash on Psalms, the Pirkei de-Rabbi Eliezer, and the Targum Onkelos. Generally speaking they are not quoted exactly, but translated into the peculiar style of the Zohar and summarized (201).

No cabe la menor duda de que el autor del Zohar se basó en los comentarios de la Torá escritos por rabinos medievales como Rashi, Abraham ibn Ezra, Kimhi David, e incluso de las autoridades que llegaron más tarde, como Najmánides y

\footnotetext{
${ }^{20}$ Midrash es el nombre dado a las colecciones de algunos de los escritos que se ordenan en torno a la disposición del Tanaj (son los veinticuatro libros de la Torá). El Midrash se distingue por la gran cantidad de Aggadá que contiene. Aggadá es el nombre dado a un cierto tipo de escritura (historia, leyenda, alegoría, observación científica o similar). La palabra Midrash proviene de la forma darash, raíz hebrea, que significa "buscar" o "investigar". El Midrash, a través de un examen minucioso, intenta lograr una mejor interpretación del Tanaj para llevar a cabo el significado más profundo o ética del texto. Hay muchas colecciones diferentes del Midrash. La colección más grande se llama Midrash Rabá ("Midrash Grande").
} 
Maimónides. Scholem ofrece una variedad de ejemplos de estos préstamos $^{21}$, pero si los mencionáramos aquí se dilataría mucho este resumen. Básicamente se puede afirmar que el Zohar se basa en principios de textos místicos, como el Séfer Yetsirá y el Bahir.

De acuerdo con el Zohar, el perfeccionamiento moral del hombre influye en el mundo ideal de las sefirot; solo él puede lograr la efusión divina. Este concepto es algo parecido al de tikún olam ${ }^{22}$. El rocío que vivifica el Universo fluye de los justos. Con la práctica de la virtud y la perfección moral, el hombre puede aumentar la efusión de la gracia celestial. La vida física está subordinada a la virtud según el $Z_{\text {Zhar }}{ }^{23}$. Sin embargo, indica además que, en las palabras "porque el Señor Dios no había hecho llover" (Génesis 2: 5), lo que realmente se manifiesta es que, si aún no se había logrado una acción benéfica en el cielo, es porque el hombre todavía no había sido creado para orar por ello.

Los poetas religiosos no solo utilizaban las alegorías y el simbolismo del Zohar en sus composiciones, sino que incluso también adoptaron su estilo; por ejemplo, el uso de la terminología erótica para ilustrar las relaciones entre el hombre y Dios.

\footnotetext{
${ }^{21}$ Véase Gershom Scholem, Los orígenes de la Cábala.

22 Tikún olam significa reparar el mundo. Esta práctica debe ser seguida no solamente porque la Ley (judía) lo exige, sino porque ayuda a evadir consecuencias sociales negativas. Según el misticismo judío, la Creación del Universo está representada de manera figurada como un recipiente que no pudo contener la Luz Sagrada y se rompió en pedazos (shevirat hakelim). Por ello, de acuerdo con los kabalistas, el Universo donde nos encontramos está literalmente fracturado y precisa reparación. En consecuencia, siguiendo la Halajá (ley religiosa judía) y cumpliendo mitzvot (preceptos), el hombre ayuda a reparar el recipiente del Universo. Así, los kabalistas enseñan que, a través de sus acciones, cada ser humano puede participar en el tikún olam, literalmente reparando a la Humanidad y el Universo.

23 De acuerdo con la Enciclopedia judía, el Zohar incluso fue censurado por muchos rabinos, porque propagaba muchas creencias superficiales, y por una gran cantidad de soñadores místicos. La imaginación sobreexcitada de este ejemplar pobló el mundo de espíritus, demonios y todo tipo de buenas y malas influencias. El rabino Maimónides vio este tipo de creencias como una violación de los principios de fe del judaísmo.
} 
Para concluir, se puede llegar a afirmar que el Sefer Yetsirá (Libro de la Formación) es “el texto principal del esoterismo hebreo y se considera el libro más adecuado para los que inician el estudio de la Kábala" (Idel, La kábala y su interpretación 62).

El Séfer ha Bahir (Libro de la Claridad) es el segundo texto más importante de la historia de la Kábala. Representa un estadio de la Kábala más evolucionado y tiene algunas particularidades que hacen pensar en tendencias gnósticas de la tradición hebrea. El Bahir es un libro de cierto valor literario, ya que inicia, según Harold Bloom en La Cábala y la crítica, "el estilo kabalístico de la parábola y del lenguaje figurativo" (25). Su principal figuración reside en las sefirot, atributos de Dios que emanan de un infinito centro hacia toda posible circunferencia finita.

El Zohar, por su parte, es una de las obras más interpretadas de la kábala hebrea. El Zohar es un comentario de la Torá en formas de discursos de maestros de los primeros siglos de la era común.

Se puede concluir que los tres libros, en palabras de Scholem, son un intento de "pasar a un estadio posterior de la religión" (Grandes tendencias de la mística judía 89), ya que el hombre siente una alineación respecto del mundo que habita, cuando en él se distingue un vacío en el que "Dios se percibe como algo alejado, al otro lado del abismo que separa lo divino de lo humano" (Heschel, Dios en busca del hombre 77). 


\subsection{LA INTERTEXTUALIDAD ARTÍSTICA EN LA OBRA DE MARCOS RICARDO BARNATÁN}

En el campo de la crítica literaria, Harold Bloom ha llevado a cabo una utilización espectacular de los tropos. Lo especial que hay en la teoría de Bloom es la combinación que hace de la teoría de los tropos, la psicología freudiana y del misticismo kabalísticos.

En La Cábala y la crítica, Bloom afirma que "los poemas han sufrido "la conciencia de su atraso de haber llegado tarde a la historia de la poesía y que temen que sus padres poéticos ya hayan usado toda la inspiración disponible" (44). Es esta la razón por la cual experimentan contra ellos un odio al estilo de Edipo y sienten un desesperado deseo de negar la paternidad.

Según Bloom, estos sentimientos agresivos dan lugar a varias estrategias de defensa. Ningún poema se mantiene solo: siempre está relacionado con otro. Para escribir a pesar del atraso, los poetas deben iniciar una lucha psíquica para crear un espacio imaginario. Ello implica realizar malas lecturas ${ }^{24}$ de sus padres con el fin de llevar a cabo una nueva interpretación. Este encubrimiento poético produce el espacio necesario en el que pueden comunicar su auténtica inspiración. Sin esta agresiva desvirtuación del sentido de sus predecesores, la tradición ahogaría toda creatividad.

Por otra parte, las obras kabalísticas (los textos que intentan revelar los sentidos ocultos de los libros sagrados) constituyen, siempre según Bloom, el ejemplo clásico de textos revisionistas. Bloom cree que el misticismo kabalístico de Isaac Luria (siglo XVI) es un modelo ejemplar del modo en que el poeta revisa a sus

\footnotetext{
24 Bloom defiende la concepción estética de la literatura, renegando contra todo tipo de estudios culturales y materialistas. También han generado controversia sus particulares visiones sobre la religión: sugiere que la figura de Dios fue inventada en el plano literario por una mujer. Además cuestionó los conceptos de tradición e influencia con su definición de la "ansiedad de la influencia", explicando la creación literaria como una especie de pugna entre el escritor y los escritores que lo preceden y que forman parte de la tradición.
} 
antecesores. En La Cábala y la crítica, Bloom desarrolla tres etapas de la revisión de Luria: limitación (examinando de nuevo el texto), sustitución (reemplazando una forma por otra) y representación (restaurando un sentido).

Cuando un poeta fuerte escribe, pasa repetidamente por las tres etapas de modo dialéctico a la vez que lucha cuerpo a cuerpo con los poetas fuertes del pasado. Bloom es capaz de establecer seis palabras para describir las seis clases de relación entre los textos de los padres y los de los hijos. Sería conveniente estudiar la tercera parte de A Map of Misreading para comprender el alcance del método de Bloom.

En La cábala y la crítica, Bloom afirma que el significado, ya sea en la poesía moderna o en la Kábala, se lanza a errar cada vez que amenaza con apoderarse del universo verbal. El significado se extravía, se esparce en sus comentarios, deja desocupado su lugar, se arroja para más tarde exaltarse, resurge con la tenue perspectiva de introducirse más adentro. "Las imágenes de un poema o las hipóstasis de la Kábala son, por lo tanto, tipos de ambivalencia (no de ambigüedad) que se las tienen que entender con la carga de lo anterior" (Bloom, Los vasos rotos 14).

Por otra parte, como el arte poético puede referirse a los dispositivos del metalenguaje — que en las décadas pasadas solo aludía a las técnicas de la retórica incluida, pero no limitada a la escritura sobre la escritura y al pensamiento sobre el pensamiento-, Barnatán utiliza ampliamente este artilugio en aras de mejorar las imágenes, el entendimiento y la profundidad.

Esta investigación apunta hacia el entendimiento del arte poético manifiesto en toda la obra de Barnatán, como también sugiere una nueva lectura de los textos kabalísticos. En este trabajo se sostiene que la lectura intertextual posibilita una comprensión que va en ambos caminos. Las ocultas nociones kabalísticas reveladas 
en la obra de Barnatán aportan una nueva perspectiva, y es porque tanto su prosa como su poesía están infundidas de elementos y símbolos kabalísticos.

La intertextualidad artística atraviesa diferentes géneros poéticos. Su narrativa permite el desarrollo del simbolismo kabalístico dentro de una estructura textual profunda. Del mismo modo que las historias del rabino Nachman ${ }^{25}$, las novelas de Barnatán pueden ser entendidas e interpretadas sin considerar su estrato kabalístico. Si bien explorando la armazón kabalística del texto se enriquece el entendimiento de los poemas y de las novelas del citado autor, ello no significa que su obra no pueda ser leída por quien no posee conceptos básicos del torrente místico judío.

Por ejemplo, una lectura intertextual de las obras de Marcos Ricardo Barnatán permite apreciar nociones kabalísticas tales como "la percepción de la mujer como recipiente consumidor, resultado del punto de vista falo-céntrico kabalístico" (Tresoldi, La Cábala 33), mientras que, al mismo tiempo, aporta una nueva luz sobre las relaciones femeninas y masculinas.

El vasto conocimiento de Ricardo Barnatán de diversos aspectos de la Kábala se manifiesta en la transformación poética del simbolismo zohárico. Las novelas de Barnatán parecen expresar la demanda de Kafka en Las cartas a su padre: "Pegar la raíz otra vez en los viejos siglos" (27). Consecuentemente, Barnatán crea un nuevo tipo de literatura kabalística ocupada profundamente en los secretos humanos más que en los divinos.

Tanto la poesía como la prosa de Barnatán recuerdan el estilo del Bahir, "libro este que parece contener muchos detalles concernientes al origen de la Kábala donde

\footnotetext{
${ }^{25}$ Najmán de Breslov (1772-1810). Su mensaje se centra en "no perder nunca la esperanza de encontrar la alegría y un motivo de felicidad en todo lo que ocurre. Vivió una época de transformación: el comienzo de la Revolución Industrial, la Revolución Francesa, Byron, Goethe, Mozart. Visionó lo que sería el gran problema del hombre moderno: el vacío interior. Sus reflexiones son válidas para cualquier persona, con independencia del punto interior en el que se encuentre.
} 
se presentan increíbles imágenes femeninas" (Scholem, Conceptos básicos del

judaísmo 22).

Este simbolismo femenino al que se ha hecho referencia anteriormente tiene un papel primordial en el discurso de Marcos Ricardo Barnatán, ya que a través de estas imágenes la voz discursiva femenina manifiesta la melancolía del perpetuo adiós a las cosas que han sido y su intento de retenerlas. No hay en Barnatán un discurso donde no esté presente esta terrible visión de lo que se deshace, y no pretende que esa voz se entienda con la razón sino que se sienta, se viva y se sufra con las raíces de la sangre. Barnatán, entonces, elabora una rica nomenclatura de significación sensual a la que pertenece lo femenino. En la literatura kabalística, así como también en la obra poética de Barnatán, lo femenino, la mujer, la esposa, la hija son símbolos eróticos, no prohibidos, que sirven para sugerir lo amorosamente gozado y el placer último, apetecido del hombre.

Tanto Barnatán como los redactores del Bahir manifiestan que el individuo en estado de éxtasis que lleva al goce más hondo tiene acceso a la existencia más profunda, y es a esta parte a la que ambos pretenden tener acceso.

El parcial entendimiento de las nociones kabalísticas hace que el trabajo literario de Barnatán sea interesante. Así, por ejemplo, el concepto kabalístico de la andrógina ${ }^{26}$ naturaleza de lo divino mencionado anteriormente enriquece la poesía de

\footnotetext{
${ }^{26}$ No sólo entre los kabalistas se comenta sobre la andrógina naturaleza de lo divino, sino que también se afirma que el mal es un principio o una cualidad en Dios mismo, y así G. Scholem lo comenta en $L a$ Cábala y su simbolismo: "Rabí Amora estaba sentado y expuso lo siguiente: ¿Qué significa que Dios ama las puertas de Sión más que las puertas de todas las moradas de Jacob? Las 'puertas de Sión' es lo mismo que las puertas del mundo, pues puerta significa apertura, según se dice en el salmo 118:19: 'Abridme las puertas de la justicia'. De este modo dijo Dios: Me gustan las puertas de Sión cuando están abiertas'. ¿Por qué? Porque pertenecen a las puertas del mal, pero cuando Israel hace algo bueno ante Dios y se porta de tal manera que se hace digna de que aquellas puertas se abran entonces Dios los ama más que a todas las 'moradas de Jacob' en las que siempre reina la paz” (73).
} 
Barnatán, y el erotismo relacionado con el mundo divino se convierte en una sensual expresión poética dentro del reino de las pasiones y emociones.

En su obra literaria, Barnatán también señala más de una vez la dualidad en el seno de la deidad suprema — es decir, en Kéter—, concepto este que ha levantado siempre sospechas entre el rabinato y, por tanto, persecuciones en los más diversos ámbitos. Este concepto es evidente en el poema "El oráculo invocado" del poemario del mismo nombre, cuando la voz poética nos dice:

Si mis sueños no profetizan mentiras, hay en el amanecer brumoso una piel cálida, un cuerpo blanco que se despierta y despierta mientras se derrama un néctar que fue en la noche furor y púrpura densa sed para los labios.

Los amantes saben que morirán, es ley, Pero sus bocas desvanecen la amenaza Para sellar en su unión lo que perdura (1-5, 9-11).

Una imagen bella y sensual como esta es muy fácil de encontrar en los poemas de Barnatán. Después de una noche apasionada, donde el alma se eleva para alimentarse del "néctar" de su amada, esta desciende colmada de deleite. En el lenguaje de Zohar, la deidad asume distintas conformaciones o rostros en sus manifestaciones. Este es un recurso literario o expresivo útil para traducir en forma plástica conceptos abstractos difíciles de abarcar de otro modo, gracias a la naturaleza del símbolo.

Se supone que el lector tiene la discriminación suficiente como para no establecer burdos antropomorfismos metafísicos. Es evidente que Dios carece de forma y no es, por lo tanto, semejante a nada.

Por otra parte, la palabra clave en el Zohar es Conocimiento. A través de sus símbolos y atributos, podemos acercarnos a un cierto conocimiento de Él. En El Árbol de la vida, Madirolas plantea que estos símbolos delineados: 
[componen] un conjunto hasta cierto punto comprensible, pero está claro que Él está por encima de toda delimitación. Dios es infinitamente más que la suma de sus atributos, del mismo modo, cuando decimos que todos los mundos, seres y todos los seres están comprendidos en la forma de Dios. Tampoco debemos entender que entonces Dios es la suma de todos los seres. Como se establece en la máxima Séfer Yetsirá: Él es el sitio del mundo y el mundo no es su sitio. Dios está separado de todas las cosas aunque estas no están separadas de Él: solo existen en Él y por Él (219).

Se llega a la conclusión, entonces, de que al darse forma a Él mismo, Dios ha dado existencia, forma y vida a todo lo que existe. La creación se origina en un acto de Conocimiento. La Creación es algo que sucede en la Mente de Dios ${ }^{27}$. De ahí que el Zohar, al establecer en poderosos símbolos imágenes las ideas anteriores, conciba "la primera conformación de la Deidad como un gran rostro solo sin cuerpo" (Scholem, Grandes tendencias de la mística judía 131), "una inmensa cabeza cuyo cráneo abarcara la circunferencia infinita de todo" (Scholem, Los orígenes de la Cábala 81). Dicho cráneo está lleno del rocío cristalino, el cual destila por su blanca cabellera, y de ahí este versículo, 5:2 del Cantar de los Cantares: “¡Ábreme, hermana mía, amada mía, mi paloma, mi pura, pues mi cabeza está llena de rocío, mis guedejas del sereno de la noche!". Si se contemplan por un instante "dos puntos de sus largos, lisos e inmaculados cabellos, se podrá llegar a la conclusión de que representan la acción o la manifestación de Su pensamiento divino, y las perlas del rocío que por ellos descienden dan lugar a los millones y millones de galaxias que forman el universo manifestado" (Barbero, Lenguas y Cábala 21). "Miremos al cielo nocturno y contemplemos cada estrella como un mundo prendido de Su pensamiento" (Scholem, Hay un misterio en el mundo 71).

\footnotetext{
${ }^{27}$ En La Cábala de Roberto Tresoldi se plantea que "para algunos, entre ellos Isaac el Ciego, el lugar de la voluntad lo ocupa el pensamiento, algo que no ha sido emanado y que pone en funcionamiento el proceso de la Emanación. La Creación, pues, no sería un acto de voluntad, sino de intelecto" (68). Gershom Scholem sostiene que el puro pensamiento retrocede a una posición de dependencia respecto de la voluntad y se convierte en la sabiduría divina, que contempla el plano de la Creación.
} 
La andrógina fundamentalmente es unidad, aunque en ella late de modo implícito la dualidad — asunto que resulta de imposibilidad lógica para En soph, y no tiene ninguna determinación, ya sea que se llame número, ser, afirmación, verbo o luz.

Por este motivo, Issac el Ciego ponía a En soph fuera del Árbol sefirótico, a diferencia de los grupos de Sefarad, que lo colocaron en la parte más elevada de Kéter $^{28}$. Esta discusión aún subsiste entre los kabalistas contemporáneos. ¿Cómo pudiera, entonces, justificarse el estudio de la obra, tanto poética como narrativa, de Marcos Ricardo Barnatán, bajo la lupa de esta compleja interrelación de texto literario y textos kabalísticos?

Los textos místicos - teosóficos incorporan algunas características poéticas, lo que hace de ellos una fuente fértil para la literatura. Tal como afirma Harold Bloom

\footnotetext{
${ }^{28}$ Kéter significa Corona, en idioma hebreo. Y es la primera sefirá del Árbol de la Vida. Kéter se encuentra en una posición superior y además central del árbol. Es el potencial puro de las manifestaciones que acontecen en las otras dimensiones. Representa la esencia, libre y atemporal. Es el principio de todas las emanaciones canalizadas por las otras sefirot. Si la vamos a comparar con la física moderna se puede considerar como el momento cero, es decir, la creación en capacidad, pero no propagada ni esparcida. Una interesante asociación sería compararla con el tiempo de Planck, del BigBang. El concepto de Emanación puede llevar a engaño. En efecto, no se trata del principio de Emanación de los neoplatónicos, aunque el pensamiento de algunos autores pudiera sugerirlo (véase, por ejemplo, la obra de Ibn Gabirol), sino de un proceso dinámico interior del propio Dios. La Emanación, tratada por numerosos autores grecorromanos, así como en muchos textos de la tradición gnóstica o caldea antigua, es un proceso en el cual la energía originaria que emana de la Divinidad rompe la barrera entre la dimensión divina y la dimensión física para transmitirse a nuestro mundo. Los Óraculos caldeos, obra de los primeros siglos de la era común, se refieren muy a menudo a este fenómeno: la energía espiritual se aleja del Padre emanante y se irradia a todo su rededor, y al menguar su luminosidad, se forma la materia, que es energía espiritual congelada. En cambio, para los kabalistas, la Emanación es el despliegue dinámico de acciones internas a las modalidades divinas (sefirot), que solo encuentran un punto de contacto con el hombre en la sefirá más próxima al mundo físico (Malkut). No se trata ya de una emanación procedente directamente del interior de Dios y dirigida hacia su exterior, hacia el mundo creado, sino que está mediada por la estructura de las sefirot, que la preparan para ser transmitida a la estructura secreta y espiritual del Cosmos a través de un filtro importante: la Torá, compuesta por veintidós letras con las que la Divinidad, junto con las sefirot, creó el mundo. El problema del paso de una dimensión a otra se trata de un modo particular en los comentarios a uno de los textos fundamentales de la Kábala, el Séfer ha Bahir, en donde no queda claro si la primera séfira, Kéter, es Dios mismo o bien una entidad separada de Él.
} 
en La Cábala y la crítica, "la Cábala es un cuerpo extraordinario de lenguaje retórico o figurativo" (18).

El uso de múltiples tropos en los libros kabalísticos, como el Zohar, explica por qué pueden ser considerados como fuente de fertilidad para escritores como Marcos Ricardo Barnatán. La perfección del Zohar como libro lo abre a infinitas interpretaciones, pero el libro en sí mismo es una serie de actos interpretativos (Bloom). En este sentido, existe un aspecto importante que correlaciona la meta poética natural del Zohar y el arte poético de Barnatán. La concepción zohárica de la interpretabilidad infinita de cada palabra no aplica simplemente a la Torá, sino a él mismo como tal (al Zohar). En este estudio se afirma que el concepto anteriormente mencionado (interpretabilidad infinita) puede ser aplicado a textos literarios seculares, como es el caso del escritor que ocupa este estudio.

La comparación entre los textos místicos pertenecientes al llamado canon kabalístico y, particularmente, el texto literario de Barnatán obliga al lector a reflexionar sobre la siguiente afirmación hecha por Scholem en Grandes tendencias de la mística judia: "La palabra de Dios lleva infinitas interpretaciones, aunque esta pueda ser definida. Incluso la palabra se ha convertido en una señal en el sentido estricto y es ya una palabra mediada, la cual conserva su valor absoluto" (83).

El toque de lo absoluto se manifiesta mediante la creación de un trabajo literario de arte que no solo expresa de nuevo el significado primordial de la palabra sino que también le permite una interpretación infinita. En este caso es necesario utilizar la teoría de la multi-interpretabilidad como método de investigación. Puede uno darse cuenta de que las teorías posestructuralistas (especialmente las de Barthes y 
Kristeva) se acercan indirectamente al pensamiento kabalista de la interpretación ${ }^{29}$. Solo en algunos casos se hará referencia a las posibles relaciones entre la teoría posmodernista y la parte opuesta: la kabalística.

En Variaciones sobre la escritura, Roland Barthes expone que el propósito de "un autor al escribir una obra, no es el sentido ideal y legítimo a partir del cual se puede interpretar el texto" (56). Él piensa que "en la literatura se pueden encontrar otros indicios de significados" (34). Tales significados, para Barthes, "no vienen dados por el autor, por lo que deben ser creados por el lector a través de un proceso de análisis textual" (24).

Una buena muestra de lo anteriormente comentado se encuentra tanto en Borges, poeta secular, como en Barnatán, poeta y judío observante: usan, entre otras, las mismas fuentes kabalísticas para su obra. Y esto pudiera sugerir una reconsideración de la distinción religiosa - secular de la literatura. Una vez más se puede plantear que la naturaleza ética espiritual de los lectores determina lo que ellos matizan e interpretan, y este hecho hace que ellos sean espíritu y vida, como nos recuerda Barnatán a lo largo de toda su obra. Un estudio profundo puede decirnos que esas fronteras rígidas no son relevantes; es más, no existen. Las operaciones de intertextualidad pueden mostrar los caminos mediante los cuales una doctrina secreta se transforma en un texto literario.

El recurrente tema filosófico de este estudio es la comparación entre la experiencia poética y la mística. Ambos — el texto místico y el literario - ambicionan expresar eso que por definición no puede ser expresado. G. Scholem, en On the Kabbalah and Its Symbolism, describe esa paradoja de la siguiente forma:

\footnotetext{
${ }^{29}$ Para más información sobre la relación entre la Kábala y el posmodernismo, véase La cábala y la crítica de Harold Bloom.
} 
The mystic discovers in language [...] something pertaining to its structure which is not adjusted to a communication of what is communicable but rather - and all symbolism is founded on this paradox - to a communication of what is non communicable, of that which exists within it for which there is no expression, and even if it could be expressed, it would in no way have any meaning, or any communicable sense (93).

Tanto si consideramos el texto místico como teosofía (conocimiento profundo de la Divinidad mediante la meditación personal y la iluminación interior) o como expresión de una experiencia mística, este se encuentra confinado dentro de las fronteras del lenguaje. La aspiración del místico es expresar la esencia de lo inexplicable (como puede ser el reino de lo divino) dentro de los límites permitidos. La necesidad que este tiene de comunicar la unificación con Dios - la Unio Mystica - es especialmente incomunicable.

En los textos literarios, la paradoja existe de forma muy similar. Puede ser que la aspiración del poeta de tocar la esencia interna de las cosas y comunicarla a través de un lenguaje poético nunca se lleve a cabo en su totalidad. La unificación del poeta con el reino de las emociones — análoga a la Unio poetica — no puede ser auténticamente reconstruida. Barnatán asegura que el lenguaje, con todas sus asociaciones, no nos introduce para nada en el área interna, en la esencia de las cosas. La lengua, en sí misma, es como una barrera entre el área interna y la esencia de las cosas. "Este vacío abismal existente entre el área interna y su expresión poética es una característica central de ambos: de los textos literarios y los kabalísticos” (Bloom, La Cábala y la crítica 55). Parece que la urgencia por expresar en palabras es más fuerte que la parpadeante conciencia de la paradoja interna. En "Una rosa amarilla", de su libro El hacedor, Jorge Luis Borges menciona este concepto de la siguiente forma: 
Entonces ocurrió la revelación. Marino vio la rosa, como Adán pudo verla en el Paraíso, y sintió que ella estaba en su eternidad y no en sus palabras y que podemos mencionar o aludir pero no expresar y que los altos y soberbios volúmenes que formaban en un ángulo de la sala una penumbra de oro no eran (como su vanidad soñó) un espejo del mundo, sino una cosa más agregada al mundo (38).

No en vano, en hebreo, "la palabra arte se dice omanut, y este término está intrínsecamente y radicalmente relacionado con el vocablo neuma, que significa fe" (Satz, Senderos en el jardín del corazón: poética de la Kábala 61). En última instancia reflejan una sola y única realidad: la realidad profunda del hombre en éxtasis cuando se integra a la totalidad divina. Algo tiene que ver esto con el universo platónico, en el cual el bien, la verdad y la belleza se confunden.

El arte de Marcos Ricardo Barnatán viene del ser, y esa es la razón por la cual su obra se hace penetrable, profunda, y evoca aquello que es imposible expresar en una concepción prosaica. El círculo de Barnatán se completa al añadir a su obra el ingrediente del Amor. De esta forma, Barnatán puede cantar el canto de su alma y encontrar en ella el todo, la plenitud de su espíritu; puede cantar el canto al pueblo, saliendo así del círculo de su alma individual. En "Sobre doce rocas”, la voz poética le canta al pueblo; entonces, la voz poética se va alejando poco a poco, se distancia y se extiende para entonar un canto al hombre en general:

La Roca, su obra, es perfecta.

Es verdad, y perfecta es la ortiga

Que crece secular entre las rocas.

Perfecta es la ciudad que se levanta

Sobre las doce rocas engastadas.

Laúd para celebrar la fuerza de su nombre, Y para invocar al que la hizo así. ¿Guardas acaso el cadáver de la flor, herido azahar de perfumada muerte?

Este poema eleva al lector por encima de las fronteras, hasta alzarse con toda la existencia, con todos los seres, con todos los mundos, para así poder expresar su 
canto. Une de esta forma todas las posibilidades: el canto del alma, el canto del hombre, el canto del pueblo y el canto del Universo. La ciudad en este poema aparece como imagen de la Creación, la cual, como dice la voz poética, es perfecta. La última pregunta está dirigida el lector. La voz poética, después de anegar el poema con halagos a la Creación, le dirige una pregunta que pudiera considerarse una llamada, un grito al lector. La voz poética quiere recordar y mantener viva la pertinencia metasimbólica de los términos religiosos.

El poema se refiere al pensamiento religioso que está en perpetuo peligro de dar primacía a los conceptos y a los dogmas y perder la inmediatez de las intuiciones, “de olvidar que lo conocido no es sino un recordatorio de Dios, que el dogma es una prenda de Su voluntad, y la expresión, lo inexpresable en su nivel mínimo" (Sosnowski, Borges y la Cábala: la búsqueda del verbo 71). Por tanto los conceptos, las palabras, las obras literarias heredadas y ancestrales, no han de ser vistos como celosías — advierte la voz poética — sino como ventanas.

1.4.1. Entre lo revelado y lo propio del hombre surge una ampliación de la literatura sagrada

Es curioso el interés de los místicos judíos en la siguiente pregunta: ¿Por qué el mundo fue creado con la letra bet si no es la primera letra del abecedario? Con esta pregunta comienza el libro del folclor y leyenda judío Séfer ha Aggadá ${ }^{30}$, editado por Bialik $^{31}$. La respuesta parece muy sencilla: la letra bet hebrea está cerrada en tres lados y abre al frente. No está permitido investigar lo que está arriba (los Cielos), lo

\footnotetext{
${ }^{30}$ Véase: Resumen para una discusión de Dr. Avraham Elkayam, del departamento de Filosofía en Bar Ilan University.

${ }^{31}$ Hayim Nahman Bialik y Yehoshua Hana Ravnitzky editaron el Libro de leyendas del Talmud y el Midrash, que contiene leyenda e historias. Algunas de ellas son fantásticas, otras más simples, pero todas ellas abren nuevas puertas y terminaron por airear y actualizar las leyes, tradiciones interpretaciones y exégesis sobre las historias bíblicas.
} 
que está abajo (las profundidades) ni lo que fue antes (de los seis días de la Creación). Solo está permitido hacerlo desde el tiempo en que el mundo fue creado hacia adelante.

Barnatán, haciendo uso de este concepto místico, aboga no por un secreto que, a beneficio de la trama, el lector se demore en revelar. Para Barnatán, el secreto es un espacio en blanco que hace posible cada poema y cada novela. Es aquello que nunca será dicho. Barnatán sabe que el lector puede sentirse arruinado, dolido, abandonado; sin embargo, lo evita, y además lo compensa con una rica experiencia estética. El autor no solo investiga la dimensión permitida, la escala completa del ser humano, sino que con valentía corre las cortinas y mira más allá, donde ya Alguien, ávidamente, espera.

Tanto su prosa como su poesía intentan capturar una experiencia histórica, emocional y espiritual y, al mismo tiempo, tomar conciencia de la naturaleza del lenguaje y de sus dimensiones. Su término es "revelar lo que se ha ocultado y entonces ocultar lo revelado, y es el proceso de la creación lo que permite ese viaje dual" (Pinjas Comentarios 73). Barnatán, muy consciente de ello, advierte que, a través del significado poético, el creador oculta sus revelaciones personales. El texto literario codifica la experiencia y el lector está expuesto a descifrarlo. En otras palabras, las letras y las palabras son simultáneamente las herramientas para alcanzar el meollo de los conceptos, y también de crear barreras entre ellos. Esta percepción es declamada por Barnatán en su poema "Arte poética":

La letra más que marcar llamea Desgarra la esteparia faz del papel Para ser cuerpo en el tiempo Madura gacela palpitante

Un silencio transparente hiere Es el blanco vacío derramado 
El rayo que en vano nombra.

Ahora el fuego ha encendido luces

Para dar significado al eclipse

Y desvelar el misterio escrito.

La torpe obscuridad se fatiga

Siete veces el esplendor dará batalla

Y la vida y la muerte serán del poeta.

La voz que brota de la obra artística de Barnatán se apega a la palabra viva y

pretende pasar de la palabra "incomunicante", que tanto une los abismos del hombre, a la palabra comunicante, a la palabra paradigmática, a la palabra, en última instancia, universal. Para Barnatán, "ser poeta no es ser portador de una oración, de una palabra, de una idea, de un mensaje" (Olivio, Nueva poesía española 55). Para él, ser poeta es, ante todo, ser. El artista no es un filósofo, ni un pensador profesional, ni se dedica a las elucubraciones y especulaciones. "El poeta es un ser que vive su verdad y lucha por ella y combate y experimenta la agonía del espíritu que tiene que impregnar a la realidad con su aroma" (Posada, 40 años de poesía española 22). No existe paz para el espíritu poético, nos viene a comentar la voz poética. Siempre está disconforme y descontento. Nada en esta realidad jugada a medias tintas puede satisfacerlo. Ser poeta, ser escritor, es ser rebelde, y esa rebeldía, en ciertos espacios, es implacable.

La obra de Barnatán pretende esclarecer esa llegada de la evidencia disfrazada y encubierta. "El artista puede ser que despierte, sugiera e insinúe ese significado oculto, e incluso puede ser que se sublime y llegue más allá, donde entregue su existencia, su vida a esa misión" (Oviedo Historia de la literatura hispanoamericana: posmodernismo, vanguardia, regionalismo 101). Ese número siete al que se hace referencia en el poema simboliza el estado de totalidad y de perfección: la llegada del Entendimiento. 
El número siete es el número que marca la superación de un periodo especial donde se crea. Esta es la razón por la cual el Shabat —el séptimo día — es el día especial y el más importante en la vida judía, pues entonces la Creación se prolongó hasta llegar a ese momento de descanso. Por otra parte, entre $\operatorname{Pesaj}^{32}$ y $\operatorname{Shavuot}^{33}$ se pueden contar siete semanas, y es cuando se entrega la Torá. Precisamente las dos festividades —Pesaj y Shavuot — tienen una duración de siete días. Dentro del judaísmo existen siete festividades en las que está prohibido trabajar (Pesaj, Sucot, Shmín Atzeret, Simjat Torá, Rosh Hashaná, Iom Kipur y Shavout). Otra nueva relación con el número siete es que desde los patriarcas hasta Moisés hay siete generaciones; lo mismo sucede con el hecho de que Dios se le revela a Abraham siete veces en toda su vida, y por otro lado Isaac, recibe siete bendiciones de Dios. Y para terminar, sin mencionar todos los informes relacionados con el número siete, existen siete preceptos de Noé ${ }^{34}$ que no son únicos para el pueblo hebreo, sino para todas las naciones de la Tierra.

\footnotetext{
${ }^{32}$ Pésaj es la festividad judía que conmemora la salida del pueblo hebreo de Egipto, relatada en el libro bíblico del Éxodo. El pueblo hebreo advierte en el relato de la salida de Egipto como el móvil que marca el nacimiento del pueblo como tal .La festividad dura siete días ( son ocho fuera de Israel), y durante la misma está prohibida la ingestión de alimentos derivados de cereales fermentados. En su lugar, durante la festividad se acostumbra a comer pan ácimo. Según la tradición, el pueblo judío salió de Egipto con mucha prisa y sin tiempo de prepararse, por lo que no hubo tiempo para dejar leudar el pan para el camino. Durante la primera noche de la festividad (las dos primeras en la Diáspora) se acostumbra a llevar a cabo una tradicional cena, durante la cual se relata la historia de la salida de Egipto.

33 Shavout es la festividad que conmemora la entrega de la Torá por parte de Dios a Moisés, en el Monte Sinaí. Los judíos acostumbran pasar toda la primera noche despiertos en la sinagoga estudiando Torá.

${ }^{34}$ Los siete preceptos universales fueron asumidos por los descendientes de Noé bastantes siglos antes de la entrega de la Torá.1. No adorar a ídolos o falsas deidades (Bereshit / Génesis 9:6); a Adán se lo dice en (Bereshit / Génesis 2:17). 2. No blasfemar (Bereshit / Génesis 9:1); A Adán se lo dice en (Bereshit / Génesis 1:28). 3. No asesinar (Bereshit/Génesis 9:5). 4. No robar (Bereshit / Génesis 9:3); también se lo dice a Adán en (Bereshit / Génesis 2:17). 5. No mantener relaciones sexuales ilícitas (Bereshit / Génesis 9:9); se lo dice a Adán en (Bereshit / Génesis 2:24). 6. No comer carne de animal con vida (Bereshit / Génesis 9:4). 7. Establecer cortes de justicia (Bereshit / Génesis 9:9); también se asume de (Bereshit / Génesis 19:9) lo que garantiza que los pactos sean debidamente acordados y mantenidos son la justicia y el juicio.
} 
El número siete indica finitud y comienzo al mismo tiempo, exige reposo para más tarde iniciar una secuencia de etapas. "Cuando el dictamen o la solución previa, si es que la había, ya no sacia, entonces se parte del sosiego y de la placidez para emprender la complicada tarea de rastrear la respuesta" (Waldman, Más allá de la duda 115), la cual intenta regular el caos y así hacer al mundo más accesible.

La obra de Barnatán está llena de alusiones y connotaciones aisladas de la tradicional bibliografía hebrea, bien sea de la Torá, de la literatura talmúdica o del Midrash, por lo que su obra se hace reservada y hermética debido, entre otros factores, a la enorme extratextualidad que hay en ella. Según Barnatán, más adelante, durante el curso de la renovada productividad humana, se ampliará incluso el ámbito de la literatura sagrada. En ella se incorporarán nuevas comunicaciones a las antiguas, generándose así una especie de "tierra de nadie entre lo que pertenece propiamente a la revelación y lo que es propio del hombre de su tiempo" (Veghazi, Los comienzos de la ciencia moderna judía 36).

Así ha sucedido, por ejemplo, en el judaísmo, cuando junto con la Torá — inicialmente el único escrito que reivindicaba un carácter revelado — se recopilaron otros escritos que fueron incorporados al ámbito de la tradición. Sin embargo, Barnatán cree que nada de lo creado por el ser humano es fruto de la productividad de este, sino que proviene de un arcano impulso, y le es aplicable aquello que Végh citó en una ocasión de Max Scheler: "The artist is merely the mother of the work of art; God is the father ${ }^{35 \%}$. Esta es la razón por la cual el poeta novísimo se acerca al concepto de la Shejiná en su obra literaria, ya que en él encuentra la disposición

\footnotetext{
${ }^{35}$ Citado en Scholem, Tradition and Commentary as religious Categories in Judaism: Studies in Comparative Religion, Vol.3 N. ${ }^{\circ} 3$ (summer, 1969).
} 
exacta de la relación humana con sus raíces más profundas. En él encuentra ese contacto vivo en el que el hombre capta la verdad primordial y se vincula a ella a través de las generaciones en el doble lenguaje de dar y recibir.

1.4.2. Marcos Ricardo Barnatán: un admirador de los maestros de la alegoría

Es una forma tradicional del discurso del Midrash ${ }^{36}$ llevar al lector hacia una explicación alegórica que supuestamente pretende ofrecer una exacta interpretación del tema que está siendo discutido. La explicación suele ser más compleja que el texto original, y siempre se convierte en un marco de referencia diferente.

Barnatán hace uso de su conocimiento kabalístico e intenta dar una explicación alegórica al devenir diario. No mantiene el mismo nivel, sino que se debate en un movimiento sin fin. Por ejemplo, el poema "El oráculo invocado" puede ser leído como la mirada llena de turbación y sospecha hacia el futuro de su vida personal, pero al mismo tiempo puede ser interpretado metafóricamente como la búsqueda ansiosa de una meta arcana donde se oculta, secreta, la identidad profunda, la revelación esperada, y en un nivel existencial, la continuación de la vida del pueblo.

Curiosamente su método es típico en los textos kabalísticos y adopta la forma del distintivo discurso del Midrash. La lectura es posible a distintos niveles, y cada uno nos va llevando a una hondonada cada vez más profunda y asombrosa del conocimiento.

\footnotetext{
${ }^{36}$ Midrash significa "explicación” y su plural es midrashim. Es un vocablo hebreo que designa un método de aclaración, comentario o investigación de un texto bíblico, encaminado al estudio que facilite la comprensión de la Torá. El término midrash también puede referirse a una compilación de enseñanzas midráshicas en forma de comentarios legales, exegéticos u homiléticos del Tanaj (Biblia hebrea).Variantes del midrash: la halajá, interpretación normativa; la agadá, interpretación alegórica o narrativa, y el pésher, interpretación visionaria.
} 
Cuando se encuentra una explicación simbólica en los textos kabalísticos, se puede estar seguro de que las cosas no son como parecen. Un rey no es un rey y una princesa no es una princesa, sino que son símbolos de los diferentes aspectos divinos.

El inepto no puede divisar más allá de lo que se encuentra establecido. Solo los místicos o los poetas buscan aquello que está detrás de las cortinas, una vez que el exegético ejemplo resuene a varios niveles. En la nota a la segunda edición de $L a$ antología del Zohar, Marcos Ricardo Barnatán explica que "las verdades no se le obsequian al lector de una forma simple, sino que llegan sugeridas a través de símbolos y de mitos a la forma del lenguaje bíblico del libro de Job” (12). El lector sugiere Barnatán — "ha de acercarse al libro guiado por una fuerte voluntad de búsqueda, y en él hallará un seguro estímulo para encontrar una interpretación acorde al pensamiento contemporáneo" (9). A pesar de indicarnos un camino a seguir, siempre se advierte un gran peligro cuando emprendemos un largo viaje, como es el de la alegoría.

Este peligro se eliminaría si se lograra esclarecer la diferencia entre el discurso de los maestros de la prosa y el de aquellos de la alegoría. Los primeros pueden llevarnos, a través de sus interpretaciones, a falsas creencias. En cambio los maestros de la alegoría, al no interpretar, no cometen ese error: se limitan a trasladar la representación abstracta cognoscible a conceptos cotidianos. Es interesante leer la definición de alegoría que Pedro Calderón de la Barca nos ofrece en El verdadero dios Pan:

La alegoría no es más que un espejo que traslada lo que es con lo que no es, y está toda su elegancia en que salga parecida tanto la copia en la tabla, que el que está mirando a una 
piense que está viendo a entrambas (17).

Queda claro que la tarea de una lectura profunda va más allá del concepto de una sola interpretación alegórica, como postuló Dante. Kabalísticamente hablando, se puede asegurar que "cada versículo de la Torá contiene infinitas interpretaciones" (Scholem, Los orígenes de la Cábala 67), y este es uno de los pilares místicos del judaísmo que más llama la atención de Barnatán. Es el móvil por el cual este autor plantea que el elemento determinante de la literatura no es tanto la escritura como la lectura.

"Para una persona cuyo destino es componer palabras, para un poeta o un escritor que crean mundos con palabras, tal vez sea este un pronunciamiento extremo" (Anderson, Los orígenes de la postmodernidad 89). El asumir que el lenguaje es la barrera entre el individuo y el núcleo o la identidad de las cosas es aparentemente opuesto a la motivación poética de Barnatán. Este escritor sabe que "el alma pocas veces sabe elevar sus más hondos secretos a los niveles discursivos de la mente" (Idel, La Kábala y su interpretación 132). De ahí que él no equipare el acto de discernimiento con el de la expresión. En la obra de Barnatán hay una posibilidad, ya que la limitación aparente del lenguaje se convierte en asunto provechoso y de interés. Según la obra del escritor que nos ocupa, solo quienes hayan vivido días en los que de nada servían las palabras, "solo los que hayan experimentado el des-conocimiento último, el silencio de un alma golpeada por el asombro, la total mudez, solo ellos son capaces de penetrar en aquel significado más grande que la mente" (Heschel, Dios en busca del hombre 67). Podemos encontrar un concepto análogo a este — característico en la obra de Barnatán — en el Zohar cuando se plantea que en la Torá se revela un pensamiento que: 
[...] por un instante y de inmediato se viste con otra prenda, de modo que allí permanece oculto y no se muestra. Los sabios, cuya sabiduría les agudiza la mirada, penetran a través de la prenda hasta la esencia misma de la palabra que aquella oculta. Así, cuando fugazmente la palabra se revela, en ese primer instante, aquellos cuyos ojos son sabios pueden verla, aunque pronto vuelva a ocultarse" (Zohar, Vol. II, $\left.98 b^{37}\right)$.

Esta es la razón por la cual existe tanta obsesión por una correcta interpretación de lo que se lee en los textos sagrados. Entre los eruditos, se llama hermenéutica (del griego, hermeneutike) al conjunto de normas que se utilizan para interpretar cualquier texto. La hermenéutica sacra o bíblica es la que se dedica a la interpretación de las Sagradas Escrituras, por lo que es tanto un arte como una ciencia. Cuando se aplica la hermenéutica a un texto, lo que se hace es una exégesis. Este vocablo proviene de un término griego que significa guiar, exponer, explicar. En la tradición judía este cúmulo de interpretaciones se fue formando en un proceso de siglos y finalmente se registró como la literatura talmúdica, que no es más que una compilación de análisis exegéticos y hermenéuticos de los libros sagrados (la Torá).

El principio de esta tradición se remonta a Esdras, a quien se considera el fundador de lo que luego sería la institución del escriba: aquellos hombres que se dedicaban a estudiar y explicar los Libros Sagrados. En términos generales, los métodos de interpretación judíos se dividían en cuatro tipos: "el peshat, que buscaba la traducción literal; el remez, que indagaba por los significados implicados en el texto; el derash, más orientado a una explicación homilética, y el sod, que se interesaba por lo místico y lo alegórico en el texto" (Knight, Simbolismo cabalístico 89). Las interpretaciones del texto hechas en esa forma aparecen en el Talmud como los midrashim que son exposiciones exegéticas que tenían el objeto de investigar las posibles explicaciones y aplicaciones de la ley.

\footnotetext{
${ }^{37}$ Véase también Platón, Epistolas, VII, 341.
} 
Había diferencias entre los principios de interpretación que aplicaban los judíos que vivían en Israel y los de la dispersión o diáspora, especialmente aquellos de Alejandría. Los primeros se inclinaban por la interpretación literal, mientras que los segundos ponían énfasis en la interpretación alegórica, bajo la influencia de la filosofía de Platón. Según esta, no debe creerse nada que parezca indigno de la $\operatorname{Deidad}^{38}$

Se puede decir que la interpretación de los textos sagrados por el pueblo ${ }^{39}$ del libro, vital. El pensamiento místico judío da razón de muchos de los misterios del pueblo hebreo, y en particular ofrece sentido a su existencia. Israel no solo tiene la misión de propagar la ley transmitida por Moisés, sino también $-\mathrm{y}$ sobre todo — la de hacerla más concreta en la vida de cada día, llevando a cabo una obra de santificación del mundo, con la conquista de la Redención reparadora.

El estudio de la Torá y el discernimiento de los mecanismos que regulan su vida interna (el texto, los vocablos y cada una de las letras) permiten captar cada vez mejor la voluntad del Creador y los secretos del Universo, de los que la Torá constituye el código genético. La tradición medieval ha transmitido los cuatro niveles de lectura de cada texto en los breves versos aprendidos de memoria por generaciones de estudiantes, como podemos encontrar en Comentarios sobre el Jumash: "La letra cuenta las vicisitudes; lo que debes creer, la alegoría; lo que debes hacer, la moral, y aquello a lo que debes tender, la anagogía, el recorrido espiritual ascendente" (76).

\footnotetext{
${ }^{38}$ Véase Conceptos básicos del judaísmo: Dios, Creación, Revelación, Tradición, Salvación, de Gershom Scholem: "La fuerza creadora concentrada en el nombre de Dios, la única palabra realmente emitida por Dios, supera con mucho lo que cualquier palabra creada, cualquier expresión humana puede abarcar. Nunca se contendrá por completo en la palabra humana y finita” (88).

${ }^{39}$ Son el pueblo del libro, porque según los judíos cuentan en su tradición con el libro de los libros: la Torá.
} 
Una de las tendencias que se encuentran en la obra de Barnatán es la intención de experimentar una expansión, a la fragmentación de un mundo que se disgrega. Marcos Ricardo Barnatán demuestra que la alegoría puede representar la duda y la enajenación del hombre moderno.

Barnatán presenta en su obra el reverso de lo que se veía en la alegoría tradicional. En lugar de presentar un hermoso cuadro simbólico de una utopía —es decir, un mundo ideal inexistente—- Barnatán ofrece a través de imágenes las limitaciones y fracasos del hombre, pero al mismo tiempo su potencial. Sus personajes simbolizan dilemas existenciales que el hombre moderno debe confrontar.

Estructuralmente, las alegorías de Barnatán son oblicuas, ya que contienen una dualidad de significado sin explicar nada en específico. Barnatán nunca dice lo que en verdad desea expresar, pues ello daría al lector la oportunidad de sentirse demasiado cómodo y seguro de sí mismo.

La ambigüedad en la obra de Barnatán es intencional, y en ella reside una parte sustancial de su mensaje. Esta ambigüedad refleja las oblicuidades morales y espirituales de nuestra época.

En la obra de Barnatán, tanto la voz poética como la de sus personajes principales vagan inmersas en una búsqueda. Sin embargo, su búsqueda no parece dirigirse a ningún destino específico, y por todo el texto algunas veces se percibe una actitud que sugiere aburrimiento y desinterés. Aparentemente sus textos no proveen direcciones que conduzcan a ningún destino en particular.

Aunque la búsqueda no tiene dirección ni propósito, el texto lleva al lector hacía una actividad perpetua: las ansias por vivenciar la libertad. El texto de Barnatán proporciona pocos detalles y evita cualquier descripción sensacional de las cualidades de los textos religiosos: simplemente crea un aura de misterio. Su lenguaje neutro 
confronta al lector con un mundo extraño que tiene una combinación perturbadora de lo elusivo y lo familiar. En palabras de Gay Clifford $^{40}$, esta estupefacción de describe así:

La extrañeza del pasaje deriva no tanto de su exotismo, sino del hecho que es tan neutro, tan indefinido, y sin embargo sugiere inmediatamente que quiere decir algo importante [...] una parte de esta urgencia viene de la neutralidad del vocabulario [...] aceptamos que estas cosas son familiares de alguna manera, aun mientras sentimos que son remotas [...] sentimos la necesidad de seguir leyendo para comprender esa enigmática falta de congruencia. Los mundos de la alegoría son solamente medios familiares y son raras veces seguros (24).

La obra de Barnatán revela los aspectos negativos del hombre moderno: incertidumbre existencial, enajenación y deshumanización, pero no refleja desesperación, pues deja un espacio de libertad reservado para el hombre.

Según el escritor, la iniciativa pertenece al hombre: la gran intuición iluminadora no es dada al hombre, a menos que esté preparado para recibirla. Para Barnatán, Dios concluye, mas el hombre comienza. Cuando el hombre está dispuesto a decir "yo soy de mi amado" entonces "su deseo es hacia mí" (Zohar, vol. 1, p. 77b). Barnatán asegura, a través de su obra, que Dios no se halla cómodo en el mundo de insensibilidad, de lóbregos callejones y de hostilidad. La Torá no tiene gloria si el hombre se mantiene apartado. El objetivo es que el hombre sea una encarnación de la Torá, que la Torá more en el hombre, en su alma y en sus actos. La meta es la transformación del hombre a través del proceso liberador que nos ofrece ese encuentro, esa presencia, experimentado en actos. En el poema "Wound", la voz poética transmite una inmensa angustia. En este espacio lleno de espejos, soledad, niebla, donde solo habita el silencio, el individuo está llamado a participar de lo

\footnotetext{
${ }^{40}$ Para más información, véase Las transformaciones de la alegoría, de Gay Clifford, publicada en 1974.
} 
divino a través de la creación de un puente entre él y Dios. Y lo que manifiesta

Barnatán en "Wound" es que ese desasosiego, que puede recabar en la inmisericorde

resignación, solo puede ser rescatado a través de nuevas búsquedas y nuevas

exploraciones del lenguaje, herramienta que solo se encuentra en el escenario del

hombre y a través de la cual es posible transparentar nuevos y diferentes sentidos.

El discurso es, en un nivel inicial, una forma de comunicación entre los

hombres, y en su conformación simbólica se halla ese componente que se encuentra

entre el discernimiento del hombre y el resto del Universo ${ }^{41}$. La importancia del verbo

ha sido sacralizada; el libro ha sido encumbrado a la categoría de Verdad Absoluta.

En el poema "Wound” la voz poética, de una forma escabrosa, así lo deja establecido.

Pregunta en los inquietos espejos

En la soledad mortal de los cristales

la niebla neblina mancha de humo

grabará sin quererlo sin sentirlo.

Flor cincelada o selva de pétalos

El Nombre

Entre las sombras que inflamadas surgen

cofas de navíos sumergidos

gritos inútiles

sonrisa crispada o nube.

Él creció en el silencio

de las estatuas mutiladas

y en el lívido verano de los muertos

se hizo príncipe de luz

ópalo encendido por amorosas brasas.

Los galgos blancos y helados

correrán hacia ti

como venenosas panteras

azuzadas por el olvido.

Qué húmedos cuerpos pueden detenerte

Si tu destino fue grabado y tiembla (1-21).

\footnotetext{
${ }^{41}$ Véase Scholem, Conceptos básicos del judaísmo: Dios, Creación, Revelación, Tradición, Salvación, donde cita a Efraín de Sedylkov [autor destacado de literatura jasídica]: "Hasta que los sabios no la investigan, no está de la Torá más que una mitad, hasta que por sus investigaciones se convierte la Torá en un libro completo. Pues en cada generación la Torá es investigada [interpretada] según las necesidades de esa generación, y Dios ilumina los ojos de los sabios de la correspondiente generación [para que ellos] en su Torá perciban lo conveniente [para ellos] (84).
} 
La voz poética sugiere la certeza de que el hombre conquistará la libertad. Como "galgos blancos y helados/correrán hacia ti" (15-16), dice la voz refiriéndose a que únicamente a través de la fe el ser humano saldrá de esa "soledad" (2), de esa "niebla" (3), de esa "sombra" (6) a la que se refiere en la primera parte. Incluso es capaz de referirse a ese futuro encuentro como algo que ya está predestinado: "qué húmedos cuerpos pueden detenerte /si tu destino fue grabado y tiembla” (19-20).

La gran premisa a la que se refiere el poema es que el hombre es capaz de superarse al él mismo, y es justamente esa facultad la que constituye la esencia de la libertad.

Él creció en el silencio de las estatuas mutiladas y en el lívido verano de los muertos se hizo príncipe de luz ópalo encendido por amorosas brasas (10-14).

Según Hegel, "la historia del mundo no es más que el progreso de la conciencia de la libertad” (138). Aquí cabe preguntarse ¿cómo es que se puede estar seguro de que la libertad no es un concepto artificioso o engañoso? Por el término libertad se entiende la independencia de la voluntad respecto a condiciones previas.

La obra de Barnatán lleva al lector a hacerse muchas preguntas: ¿Puede ser que la voluntad sea independiente del carácter de la persona o las circunstancias que lo rodean? ¿No es toda acción resultado de un factor previo? ¿Todo momento presente no lleva una carga del pasado? ¿Se puede afirmar que dominamos las determinaciones de nuestra voluntad? ¿A quién se pudiera considerar libre? Todas ellas están en la agenda de Marcos Ricardo Barnatán y serán consideradas al concluir este estudio.

En la obra de Barnatán, la supervivencia del hombre depende de la convicción de que hay algo que merece el precio de la vida. Depende de la receptividad para 
percibir la supremacía de lo perdurable. Esa convicción puede estar adormecida, pero despierta ante el desafío de un estímulo. Ahora bien, si Barnatán logra con su obra estimular este sentido en el lector, se tendrá que esperar a estudiar su obra, para más adelante llegar a una conclusión. 
Si alguno se alza más allá de la sustancia y del pensamiento, no llegará a una sustancia y un pensamiento, sino que más allá de la sustancia y el pensamiento atisbará un Algo maravilloso que no tiene en sí ni sustancia ni pensamiento.

Enéadas VI, 7, 40. Plotino

\section{ENCUENTRO ENTRE POESÍA Y KÁBALA ALGUNOS CONCEPTOS EN COMÚN}

La hipótesis principal de este capítulo es que la Kábala comparte con la poesía una perspectiva específica de la escritura, de la creación y del lenguaje en un sentido extenso. Conforme a algunas afirmaciones hechas por Gerschom Scholem, los poetas tienen un vínculo con los expertos de la Kábala aun si se resisten a la formulación teológica.

Según Gil Anidjar, leer la Kábala como literatura sería posible si las divisiones entre exégesis y literatura, entre pensamiento y filosofía, entre religión y literatura no fuesen tan rígidas. Por otra parte, Harold Bloom formula que la influencia se concibe comúnmente como un movimiento de arriba abajo, desde una fuente poderosa y atrayente hacia un recipiente vacío o fácilmente modificable. Sin embargo, su estudio da cuenta de una complejidad extrema, pues el intérprete se encuentra ante un conjunto de factores vastos y de muy difícil aislamiento. Entre los textos del pasado y los lectores del presente se produce un encuentro que resulta enriquecedor para ambas partes.

De esta forma se llegará a la conclusión de que, en ese encuentro entre poesía y Kábala, se transforma a las dos partes involucradas sin que por esta razón se borre la línea fronteriza que existe entre el arte poético y la experiencia mística.

Se llegará a la conclusión de que leer la Kábala como literatura es mostrarse de acuerdo con la agudeza de un lenguaje cuya pujanza imaginativa y retórica se 
ocupa de los textos; es rememorar una fuerza y una autoridad expresiva, algunas

veces ética, que debe ser vista con sumo cuidado. Sin embargo, la fe es el reverso del acto artístico, ya que esta última intenta apresar lo intangible en lo tangible. En la fe no se intenta descifrar ni articular en los términos propios del hombre, sino que se eleva este por sobre su propio discernimiento.

\subsection{LA CONTRACCIÓN DEL ESPÍRITU (TSIMTSUM)}

En su artículo "El arte vacío"42, Marcos Ricardo Barnatán explica la necesidad de un espacio fértil para el artista donde pueda desarrollar una poética extensible a cualquier actividad artística y que esta sea purificada, además de comprometida.

Hace unos años se confió a uno de los críticos internacionales más mediáticos la organización de la Bienal de São Paulo, y él decidió dar el gran salto y anunciar que esta se abriría sin la presencia de ningún tipo de obras. Así lo informó el Semanario

Cultural de Caracas el 17 de diciembre de 2008 en su número 23:

Un gran espacio vacío, algo poco habitual en grandes ciudades como São Paulo, ha sido la apuesta de la Bienal de Arte para este año que, con este nuevo formato, "pretende romper con los modelos establecidos", afirmó hoy el comisario de la muestra, Ivo Mesquita.

"Hoy en día se celebran más de 150 bienales en el mundo y todas ofrecen las mismas cosas", afirmó Mesquita, quien aseguró que el objetivo de su equipo fue "inmiscuirse en la suspensión del proceso" de producción de estas muestras y el nacimiento de una nueva perspectiva.

"Vivimos inmersos en una cultura en la que todo el tiempo estamos consumiendo, tenemos que estar viendo, oyendo o comprando alguna cosa, por lo que este gran vacío sirve para dejar al individuo con sus ideas y sus expectativas sobre lo que es o no es el arte".

"El espacio vacío es una metáfora sobre cualquier cosa, cada uno lo interpreta", explicó Mesquita, quien puntualizó que él, como comisario, no pretendió hacer ninguna crítica a la "pobreza de la producción artística actual”, sino simplemente innovar sobre el concepto de arte.

\footnotetext{
${ }^{42}$ El arte vacio es un artículo de Marcos Ricardo Barnatán que apareció en Blogoteca el 29 de noviembre de 2007.
} 
Según afirma Barnatán en "El arte vacío”, "en ese supuesto vacío fértil se nos invita a meditar, a reflexionar sobre la cualidad invisible del arte. ¿Para qué queremos mostrar obras inservibles?”. Pero además agrega que “es mucho mejor ofrecer el vacío creador para que cada cual se emocione con lo que quiera o, lo que es mejor, con esa nada hecha cuerpo en el aire, en el espacio libérrimo, despojado de cualquier manipulación”.

Y es así como comentaban los críticos de arte dos años más tarde sobre el evento experimental conocido por el nombre de "Homenaje al vacío" en el Semanario cultural de Caracas el 30 de septiembre del 2010 en su número 117.

La bienal de Sao Paulo sale del "vacío" y regresa con la fuerza del arte y la política.

La 29. ${ }^{\text {a }}$ Bienal de Sao Paulo abrió sus puertas al público el pasado 25 de septiembre, salió del "vacío" artístico de la edición anterior y regresa con la fuerza y polémica que despierta la manifestación conjunta del arte y la política.

Concebir es gestar un estado de disponibilidad donde la primera cosa instaurada es el vacío, un espacio vacío, una dimensión vacía, pues lo único que el artista crea, acaso, es el espacio de la creación. Y en el espacio de la creación no hay nada. La creación de la nada es el preámbulo irrefutable de toda creación.

Marcos Ricardo Barnatán juega de forma obvia con ambas posibilidades: en el espacio de la creación hay ausencia, pero el artista, para poder llevar a cabo su faena, legitima la nada. Suerte de trabalenguas que remite a Isaac Luria y a los kabalistas de la Escuela de Safed (siglo XVI).

Isaac Luria (1534-1572) nació en Jerusalén y, aunque de origen asquenazí, perteneció a una generación profundamente marcada por el trauma del destierro de los judíos de España en 1492. Su principal maestro, Moisés Cordovero (1522-1570), era 
sefardita, así como otros muchos de los integrantes de su escuela. No escribió nada:

sus enseñanzas fueron recogidas por su discípulo Hayim Vital (1542- 1620).

Según Gershom Scholem, la Kábala del siglo XVI fue la respuesta del

judaísmo a la expulsión. Esta experiencia provocó que los kabalistas hicieran del

exilio su principal motivo de reflexión, intentando otorgarle una dimensión y un

sentido ontológicos ${ }^{43}$.

La doctrina de Isaac Luria podría formularse a partir de la enunciación de una

pregunta: ¿cómo pudo Dios crear el mundo ex nihilo, de la nada, si no existía la nada,

pues todo estaba ocupado por la infinita plenitud de lo divino? El primer paso tuvo

que ser el de la creación de la Nada, es decir, de un espacio que no es Dios ni ninguna

clase de existencia, sino tan solo la ausencia. Y esto sucedió en el Tsimtsum ${ }^{44}$, que en

el lenguaje kabalístico significa retirada o retracción. Por otro lado, el profesor

\footnotetext{
${ }^{43}$ Esta teoría ha sido últimamente rebatida por investigadores como Moshe Idel, quien en su obra Kábala. Nuevas perspectivas arguye que Scholem carece de elementos concluyentes para hacer una asociación directa entre la expulsión de 1492 y las ideas desarrolladas por la Kábala de Safed: "La propuesta de Scholem para explicar las características de la Kábala luriánica se basaba en el supuesto implícito de que este tipo de tradición mística encierra innovaciones conceptuales importantes, y que estas deben ser explicadas sobre la base de cambios históricos más que en función de procesos internos; además, ello implicaba un desprecio de los materiales kabalísticos existentes en los manuscritos. Ahora bien, este enfoque parece ser metodológicamente problemático: los textos luriánicos no mencionan nunca la expulsión, como tampoco incluyen concepciones innovadoras de tal magnitud que debamos volvernos, para explicar su origen, hacia temáticas totalmente ausentes en ellos" (pp. 348-349). Sin embargo, nuestros poetas acceden a la Kábala a través de las obras de Scholem, cuyas tesis se consideran como muy acertadas.

${ }^{44}$ En hebreo, el significado genérico de la palabra es "estrechez", "reducción”, "limitación”, “concentración" o "condensación". La teoría del Tsimtsum deriva de las enseñanzas de Luria y se puede resumir como el fenómeno de contracción divina con el objetivo de permitir la creación. Antes de la creación del mundo, Dios llenaba todo el espacio. Cuando Dios quiso crear el mundo, retiró su luz. Esta luz sufre de numerosas Tsitsumim (restricciones); cada Tsimtsum es una disminución gradual de la luz divina y una adaptación a la capacidad de recepción de los seres creados. El reshimu es el residuo que quedó de la luz infinita que volvió a Dios mediante el Tsimtsum. En un segundo tiempo, Dios envía a ese receptáculo (reshimu) un hilo de luz, un kav, que en su desarrollo va a constituir diez círculos. Esta etapa de la Creación se llama Igulim (círculos). El mundo de los Igulim es también llamado el mundo del Tohu (mundo caótico). Las luces divinas tienen una intensidad desmesurada en relación con la capacidad del Keli (recipiente), que son las sefirot de los Igulim (en círculos concéntricos). Hay, entonces, una rotura de los receptáculos que no pueden contener esta luz intensa. Esto es el estado de Shevirat Hakelim (rotura de los recipientes). El kav es el rayo de luz divina emanado de Dios dentro de la "noche" del vacío creado por el Tsimtsum con el punto del reshimu en su interior. Este rayo de la "mañana" es la revelación de la inmanencia de Dios en la creación.
} 
Stephen Hawking describe la Creación planteando que esta ocurre fuera del campo de las leyes conocidas de la física. Los kabalistas previos a Luria sostenían que el mundo había emergido en el momento en que Dios quiso derramar su poder supremo y todopoderoso fuera de su propia existencia del yo, en el espacio infinito. Luria, incluso, censura y enmienda ese concepto: si Dios está en todos las esferas, ¿pueden existir entonces satélites, cuerpos sólidos, estrellas, unidades que no son Dios? Según Luria, lo que Dios hizo fue retirarse de Él mismo, recogerse, concibiéndole espacio al Universo.

Gershom Scholem ${ }^{45}$, uno de los exégetas de Luria, ha discurrido que también ese acto divino puede ser entendido como un autoexilio. El Tsimtsum, entonces, advertiría el exilio que Dios hace de Él mismo para entreabrir un lugar al Universo, para manifestarse a través de él. Según Vital, en Ocho puertas, "todos los días la luz sale de Dios y regresa a Dios. Sin esa tensión perpetua, sin ese movimiento incesante que va abriendo y cerrando grietas en el espacio, el mundo no existiría ${ }^{46 \%}$.

“El primer acto de Dios no fue, por tanto, de revelación o expansión sino de ensimismamiento, un recogimiento" (Scholem, Los orígenes de la Cábala 45). Y conviene notar que tal retiro no conduce a liberar las orillas — una zona secundaria y adyacente - sino que se rasga un espacio en el corazón mismo de la Divinidad: es el centro el que se hace circundante; es en ese punto crítico, escogido, donde tiene el mundo su lugar. Quizá así podría entenderse mejor una célebre cita que plantea que: “Él (Dios) es el lugar del mundo, pero el mundo no es su lugar” (Midrash Rabá,

\footnotetext{
${ }^{45}$ Es uno de los académicos que más ha estudiado a Luria. Scholem es acusado de no prestarle atención a otros kabalistas, solo a Luria, y de ahí toda su teoría.

${ }^{46}$ Rabí Isaac Luria Ashkenazi está considerado como el pensador más profundo del misticismo hebreo. Se le conoce también con el sobrenombre de Arí zal'hakadosh. Es interesante destacar que el Arí no escribió nada. Su sucesor, Rabí Jaim Vital, escribió — dictado por el propio Isaac Luria - todo su pensamiento. Los libros son llamados hoy en día Las escrituras del Arí. Entre ellos destacan Árbol de la vida y Ocho puertas.
} 
Génesis 68:10). El Infinito hizo un espacio en su seno para acoger a la Creación, y al mismo tiempo, lo creado dejó de pertenecerle: se convirtió en una isla.

“Dios es el primer exiliado de la Creación: se confina a Él mismo de su totalidad hacia una profunda reclusión" (Idel, Cábala: nuevas perspectivas 82). Vista de esta manera, la idea del Tsimtsum es el símbolo más profundo del exilio que se pueda concebir. Los kabalistas van más allá y afirman que en todo intento de creación humana, que no es más que un descolorido reflejo del primer ímpetu creador, se recorre el mismo camino: cada resplandeciente y original acto de emanación va precedido de un retraimiento, de una restricción.

Según Barnatán, la primera labor del artista es, pues, la creación de un espacio vacío, fuera de él, en el que pueda aparecer su obra. Y la Nada no sabría ser mera negación. En un sentido místico, la $\mathrm{Nada}^{47}$ alcanza el máximo grado de realidad y de existencia. Esa Nada de donde todo afloró o brotó es desconocida e inefable; solo descendiendo a sus profundidades se encuentra lo divino.

Cuando los kabalistas quieren referirse al Dios oculto (por contraposición al Dios que podemos conocer a partir de sus atributos y la Creación), al que denominan

\footnotetext{
${ }^{47}$ Así define G. Scholem en Conceptos básicos del judaísmo: Dios, Creación, Revelación, Tradición, Salvación el concepto de la Nada. La creación de la Nada es expresión de la absoluta libertad del Creador, capaz de dar el ser a algo distinto de sí mismo. Para Dios es posible lo que a ningún ser humano o angélico le es dado: Él crea de la pura Nada. Su libertad, que al tiempo es plena autarquía, su estar-solo-referido-a-sí, le permite "llamar a la Nada" — como dice en el siglo XI Shelomó ben Gabirol, Avicebrón en su poema hebreo "La corona del Rey" - y hacer brotar de sí al ser. Pero esa llamada a la Nada tampoco es materia de la Creación: crea por la palabra, no de la palabra, como precisa la correcta formulación del concepto. La libertad de Dios, tal como la entendían los teólogos del monoteísmo posbíblico, se manifiesta precisamente en que no está condicionada por nada. No hay ninguna materia originaria ya disponible previamente, por muy informe que se la conciba y por mucho que se la reduzca a un mínimo de ser que condicione el proceso, en cuanto que él la domina y le da forma. En el mito, la Creación domina en el dar forma. En la creación de la Nada no hay nada que dominar ni informar. Con soberana libertad hace existir algo que no es Dios mismo ni proviene de la misma sustancia de Dios, o, para emplear aquí la definición del concilio Vaticano I como formulación clásica de esa doctrina, "es el acto libre por el que Dios ha creado de la nada todas las cosas, tanto espirituales como materiales, en toda su sustancia". Nada creado o increado se presupone como materia de tal creación. Los teólogos medievales, judíos y cristianos apelaban en igual medida a una explicación de la palabra hebrea para crear, bara, que se usa en el primer versículo de la Torá y que según ellos significa precisamente eso: "crear de la nada".
} 
En soph (literalmente, "sin fin") dicen que permanece eternamente incognoscible en las profundidades de Su Nada. Por tanto, la ausencia encarna la omisión y la carencia, la escasez, la inexistencia, el abandono, el agujero de la profundidad y la inexistencia, pero también la fertilidad: la posibilidad de engendrar y procrear algo distinto de todo lo existente. Según el mito judío, "la Creación es un rayo de luz proveniente de Dios que inicia la aparición de ese vacío primordial” (Idel, Filiación y misticismo judío 31). Únicamente a partir del paso — aunque sea efímero — por la nada, puede tener lugar la creación de lo ajeno, de aquello que, aunque emane de uno mismo, necesita un espacio propio.

Marcos Ricardo Barnatán reconoció la correspondencia entre las ideas de la Kábala de Safed y su propia poética: "La Kábala ha determinado formas radicales en mi concepción poética. Si me preguntas cuál es mi concepto de creación, yo te responderé según la visión de los kabalistas del siglo XVI” (La Kábala: una mística del lenguaje 139).

Tal declaración de intenciones quedó concretada cuando expresó que la idea de la Creación ex nihilo es una estética adoptada por él como escritor. Lo que explica Luria es que todo era Dios, y mientras Dios lo ocupaba todo, no había espacio ${ }^{48}$ para la Creación. Lo mismo sucede, pero en diferente escala, con los creadores artísticos.

El concepto de Tsimtsum sobrepasó el contexto de la escuela de Safed y empezó a formar parte de las discusiones teológicas posteriores. Las interpretaciones que ha recibido pueden agruparse en dos grandes categorías: las literales, para las que el Tsimtsum es una contracción que provocó la separación entre la Divinidad y el

\footnotetext{
${ }^{48}$ En La Cábala y la crítica, Harold Bloom pregunta: “¿qué significa "limitación” en el contexto de la poesía?" (74). Y más tarde explica lo que ese vacío representa para él: "Para comenzar significa una pérdida de significado, incluso una consumada carencia de significado, un sentido de que la representación no puede lograrse plenamente o de que la representación no puede colmar el vacío a partir del cual surge el deseo de poesía” (74).
} 
mundo finito, y las alegóricas, para las que no existe ningún retiro: se trata solo del enmascaramiento u ocultamiento de la presencia del En soph en el Universo.

Dios es manifiesto u ostensible precisamente porque se ha limitado. Mientras que en el pensamiento de Luria el Tsimtsum se refiere al retiro de un determinado espacio, en otros textos el término nombra la concentración de lo divino en un lugar preciso. El jasidismo ${ }^{49}$ se sirve de ambos significados. Dios, contrayéndose, va al encuentro del hombre. "Su retiro, al crear una distancia, hace posible el contacto: el interés y el conocimiento, pues sin un espacio abierto, no hay acercamiento ni mirada posible" (Pinjas, Comentarios 93), al igual que los ojos de la madre no pueden ver a un niño del que no se ha separado, que está por nacer. El establecimiento de unos límites es condición indispensable para la existencia de cualquier nexo.

El Tsimtsum es percibido como punto de partida, "un proceso que permite al hombre desarrollar la capacidad de atraer lo divino hacía Él. Dios se contrae en las letras del texto sagrado, que actúan como receptáculos que acogen su existencia" (Barnatán, Antología 23). Su aplicación al ámbito de la interpretación de las Escrituras supone una aportación crucial:

El comentario de la Torá y la innovación en su exégesis son reseñados como la atracción de la infinidad divina hacia el mundo y la Creación, así, de un acto de Tsimtsum. Cuando el exégeta se acerca a las Escrituras, despierta en ellas una forma de lo divino, retraída y limitada, que posee las dimensiones de lo humano: una fuerza oculta que habla misteriosamente, pero en la lengua de los hombres (Reseñas de reseñas: el rabino no cree en Dios, 85).

\footnotetext{
${ }^{49}$ El movimiento surgió en Europa oriental, específicamente en Bielorrusia y Ucrania, en el siglo XVIII, fundado por el rabino Ba'al Shem Tov Israel ben Eliezer, conocido como el Ba'al Shem Tov. Este tipo de judaísmo se divide en varios grupos, dentro de las cuales encontramos a la de Breslov o Breslev (Ucrania), Satmer (Hungría) y la de Jabad Lubavitch (Rusia), entre los más expandidos por el mundo entero. Antes de la II Guerra Mundial, el grupo más grande era el de Gur (Polonia) con alrededor de 250.000 miembros. También se destaca los Jasidim de Breslov, seguidores de Rabino Najman de Breslov
} 
En la labor interpretativa — de la que venimos hablando como impulso de la creación poética-, también se puede advertir un movimiento de retracción inicial e ineludible. El maestro jasídico Rabí Najmán de Braslav (1772-1810) acuñó la expresión "Tsimtsum del espíritu" para referirse a la "ignorancia necesaria" a la hora de acercarse a las Escrituras.

Cuando uno desea crear sentidos nuevos, debe restringir su saber (literalmente: hacer el Tsimtsum en su espíritu); es decir, hacer el vacío, no sumergirse en consideraciones previas conocidas que enredan su espíritu y no son necesarias para innovar. Debe hacer, según Najmán, como alguien que no sabe, y solo entonces podrá innovar sentidos nuevos progresivamente, en $\operatorname{orden}^{50}$.

El hombre debe retirarse a él mismo para poder acceder a su propio ser. Tal paradoja se encuentra en el corazón de la tarea poética y enlaza con el perfil gramatical de la duda o con la incógnita, que traslada a la apertura máxima, invitación esta a la objeción y al precipicio. La pregunta crea la disponibilidad y se sitúa en el mundo de la vacilación e inseguridad, del deseo o el diálogo; en cualquiera de esos casos, establece una distancia.

La teoría del Tsimtsum llamó la atención de Marcos Ricardo Barnatán por su gran carga poética. Es un concepto que reflexiona sobre la nada, sobre la ausencia y sobre la presencia, convirtiéndolas en metáfora de todo proceso de creación humana. Y así lo expresa la voz poética en su poema Hoти-Humus:

Ante la nada adánica el vacío reinaba. La blanca silenciosa NADA que la letra llenó Con el negro de Adán

\footnotetext{
${ }^{50}$ Concepto desplegado por Rabí Najmán de Braslav y aludido en más de una ocasión en Los cuentos del rabi Najmán de Nejama Lapidus de Sager.
} 


\section{NADANADA ${ }^{51}$.}

En este sentido, es importante ver cómo la mística judía otorga al lenguaje un lugar supremo. Al hablar o escribir el hombre roza la profanación, pues utiliza la misma herramienta de la que Dios se sirvió para crear al mundo. La Kábala advierte en el lenguaje la tarea suprema de reflejar, de ser una manifestación directa de la divinidad. Barnatán entiende la poesía como una actividad capaz de dar vida, liberando al lenguaje de la mera función de comunicarse. "Dios, para crear el Universo, se redujo dentro de las letras de la Torá" (Scholem, La Cábala y su simbolismo 71), que es una de las interpretaciones del acto del Tsimtsum. Por tanto, este acto es una buena explicación de por qué la Kábala y la poesía tienen una visión similar en cuanto a lenguaje y escritura se refieren.

La especial atención a la lengua y a las palabras forma parte tanto del kabalista como del poeta. Ambos toman en cuenta las etimologías, y los múltiples significados ${ }^{52}$ de determinados conceptos claves, asumiendo la idea de que la penetración en el lenguaje es la fuente de la poesía y del discurso crítico. La palabra se convierte en el motivo predilecto de atención y reflexión. Las letras contienen significado; sus trazos están llenos de misterio y sentido. La Escritura está viva por el

\footnotetext{
${ }^{51}$ En el poema aparece este juego de palabras de forma circular, dando al lector la idea de un ciclo sin principio ni fin: NADA- ADAN.

52 “El doctor de la Ley y comentador está ejerciendo, pues, la función que le es propia: concretar la Torá en el punto y hora en que él está, hacerla aplicable, y además, dar a esa concreción específica una forma transmisible a las generaciones venideras. La Kábala posterior acuñó la tesis, ampliamente aceptable, de que la Torá presenta a cada judío un rostro especial y específico, solo comprensible para él, y que cada uno solo realiza propiamente esa determinación cuando percibe ese rostro destinado a él y se incluye en la transmisión" (Scholem, Conceptos 92).

Por otro lado, en La Cábala y la crítica, Bloom apunta que, cuando uno declara que una obra contemporánea es un logro permanente, clásico, la hace padecer una asombrosa, manifiesta e inmediata pérdida de significado. De su carácter tardío uno ha hecho un carácter temprano, pero solo rompiendo la ilusión de la modernidad, que es la ilusión de que la literatura puede liberarse de la literatura. Toda canonización de un texto literario es un proceso que se contradice a sí mismo, ya que al canonizar un texto uno le aplica tropos, y eso significa que lo estamos leyendo mal (100).
} 
rastro de Dios, la poesía es percibida también como huella de lo ausente. Es un residuo, un eco, lo que queda de un esplendor del que no se guarda memoria.

El ser humano pasa casi toda su vida (si no toda) en esa fase: considerando la necesidad de vivir en las preguntas. El niño, embebecido por la sorpresa, siempre ama las preguntas. Las manifiesta, las expresa, son la base de su pensamiento, la única forma de acercamiento a él mismo y de conexión con el mundo que le rodea. Muchos adultos creen en la conveniencia de superar esa etapa. Esa idea es desacertada, pues ningún conocimiento, avance científico o creación artística sería posible sin ese anhelo por lo desconocido. Amor, y no interés o curiosidad.

La carencia, como fuerza primera, es seducción enorme por el inmenso agujero al que se abre la vida. El amor a Dios, entre los místicos judíos, pertenece a esta misma índole. Es deslumbramiento y seducción por lo desconocido, pasión de la invisibilidad, placer resbaladizo y burlón. Es presencia que se presiente, se vislumbra, pero que nunca se desvela en forma de respuesta. Es el milagro de la fascinación, del que la Divinidad necesita para revelarse cercana. "La actividad poética parte también de una aceptación de la ignorancia: vacío necesario para que nazca el poema, del que, en rigor, el poeta no sabe nada" (Alonso, Poesía y estilo 34). Así se muestra en "Séquito memorable":

Todo tiniebla

Sibil oblicuo ardo

Ojo turbio

Vi a Urizén sobre el Atlántico

Señales disecadas

A la sombra sátira

De la piedra

Estigma arisco

Brota y riñe

Letal

Abismo

Originado a mis pies

No turba 


\section{No borra la Universal \\ Memoria \\ Labrado séquito descubro \\ En el cóncavo espacio.}

El poema es una criatura desorientada, que aparece por sorpresa y trata de apresar lo más efímero. Fracasa en su intento. "El texto final no sabe ni comunica nada: solo 'es', se manifiesta, surge misteriosamente y solamente logra comprender que no es único en esa experiencia" (Alonso, Poesía y estilo 61).

El intérprete y el artista han de compartir ese pequeño lugar, ese punto en el que situarse ante la vida. Hacer un vacío en la mente, liberarla, escribir y leer los textos como si fuera la primera vez. Pues únicamente así, desarropados, desposeídos, podrán acercarse a la indeterminación necesaria, a la palabra absoluta, que está todavía sin trascendencia en ella misma, pero abarrotada de importancia y prominencia. La Palabra inicial o antepalabra no se señala aún porque no es de su propiedad el significar sino el manifestarse. Una vez ya mencionada la palabra, entonces emerge una relación amorosa entre el texto y su intérprete, entre el poeta y sus palabras. Ambos se conocen íntimamente, con exclusividad absoluta. Son el uno para el otro.

La poesía precisa de la misma voluntad de ignorancia, de un saber encontrarse ante el papel en blanco en un perpetuo estado de simplicidad, alejado de las formas ya hechas y hasta de la propia retórica ${ }^{53}$, y de este modo, "descubrir a las palabras frente a frente, con una mirada todavía capaz de asombro, inocencia y lucidez" (Anderson, Los orígenes de la postmodernidad 21). Marcos R. Barnatán, en Dictado por los

\footnotetext{
${ }^{53}$ Véase más en Paúl Valery, Carta sobre Mallarmé.
} 
antiguos sabios, nos comenta sobre el lenguaje poético, sobre el concepto de poesía y sobre el papel que juega el poeta en todo este andamiaje.

Un lenguaje puede ser maleficio. El encantamiento, un recurso válido para acceder a la suprema armonía. Como el frío de la rana colma el ardor de la fiebre.

Un lenguaje poético vencedor de la humanidad arcaica porque acepta lo nuevo y lo irreversible. El poeta es un instrumento-estructurador: el miserable intermedio.

Entre el orden supremo y el caos circundante. Su ritual es infinito, incoherente, disperso, ambiguo, cruel, primitivo. Una fe superior le guía, le concede abolir el espacio real. Su meta es cosmogónica, su origen caótico. Al construir remeda el génesis inicial. Retoma una mitología abismal. Poesía es prohibición. Voluntad antihistórica atemporal. Poesía es revelación ${ }^{54}$.

Tan perfecto fue el trazado de la Ley que los Antiguos Sabios la olvidaron.

“Un lenguaje puede ser maleficio" (1). Así es como empieza Dictado por sabios. Aquí la poesía parece definirse a partir de la firmeza de un pesar, de una angustia. No es una realidad que exista con independencia del ser humano: es el hombre en movimiento, con sus cambios, quien crea el tiempo. Y todos los esfuerzos de variación y creatividad nacen, una vez más, de la distancia entre Dios y el mundo: son una voluntad de restauración y trascendencia. El tiempo empieza, para el hombre, con la expulsión del Paraíso ${ }^{55}$, con la conciencia del dolor. Y su curso está marcado por los anhelos, por la búsqueda de lo ausente. El motor de la historia es, en realidad, un cuestionamiento constante, un mirar hacia delante guiado por la luz del deseo. En Nitimur in Vetitum ("Nos esforzamos por lo prohibido") se propone esa área

\footnotetext{
${ }^{54}$ El subrayado no es mío: así es como aparece en el poemario El oráculo invocado de Marcos Ricardo Barnatán.

${ }^{55}$ Recuérdese que en el judaísmo se cree que fue el hombre quien expulsó a Dios del Paraíso con su comportamiento. Una vez desterrado del Paraíso, la parte femenina de Dios se desune para acompañar a los hombres en su autoconfinamiento. Su condición es, por tanto, el desarraigo, el desconsuelo y la angustia, pues no podrá completar la unión divina mientras no se haya producido la redención del mundo. Al mismo tiempo, es la única capaz de mostrar el sendero de vuelta al Edén, advierte el Zohar.Para más información, véase el Zohar. Revelaciones del Libro del Esplendor, selección de Ariel Bension, p. 33.
} 
predilecta para conseguir ese intenso conocimiento de los límites del hombre, y al mismo tiempo, se intenta acercar el lenguaje a lo innombrable. Ese abandono abre un camino, y a su vez esconde algo. Así se presenta el poema:

Clara es la orden

Como en Egipto las dinastías

Abatirás a tus enemigos

$Y$ del árbol vencido la sabia

Misteriosa ciencia comerás.

No retrocedas ante la muralla muerta

$\mathrm{Ni}$ ante la imagen falaz de lo vedado

Cruza la tempestad funeraria

Y verás el ritual del arsénico

El círculo

\section{Los tambores}

\section{La fórmula.}

El universo resucita en la unión

Y las cabezas de las serpientes

Ofrendan su incendio y su caída.

Barnatán reconoce que en una situación de exilio es donde la palabra se

desnuda de todo sus atuendos, se aproxima delicadamente al silencio, y es donde trata de obtener el sentido.

La expulsión de los judíos de España suscitó en la Kábala un tiempo de desconcierto en el que se mezclaron, por una parte, el dolor colectivo ante la calamidad, y por otra, una incontenible justificación apocalíptica de los hechos ${ }^{56}$. El año 1492 marca el fin de la antigua Kábala, que había tenido su centro, en la Gerona

\footnotetext{
${ }^{56}$ Véase Las grandes tendencias de la mística judia. Este volumen se compone de nueve conferencias pronunciadas por Gershom Scholem con ocasión de su visita, en el año 1938, al Jewish Institute of Religion de Nueva York. En la sexta conferencia él expone de una forma muy consistente la hecatombe que supuso el exilio, a finales del siglo XV, de los judíos de España. Además, hace inusitadas referencias a figuras como Cordovero y Luria.
} 
medieval. Los kabalistas de la expulsión pretenden una minuciosa interpretación apocalíptica de las Sagradas Escrituras y de los Salmos. "La Kábala nueva, surgida de ese Exilio y ese Éxodo, comenzó a difundir que la vida de los judíos en paz solo era posible en Israel" (Scholem, La Cábala y su simbolismo 36), reavivando de esta manera el espíritu sionista - mesiánico, como dicta el segundo verso del poema anteriormente citado:

Clara es la orden

.........

Abatirás a tus enemigos

$Y$ del árbol vencido la sabia

Misteriosa ciencia comerás (1, 3-5).

Este espíritu nunca se había apagado en el alma judía. Las características asumidas por la nueva Kábala exigieron abandonar el carácter elitista que la Kábala había tenido, y así lo plantea el poema: "No retrocedas ante la muralla muerta/ Ni ante la imagen falaz de lo vedado" (6-7). Era necesario que los kabalistas lograran el arrepentimiento masivo del pueblo exiliado para lograr su renacimiento (llegada del Mesías) ${ }^{57}$. El Exilio sirvió como catalizador por el cual se accede al arrepentimiento y a la redención.

Al final del poema anteriormente citado, se menciona la ofrenda como una vía capaz de abrir o sellar un mundo, de olvidarlo o hacerlo presente. La llave que tiene el kabalista entre las manos cuando interpreta los textos, "la puerta que lo separa y lo comunica con esa Divinidad concentrada y oculta; que ha hecho un hueco en su interior para otorgarle un lugar donde vivir para que el mundo sea" (Aviezer, En el principio 72 ).

\footnotetext{
${ }^{57}$ Véase The Messianic Idea in Israel by Josef Klausner. Además, se podría revisar The Messianic Concept in the Old Testament and Later Judaism, de Sigmund Mowinckel, donde expone un análisis mitológico e histórico de la formación de la fe mesiánica (Oxford, 1956).
} 
Se puede concluir que el espacio vacío, de apertura, que aparece entre Dios y el mundo, entre el hombre y las cosas, el lenguaje y el sentido, el intérprete y el texto o el artista y su obra es el lugar de la realización del Universo (en vocablos religiosos), y también el de la efímera creatividad humana.

"Dios es el único virtuoso de la creación ex nihilo, y la creatividad de los mortales se concibe como su limitado correlato en la tierra" (Heschel, Dios en busca del hombre 101). El hombre, ser hecho a imagen y semejanza de la Divinidad, recibió el lenguaje — herramienta creativa por excelencia — y la capacidad de fundar diversas manifestaciones culturales, no a partir de la nada, pero sí combinando o transformando, de forma novedosa, lo ya existente. Un precipicio se abre entre la creación humana y la divina, pues la primera está sujeta a unas normas: las leyes del mundo, no elegidas, que actúan como acotaciones y difícilmente pueden ser transformadas. No obstante, algunos kabalistas medievales creían en la posibilidad de competir con Dios en sus obras, aunque esto conllevara riesgos sorprendentes. Prueba de ello sería el mito del Golem ${ }^{58}$.

Por otra parte, el prototipo de la creación humana se relaciona en sus orígenes con una criatura - aún por precisar - que se mueve entre la existencia y la inexistencia, que posee el poder de desarrollarse pero aún no es. Se establece, entonces, una íntima conexión entre el concepto de la Nada cual paso previo de la creación: la potencialidad de vida, aún informe. En la poesía, es la palabra poética que está por decir, que sugiere sin alcanzar el punto de la máxima determinación, la “palabra fertilizada o preñada" a la que se refiere Marcos Ricardo Barnatán en su poema "Piedra de sol/edad":

\footnotetext{
${ }^{58}$ La palabra Golem aparece una sola vez en la Biblia (Salmos, 139:16), y de ese pasaje proviene el uso talmúdico del término como algo informe e imperfecto. En el empleo filosófico medieval se refiere a la materia sin forma. Véase Gershom Scholem, Grandes temas y personalidades de la Cábala, p. 172.
} 


Como un ciego
nazco en otro
y prosigo sin cuerpo
escribo a solas
no hay nadie
piso mi sombra
en busca de un instante
escritura en el desierto
el ser sin nombre
se contempla en la nada
sol de soles
nunca somos
sino vértigo y vacío
sol

Se puede concluir, llegado a este punto, que el Universo de la creatividad está indisolublemente unido a la aparición de una zona intermedia en soledad, un lugar para el juego hospitalario, afable, agradable y vacante.

\subsubsection{De la nada a la existencia: lo manifestado}

La idea de la creación ex nihilo formulada como tal no aparece en los textos judíos hasta la Edad Media. El único precedente encontrado en la literatura judía antigua es una ambigua sentencia hallada en la introducción del Séfer Yetsirá: "Él [el Creador] formó algo actual a partir del caos y convirtió lo que no es [eino] en lo que es [yeshmo]" (117). Durante el Medievo se acuñó el término ayin para referirse a la Nada.

Maimónides reconoce el concepto, la idea de la creación ex nihilo. La Nada ${ }^{59}$ para Maimónides era lo no existente, y en ningún caso podía atribuirse a Dios tal

\footnotetext{
59 “Los cabalistas españoles del siglo XIII defendieron la tesis de Dios como la pura Nada sin que ninguna instancia se les opusiera. Así, pues, los cabalistas podían desarrollar su doctrina sin temor de que una formulación demasiado atrevida les supusiera un inmediato conflicto con la autoridad, ya que los místicos judíos estaban en una situación más favorable que los místicos cristianos. Lo que para Escoto Eriúgena era el mundo de las causas primordiales era para los cabalistas el mundo de las sefirot. La mayoría de los cabalistas enseñaban que la verdadera creación de la Nada consiste en el surgimiento de Hojmá: Sabiduría de Dios" (Scholem, Conceptos 64).
} 
condición, puesto que Su existencia es totalmente distinta de cualquier cosa que pudiésemos concebir: Dios reside y se halla, pero no a través de la existencia. La negación no sirve, por tanto, para denominar lo infinito. La teología de Maimónides fue recogida por los místicos medievales, y estos la hicieron suya.

Un nuevo concepto de la Nada comenzó a abrirse camino en ciertos círculos kabalísticos a partir del siglo XI. Este tema tan sugerente está relacionado con el contenido de un escrito de Salomón Ibn Gabirol ${ }^{60}$, a quien Marcos Ricardo Barnatán dedica un poema.

Los místicos medievales a menudo tomaban imágenes y términos de la poesía hispano-hebrea, que gozaba de gran popularidad. Valga el ejemplo para subrayar que las relaciones entre Kábala y poesía son antiguas y se producen en ambas direcciones, remontándose a los orígenes de la doctrina.

El poema "Kéter Malkut" de Gabirol, titulado en español como "La Corona real" o "Corona del reino", es el poema más laureado del autor, ya que en él logra conciliar el saber científico con la erudición filosófica de la época. Su gran ímpetu y su belleza lo hacen merecedor de tal valoración.

Gabirol hizo un tipo de poesía religiosa mucho más personal, y para ello uso una lengua hebrea muy modernizada. Los hermosísimos metros silábicos sefarditas exhibidos en su poesía han hecho que sus poemas religiosos sean usados incluso hoy en día para Yom Kippur, Día del Perdón.

El Kéter Malkut es una condensación entre las creencias judías y la ética neoplatónica. Por ello, Gabirol se vale de un conjunto de nociones e ideas que se tenía acerca de los astros, de sus posiciones y de sus movimientos en el mundo árabe.

\footnotetext{
${ }^{60}$ Ibn Gabirol es el máximo exponente del neoplatonismo en la filosofía hebrea. Escribió tres obras donde aborda problemas éticos; la tercera es de carácter ontológico.
} 
Este poema de Ibn Gabirol dice: "Tú eres sabio, y de tu sabiduría hiciste emanar una voluntad determinada, como obrero y artista, para extraer el ser de la nada, como se extrae la luz que sale de los ojos; sacaste de la fuente de la luz sin pozal, e hiciste todo sin ningún instrumento" (Fuentes judías: leyendas del Talmud y del Midrash 89).

Dios es equiparado, ya en el segundo verso, con un asalariado o un artífice. La luz que se desborda de los ojos, enigmática, alumbra el mundo: es como el ser que se origina del vacío. La Divinidad “extrajo el resplandor de un pozo estrecho y con él creó y dio vida. Todo a través de la intención gracias a una secreta sabiduría y enorme deleite" (Séfer Yetsirá 63).

En el Zohar, ayin se identifica con la primera sefirá: Kéter, la Corona. Las sefirot, recordemos, son emanaciones a través de las cuales el En soph, la Divinidad inescrutable, se manifiesta, y se convierte progresivamente en el Dios de la Creación ${ }^{61}$.

La primera de ellas es Kéter — la más cercana al infinito incognoscible: los kabalistas la utilizan para referirse a la manifestación de la voluntad primordial—, y la última Maljut: el reino, que es la forma más próxima al ser humano. "Dado que

\footnotetext{
${ }^{61}$ Moshe Idel afirma que, desde comienzos del siglo XIII, a la pregunta por la naturaleza de las sefirot se le ha dado tres respuestas principales: "En primer lugar, la teoría de que las sefirot forman parte de la naturaleza divina y participan de la esencia divina [...]; en segundo lugar, la teoría de que las sefirot no son divinas por esencia, aunque estén estrechamente ligadas a la Divinidad, y son, bien sus instrumentos para crear y gobernar el mundo, bien receptáculos del influjo divino por los que este se transmite a los mundos inferiores; en tercer lugar, la idea de que las sefirot son la emanación divina en el seno de la realidad creada, constituyendo, por decirlo así, el elemento inmanente de la Divinidad. Vale aclarar ciertos conceptos aquí un tanto ambiguos. Sefirot se refiere al modus operandum de Dios después de que se produce en Él la contracción, que se ha comentado anteriormente. Por esa razón, las sefirot son diferentes: hay diferenciación entre ellas y donde se encuentra una sefirot no existe la otra. Dios quiso traer diferenciación al mundo, variación, a pesar de ser Él la unidad perfecta. Cabe la pregunta: ¿cuál es el objetivo de esta Creación variada? Poner las diferentes piezas del puzzle juntas, y de esta forma, lograr la venida del Mesías, trayendo el cielo a la tierra y así lograr la unicidad.
} 
[Kéter] es el catalizador de todo ser, pero todavía no es una cosa en ella misma, también se le llama, en el lenguaje paradójico tan propio del Zohar, Nada" (Freeman, Trayendo el Cielo a la tierra 122). Para el Zohar, Kéter o Nada está eternamente presente junto al En soph, pero no se identifica con Él. Y es muy importante notar que a la primera sefirá también se la denomina en los textos zoháricos Ehyeh: “yo seré"62, en referencia a la revelación bíblica que recibió Moisés: "Yo soy el que soy” (Ex.

3.14). Sin embargo, siguiendo a Martín Buber ${ }^{63}$, la sentencia no debe entenderse tanto como muestra de opacidad (palabra de un Dios que quiere esconderse), sino como manifestación de la presencia divina en el mundo:

No creo en una autodesignación de Dios, en una autoclasificación de Dios ante los seres humanos. La palabra de la revelación es: "Yo soy el que soy". Lo que revela es lo que revela. El ser es, nada más. La eterna fuente de la fuerza sale a chorros, el eterno roce persiste, la eterna voz suena, nada más (El humanismo hebreo, 197).

El ser y la Nada se acercan en la sefirá Kéter. La Nada no representa, en este contexto, mera negación o ausencia, sino robustez y energía máxima. Ehyeh es apertura hacia lo desconocido: aquello que "llegará a ser”, según otra posible traducción de Ehyeh, o que "hace ser", con un sentido causativo.

Los kabalistas encontraron, gracias a su continua labor hermenéutica de actualización del texto sagrado, una atrayente convergencia con el libro de Job en su concepción de la nada primordial. Analizaron algunos versículos del poema bíblico en

\footnotetext{
${ }^{62}$ El sistema verbal hebreo, como el de las otras lenguas semíticas, no está construido sobre la categoría del tiempo sino sobre la del aspecto. De este modo, Ehyeh es la forma del verbo ser en primera persona del singular del imperfectivo, lo que en castellano puede traducirse por un futuro, un presente, o incluso un pretérito imperfecto: cualquier tiempo de aspecto imperfectivo, es decir, que exprese una acción no acabada (o, según otras teorías lingüísticas, una acción vista desde dentro, con participación anímica del sujeto).

${ }^{63}$ Filósofo, teólogo y escritor austríaco - israelí. Véase ¿Qué es el hombre? de Martín Buber, donde se profundiza sobre la manifestación de Dios en el mundo.
} 
los que aparece la palabra ayin $^{64}$, interpretándolos de acuerdo con sus nuevos planteamientos.

Es necesario recordar, en primer lugar, que ayin en hebreo bíblico significa tanto "nada" como "dónde". Valga destacar, en el libro de Job, una pregunta retórica: “Y la sciencia ${ }^{65}$, ¿de adónde será fallada?": כחהו _ יאמ ה אצמת (Job 28. 12).

En el contexto talmúdico, el significado es que la sabiduría — es decir, las palabras de la Torá— se hallan en alguien que se ve a sí mismo como inexistente. Este concepto es representado en el versículo por la palabra ayin.

Los kabalistas del siglo XIII convierten esta pregunta en una fórmula mística: la sabiduría divina alcanza la existencia a partir de la nada. El versículo no es interpretado como un interrogante sino cual un anuncio (aprovechando la ausencia de signos de puntuación en la Torá). Moisés de León se expresa en los siguientes términos:

Dios es la aniquilación de todo pensamiento; ningún pensamiento puede contenerlo. Puesto que ninguna cosa del mundo puede contenerlo, se le llama ayin. Este es el secreto de lo que se ha dicho: "La sabiduría alcanza la existencia a partir de ayin. Algo sellado y oculto, totalmente incognoscible, recibe el nombre de ayin, puesto que nadie sabe nada sobre ello. Del mismo modo, [...] nadie sabe absolutamente nada sobre el alma humana; su estado es la Nada, tal como se ha dicho [Eclesiastés 3:19]: "La ventaja de lo humano frente a lo animal es ayin. Gracias a esta alma, el ser humano goza de una ventaja sobre todas las demás criaturas y la gloria de lo que se denomina ayin" (Rabí Menachem Mendel de Kotzk: A Biographical Study of the Chasidic Master, 29).

La sabiduría surge y se manifiesta a través de la Nada. "Job lo había tenido todo: vivía en un limbo muy cercano al Paraíso terrenal. Su vida era agradable y colmada de bendiciones" (Heschel, Preguntas del hombre a Dios 111). Y en ese

\footnotetext{
${ }^{64}$ Ayin ("Nada"). La Nada para los kabalistas no sería una dimensión de ausencia sino una dimensión a la que la inteligencia humana no puede acceder.

${ }^{65}$ Sabiduría.
} 
estado, se había olvidado de sí mismo: al igual que Adán, no sabía que era hombre.

Lo que tiene lugar en el libro de Job — como bien apunta Marcos Ricardo Barnatán— no es el reconocimiento racional del mundo ni de las leyes de la vida, sino la repentina conciencia de él a través del abandono absoluto. Job "sufre de verse y de descubrirse" (112). Tras haber experimentado la totalidad de la dicha, vive el apogeo del sufrimiento. Llega el momento en que "solo le queda su propia vida, que es el fondo último de la experiencia humana" (115).

Marcos Rircardo Barnatán se fija precisamente en ese instante para escribir su poema "Ha Neelam",66, que forma parte del libro La escritura del vidente y es puesto en boca de Job. La ausencia de lo amado parece ser una secreta compañía. Para Job es Dios, al que se sabe cerca, aunque escondido. Se trata de una presencia desesperada, llena de cercanía, pero también de desamparo:

Y en instante todo está perdido El cuerpo húmedo y nebuloso sangra Radiante brilla en sí mismo Ilumina impasible eternidad. Un movimiento renueva el arco La luz difunde vértigos y fiebres De densas y tempestuosas aguas Surgió ya tallado y príncipe el secreto La misma esencia del profundo abismo.

La voz poética revela que la vida es contraste y paradoja. El poema es manifestación de este acaecer imprevisible. Job atacó directamente la premisa de la justicia universal. No es una idea fantástica e irreal: el hombre concreto y real es sufriente, y esto sucede en todos los tiempos. La voz poética acusa esta angustia, este sobresalto, y lo expresa de la siguiente forma: "Y en instante todo está perdido/ El cuerpo húmedo y nebuloso sangra" (1-2).

\footnotetext{
${ }^{66}$ Midrash místico, escrito casi todo el hebreo, considerado un excelente trabajo alegórico. Su autoría se atribuye a Moisés de León.
} 
"El dolor acerca al hombre a sus fronteras existenciales, abatiendo, desmantelando y prensando el ser para encontrarlo pleno en él mismo; en el fracaso, el ser humano encuentra su grandeza" (Heschel, Preguntas del hombre a Dios 71), porque es desde el desengaño que el hombre se comprende tal y como es: un ser finito, pero con una inscripción de trascendencia que apenas puede vislumbrar desde sus miserias.

Job quiere comprender, desea saber el sentido de su existencia y, particularmente, la razón de su desdicha, y Dios justamente le habla para demostrarle que Job nada entiende ni nada comprende. La verdad de Job es su rebelión. Y Dios mismo, paradójicamente, aplaude su rebelión: “La luz difunde vértigos y fiebres/ De densas y tempestuosas aguas" (6-7). Este es el punto culminante de la paradoja: Job es el hombre más subversivo contra Dios; sin embargo, es el más loado por Él.

El milagro es el acontecimiento que la mente humana no puede prever ni predecir racionalmente. Es el acontecimiento de lo inesperado. Inesperadamente Job pasó de la felicidad a la desesperación; inesperadamente Job pasará de la angustia a la redención. Y esto sucede porque la respuesta de Dios no viene por vía conceptual, sino por vía existencial. Vivencialmente, Job encuentra la salvación que mentalmente no pudo hallar: "Surgió ya tallado y príncipe el secreto / La misma esencia del profundo abismo" (8-9).

Finalmente venció Job. No venció con argumentos. No obtuvo respuestas. Venció por su actitud íntegra y pura, por su fehaciente inconformismo, por su desesperación clamante al cielo. Venció ${ }^{67}$ por su pureza: no se sometió a ningún argumento adulterado. "Vence la rebeldía, el hombre rebelde a su propia rebeldía. Job

\footnotetext{
${ }^{67}$ Véase la visión de Maimónides que expresa que en el tiempo mesiánico se refuerza esa capacidad por las condiciones favorables de paz universal y bondad general opuesta a las ideas mesiánicas expuestas en el Libro del que ha de revelarse, de Abraham bar Hiyá, a comienzos del siglo XII.
} 
no tiene procedencia ni determinación histórica. Job es el hombre verdadero, concreto, competente, de todos los tiempos" (Heschel, Shabbat, su significado para el hombre moderno 92).

Lo que Barnatán manifiesta en toda su obra poética es que, si el espíritu creador se encuentra libre de cualquier tipo de traba o coacción lógica de precepción literaria o humana, no hay razón alguna para no dar rienda suelta a la fantasía, a la imaginación o al sueño. Paralelamente si el mundo real, con sus postulados inamovibles, sus supuestos lógicos y sus encadenamientos tampoco existe, la creación es libre en cuanto a sus producciones y métodos.

Escribir — admite Barnatán — sirve para llenar el vacío de comunicación absoluta y libre. Para el poeta, las palabras y los versos se convocan y en el momento más inesperado acuden: el poema, si tiene lugar, llega. Pero, ¿a qué lugar se refiere Barnatán? ¿Al espacio de soledad no deseada (al que se refiere Job), o tal vez al vacío donde Marcos Ricardo Barnatán, por fin, encuentra cierto sosiego y libertad? El abandono supera a la palabra: representa la mayor incógnita, el último límite de la existencia, ya ilesa.

Quizá por ello Job, en su último abandono, mientras asiste a las palabras del Creador, ya no tiene acceso a la palabra. Es nada, y por lo tanto todavía no hay, en ese instante, nada en él que pueda tomar el camino de la realidad: el ser manifestado.

Quizá las claves del sentir de Job se encuentren en la exploración del impulso poético, tal y como lo concibe Barnatán. En la poesía de este poeta sefardita, "la nada aparece como misterio y como motivo de la acción” (Bloom, Poesía y represión: revisionismo desde Blake a Stevens 47$)$. Se establece una sutil diferencia con el concepto de vacío: la nada configura al vacío para que este sea factible. "El vacío se concibe como un lugar después del caos: la matriz creativa que debe ser 
perfeccionada" (53). La Nada surge, entonces, como un elemento activo, anterior al vacío y a toda existencia, condición de cualquier apertura: es el misterio máximo, la profundidad poderosa, "una mano invisible que moldea lo que todavía no es" (79). Barnatán escribe en otro fragmento del poema "Piedra de sol-edad":

Voy entre galerías de sonidos, fluyo entre las presencias resonantes, voy por las transparencias como un ciego, un reflejo me borra, nazco en otro, mi sombra despeñada me destroza, recojo mis fragmentos uno a uno y prosigo sin cuerpo, busco a tientas, busco sin encontrar, escribo a solas, no hay nadie, cae el día, cae el año, piso mi sombra en busca de un instante, escritura del viento en el desierto, lo que llamamos Dios, el ser sin nombre, se contempla en la nada, sol de soles bien mirado no somos, nunca somos a solas sino vértigo y vacío cara de solitario colectivo.

El poeta, entonces, desterrado en su escritura, abraza el universo de la palabra. "La nada existe antes que el amor, pero el amor crea a la palabra" (Heschel, Dios en busca del hombre 55). La nada es una expresión del amor, del deseo de entregar algo de él a otro, de mirarlo después y dejar que obtenga vida propia. La paradoja de la anterioridad de la nada al amor ocurre, entonces, porque "el vacío existe como contingencia, pero no como acto, no como exteriorización creativa" (Válery, Teoría poética y estética 81 ). Un punto infinito aglomera la existencia y la supresión; en él se halla la capacidad de la luz y del mundo, que en el acto de apertura que realiza todo creador empieza a brillar hacia fuera. Es así como se explica en el Zohar el primer impulso que llevó a la creación del Universo. Se trata de una crisis que ocurre en el En Soph, el Dios oculto, que pasa del descanso y la calma a la Creación. "Esta crisis 
se considera el mayor misterio de la teosofía, y se manifiesta en el instante en el que el Dios oculto se expone y la luz que tiene en su interior se hace ostensible" (Scholem, La Cábala y su simbolismo 72).

Asistimos a un despojamiento definitivo, a una celebración de lo que queda cuando ya todo se ha separado, pues el vacío es también materia, respiración de las palabras, espacio que para nada sirve y que, sin embargo, reúne la posibilidad de entregarse y es fundamento del deseo.

"El poema no aspira a persistir, a colmar, sino a ser un reiterado alumbramiento: vientre que engendra y una y otra vez se vacía, entregando su fruto, renunciando a toda tenencia" (Válery, Teoría poética y estética 89 ). Otros muchos poetas han relacionado su labor con la feminidad y la maternidad, con el vacío del útero y la procreación. Valgan, en este sentido, unas hermosas palabras del Rabí Najmán:

Revelar una nueva idea o un nuevo sendero en el servicio al Santo bendito sea es comparable a la preñez. Uno debe esperar permitiendo la "gestación" de la idea hasta que llegue el momento en el que esta pueda nacer.

Pero con la controversia, uno puede causar un "aborto", forzando a salir una idea aún no desarrollada, antes de su tiempo, destrozando entonces toda "la vida" que podría haber traído al mundo (Los cuentos del Rabi Najmán, 286).

El nacimiento humano se convierte, así, en metáfora de toda búsqueda de forma, de toda transformación del ayin en yesh. La feminidad se manifieste como una fuerza misteriosa que permite pasar de la nada a la existencia, rozando con ambos mundos, acogiendo el caos y moldeándolo en su seno. El Tsimtsum se alza, pues, como principio de toda creación: estética, física, y divina.

El discurso místico sobre la creación de la nada que aquí se ha presentado experimentó, según G. Scholem, todavía un giro posterior al que se debe hacer 
mención para concluir. Los kabalistas dieron a la doctrina de Aristóteles una peculiar interpretación ${ }^{68}$. Según Aristóteles, todas las cosas tienen materia, forma y no ser. Este último principio significa que una cosa no es todo lo que puede llegar a ser: nadie duda de que un trozo de madera pueda llegar a ser una mesa. Por lo tanto, en cada cosa, además de su materia y de la forma ya realizada en ella, existe una forma que aún no está realizada. Es lo que Aristóteles llama privación. Los kabalistas ${ }^{69}$ y Marcos Ricardo Barnatán han interpretado ese "no ser" como la nada inscrita en cada cosa y en cada poema, respectivamente. En cada algo hay inscrito también su abismo. Ningún ser, ningún poema es pleno, todos están quebrados e inconclusos por naturaleza. De esa relación incesante y siempre rejuvenecida con la Nada proviene la creación continuada y el siempre renovado milagro del inicio.

\subsubsection{Transcripciones lúdicas en lo manifestado}

El estímulo poético nace de la coincidencia entre un acontecimiento exterior y una circunstancia del corazón. La poesía de Marcos Ricardo Barnatán — como la de todo poeta - es original e inimitable, pero en sus procedimientos de expresión, y también en su material simbólico, tiene antecesores. Barnatán tiene una tendencia de escribir sobre el acto mismo de hacer poesía. En su voluntad de estilo, Barnatán estima primero la ausencia de forma; es decir, lo que nos entra del mundo y lo que le sale al poeta de la fragua interior debe aparecer tal cual viene, como materia, sin

\footnotetext{
${ }^{68}$ Según Harold Bloom, las obras kabalísticas constituyen los ejemplos clásicos de textos revisionistas. Esta es la razón por la cual Isaac Luria es un modelo de cómo un poeta revisa a sus antecesores: en este caso advertimos cómo Luria revisa la doctrina aristotélica y le da un nuevo giro. Luria recorre los diferentes escenarios que Bloom describe: como limitación (donde se examina el texto) y sustitución (donde se reemplaza el texto), para después llegar a la representación (donde se restaura el sentido).

${ }^{69}$ La disquisición mística de la doctrina de Aristóteles del "no ser" se halla expuesta con la máxima escrupulosidad en Puerta del que pregunta, de Azriel de Girona. Fue un miembro notable del círculo kabalístico de Gerona, además de ser discípulo de Isaac el Ciego.
} 
reducirse a fisonomía alguna. Y es así como explica la voz poética la génesis de su escritura en "El lugar del poema", perteneciente a Consulado general. El lector tiene que empezar cada verso abandonando el paso anterior e iniciando en él una nueva aventura rítmica:

No está el poema

Más allá de la palabra

Lo encierra el fuego del verbo

Late en el rayo violáceo que recibimos

Para ablandar la noche

Para entender la oscuridad del mundo.

En los arduos cristales del silencio

Brotó la rosa y nos dio la vida

El alto poder de poder nombrarla.

No está el poema

Más allá de la palabra

Se forja como el hierro y es ceniza

Aún caliente en el hueco de la tierra.

Está vivo en la letra que sangra

Estampado en nuestra memoria plural

$\mathrm{Y}$ el aire sabe arrastrarlo como un astro fugaz

Mostrando su bifronte cuerpo hecho

De gozo y de doliente despedida.

Somos los que se van.

Quizás solo somos agua y tiempo

Y lenguaje (Consulado general, 2001).

El espacio que comunica lo interno con lo externo se identifica con el

territorio vacío donde nace el poema. Es un lugar escurridizo, que se zambulle y solo a veces aflora a la superficie, con asombro, cual una epifanía. Su sentido es muy

amplio: recubre la existencia y la pasión, el ingenio y la evocación, la esperanza y la

muerte. Pero se trata, ante todo, de un espacio de verdad: allí donde confluyen la

reflexión y la sensibilidad, lo manifiesto y lo impalpable, el placer, los deleites, y

también sus límites.

Ricardo Barnatán juega, emplea elementos de la realidad: da nuevos valores a las palabras, las combina a través de su imaginación, pero su tarea no deja de hallarse 
en un lugar y en tiempos distintos. Él juega a crear, a concebir poemas ${ }^{70}$ y logra así una dimensión física, sensible. El recurso que emplea es la manipulación de la realidad palpable: a ella le imprime la huella del deseo y la fantasía. Sin embargo, la poesía de Barnatán es también objetivación, y nunca le falta un mínimo de esqueleto intelectual. Es un mensaje que quiere ser captado y comprendido para que, desde la comprensión del lector, puedan convivir el sentimiento y la original intuición. Para comprender y apreciar la poesía de Barnatán, no es buen camino entender intelectivamente primero las construcciones externas y, desde ello, después en el sentimiento, sino al revés: las construcciones externas no serán comprensibles sino cuando lleguemos a ellas desde el sentimiento que las provoca.

Sus poemas no son de una sola lectura: hay que entregarse primero al clima sentimental que es su alma poética, dejarse contagiar por la sugestión de las imágenes entrevistas, por las insistencias de los motivos y por el seguro poder de las construcciones sonoras, pues en la poesía de Marcos Ricardo Barnatán se escucha, como una voz confusa, un sentir denso más abajo del umbral de la conciencia.

Es interesante, en este punto, recordar la etimología de la palabra "poesía", procedente del griego poiesis. Aristóteles dividía las actividades humanas en tres categorías: theoria (conocimiento, búsqueda de la verdad), poiesis (realización, intento de crear algo) y praxis (acción, resolución práctica de los problemas). Poiesis hace referencia a la transformación de los pensamientos en materia. Poiesis deriva etimológicamente del antiguo término griego $\pi 01 \varepsilon ́ \omega$, que significa “crear”. Esta palabra - la raíz de nuestra moderna poesía - en un principio era un verbo, una

\footnotetext{
${ }^{70}$ Véase el concepto de la concepción de poemas de Bloom en La Cábala y la crítica: “el lector es, con respecto al poema, lo que es el poeta con respecto a su precursor. Todo lector es como un epígono, todo poema un heraldo y toda lectura un acto de "influencia", es decir, de ser influido por el poema y de influir en cualquier otro lector a quien comunicamos nuestra lectura” (96).
} 
acción que transforma y otorga continuidad al mundo. "Ni producción técnica ni creación en sentido romántico, el trabajo poético reconcilia al pensamiento con la materia y el tiempo, y a la persona con el mundo" (Man, La resistencia a la teoría 17).

Para Barnatán, la poesía habita allí donde los sueños y las fantasías abrazan el mundo sensible y se sirven de la realidad más inmediata para adquirir un cuerpo e ingresar en el tiempo compartido. El poeta hace, y de esa realización sin precedentes surge la creatividad. "La escritura es una pericia siempre creadora, y es una destreza en el ininterrumpido espacio-tiempo" (11). Su obstáculo o insuficiencia se debe a que siempre se desenvuelve en la frontera teórica entre lo subjetivo y lo que se advierte de manera objetiva.

Dicha incapacidad — ratifica Marcos Ricardo Barnatán— incita el que sea un espacio espinoso de definir y aparentemente inútil. "Un lugar y un tiempo que forman parte de la realidad; son momentos entregados a una misteriosa actividad en la que el sujeto empeña el alma, pero cuyo alcance solo él comprende" (Man, Alegorías a la lectura 94).

Y ese vivir creador se define como un hacer y como un estar en el mundo. El que juega o crea se halla en un lugar que participa del mundo, pero solo en su mente alcanza un sentido verdadero. Vive en una zona intermedia que los demás no ven. Encuentra, misteriosamente, lo familiar en lo irreconocible, y al igual que el niño que descubre gradualmente la realidad, lo hace suyo.

Barnatán es capaz de compartir una realidad aun desde la distancia espacial o temporal. En el poema "La casa del poeta destruida" se lleva a cabo una atractiva conexión entre dos poemas pertenecientes a diferentes periodos: la voz poética del 
poema de Marcos Ricardo Barnatán establece un diálogo con Alturas de Machu Picchu, de Pablo Neruda.

Una circunstancia interna angustiaba a Barnatán: una gran indignación por la muerte de Neruda. Marcos Ricardo acababa de leer, el 26 de septiembre del 1973, un artículo en Le Monde ${ }^{71}$ que describía el velatorio del poeta entre los restos de la que fue su casa en Santiago de Chile. Una vez más — plantea Barnatán— la barbarie había hecho estragos. Este amargo acontecimiento estimuló a Barnatán para que sus propios poemas se mezclaran con los de Pablo $\operatorname{Neruda}^{72}$, y su abatimiento provocó la intensa comunión entre poemas. "La casa del poeta destruida" hace pensar en un collage, en una creación mutua de Marcos Ricardo Barnatán con Alturas de Machu Picchu de Neruda. Se trata de una colaboración a través del tiempo y el espacio.

Del aire al aire como una red vacía En el ocaso sombrío del gigante Muerto en un solo abismo desolado.

Rota la casa por voraz tormenta El frío barre los escombros grises El intenso cadáver de ceniza y bruma.

En el silencio cómplice han ardido Los libros primordiales del poeta Ardió brutal la majestuosa tipografía.

Ardió hasta el fin su herencia deshonrada.

Al iniciar Alturas de Machu Picchu, Pablo Neruda lanza su red vacía, y centrado en el tema que conlleva años de historia, realizará la pesca milagrosa. "La voz poética logra levitar sobre la realidad de la cual parte, narrándole al lector así los pormenores de una experiencia impresionante (Schidlowsky, Pablo Neruda 13). Este

\footnotetext{
${ }^{71}$ Considerado un periódico de referencia por su alta calidad, la circulación promedio diaria es de 371.803 ejemplares.

${ }^{72}$ David Schidlowsky, Pablo Neruda y su tiempo.
} 
poema no es el primer intento de Pablo Neruda por descubrir dónde "vivía lo indestructible" lo imperecedero, la vida. Hay una confesión muy angustiada de lo que es su búsqueda:

Cuántas veces en las calles de invierno de una ciudad /o en un autobús o un barco en el crepúsculo, /o en la soledad más espesa, la de la noche de fiesta, /bajo el sonido de sombras y campanas, /en la misma gruta /del placer humano, /me quise detener a buscar la eterna veta /insondable que antes toqué en la piedra o /en el relámpago que el beso desprendía (Momentos cumbres de las literaturas hispánicas, 223).

Estamos ante la enigmática y vasta voz de la vida, la cual ha entrado en el cuerpo de un poeta que es todo luz. La primera pregunta que se puede plantear es si este poema puede ser una transcripción. La transcripción, pues, si así decidimos llamarla, nunca debe ser un intento de trasladar un texto de una lengua a otra ni de un autor a otro, con la vana ambición de conseguir una perfecta equivalencia, de encontrar una palabra que diga, que sustituya, a otra palabra. Tal como la entiende Marcos Ricardo, "este tipo de transcripción es una forma de apertura, un reto hacia delante, y nunca un intento de restituir el poema primero" (Bloom, El canon occidental 34).

Los críticos literarios Paul de Man y Harold Bloom confluyen en impugnar el mito del significado literario. Para De Man, detrás de la alucinación del significado contenido en el texto se agrieta un precipicio infranqueable. Para Bloom, en cambio, "lo importante de la literatura no es el significado de los textos sino lo que se concibe con ellos" (Bloom, La Cábala y la crítica 81). Para este crítico literario, hacer poesía, leer poesía, no debe significar responder a ninguna pregunta definitivamente y tampoco puede llevar a responder sobre el significado del poema en cuestión. Bloom cree, en cambio, que sí debe cambiar el entendimiento del poema, aunque ese cambio se deba a un propósito y a un periodo específico, como es el poema que acabamos de 
leer de Marcos Ricardo Barnatán. Lo que Bloom estipula en La ansiedad de las influencias es que "lo que se obtiene del poema no puede entenderse como una comprensión entre el sujeto y el objeto. A través del texto, el yo se pone en contacto con sí mismo" (92). Esta es la razón por la cual la literatura, para Bloom, sigue siendo una poderosa herramienta de la subjetividad de los sucesos extraordinarios.

La forma más obvia es la vivencia de este tipo de acontecimientos. Sin embargo, es una dimensión de la existencia entera que se puede experimentar en todas partes y en todo momento. Al utilizar el término misterio, Neruda no se refiere a ninguna calidad esotérica particular sino al misterio esencial del ser en cuanto al ser, a la naturaleza del ser como creación, a algo que está más allá del entendimiento humano.

El mundo es algo que aprehendemos pero no podemos comprender. Significativamente, el vocablo hebreo olam, que en tiempos posbíblicos pasó a denotar "mundo", deriva de la raíz alam, que significa "esconder" u "ocultar”. El mundo, como dice la voz poética de Alturas de Machu Picchu, es ocultamiento; su esencia es un misterio. Para Barnatán, la muerte del poeta chileno también es un misterio y por esa razón elige este poema de Neruda para hacer un collage y expresar su congoja y abatimiento por el tratamiento dado al gran poeta chileno que constantemente buscó aquello que nunca fue revelado.

Como se ha visto hasta aquí, la lectura plena y completa de un poema no existe. La voz poética de "La casa del poeta destruida" le responde al poema de Neruda y lo abre a un conjunto de posibilidades y valores nuevos. Ante el dolor, el poeta toma el texto, y no lo toma para interpretarlo sino para invocar y producir una 
comunicación dialógica donde se pueda desahogar el dolor. Como diría Bloom, lo importante no es el significado del texto sino lo que el lector hace de este ${ }^{73}$.

Días antes de la muerte de Pablo Neruda, el gobierno de Allende había sido degradado y destituido por el golpe de Estado comandado por el general Augusto Pinochet; el hogar de Neruda en Santiago había sido desvalijado y sus libros quemados. Sus honras fueron realizadas bajo la intimidación y el desafío de soldados armados con ametralladoras. En "La casa del poeta destruida", Barnatán pormenoriza todo el dolor que sintió ante la desaparición del poeta.

\subsubsection{El mal como parte de lo manifestado}

Es interesante destacar que, con excepción del primer capítulo del Libro del Génesis, el resto de la Torá no cesa en sus referencias al dolor y el mal en este mundo. Cuando los profetas miran el mundo, ven "zozobra y tinieblas, la lobreguez de la angustia" (Isaías 8:22). Así lo expresan algunos salmos citados a continuación.

Este es el motivo por el que no cesan de pedir ayuda: Hashem, Dios mío, en Ti me he refugiado; libérame de todos los que me persiguen y rescátame. Para que no destrocen como un león mi alma, despedazándome sin que haya quien me rescate. Hashem, Dios mío, ¿acaso hay iniquidad en mis manos? ¿Acaso le he retribuido con maldad a quien estuvo en paz conmigo?" (Salmos 7: 2-6). ¿Por qué, Hashem, estás alejado? ¿Acaso te ocultas en tiempos de sufrimientos? (Salmos 10: 43-45).

¿Hasta cuándo, Hashem, me olvidarás (como si lo hicieras) para siempre? ¿Hasta cuándo ocultarás Tu rostro de mí? ¿Hasta cuándo deberé buscar consejos para mi alma y habrá amargura en mi corazón todo el día? ¿Hasta cuándo prevalecerá mi enemigo sobre mí? Mírame, respóndeme Hashem, Dios mío; dale luz a mis ojos para que no duerma (el sueño de) la muerte (Salmos 13:24).

El salmista no concebía que este fuera un mundo feliz cuando versaba:

\footnotetext{
${ }^{73}$ Para más detalles sobre este concepto, véase a Harold Bloom: A Map of Misreading (Oxford: Oxford University Press, 1975).
} 
Protégeme como la pupila del ojo, a la sombra de Tus alas resguárdame de los malvados que me han desolado, de los enemigos de mi alma que me acorrala. Su grasa los ha recubierto, sus bocas hablan con arrogancia. Nuestros pies ahora quieren acorralar, su vista fijaron para merodear por la tierra. Su aspecto como el de un león que anhela destrozar y como el de un joven león al acecho en su escondite. Levántame, Hashem, enfréntalo, derrótalo, salva mi alma del malvado (Salmos 17: 8-14).

El ánimo del alma hebrea, a lo largo de todas las épocas, está manifiesto en el

Cantar de los Cantares:

El coro: ¿A dónde se fue tu amado, Oh, la más bella de las mujeres?

¿A dónde tu amado se volvió, para que contigo le busquemos?

La novia: Mi amado ha bajado a su huerto, a las eras balsameras, a apacentar en los huertos y recoger lirios.

Yo soy para mi amado y mi amado es para mí: Él pastorea entre los lirios (Can 6: 1-3).

El coro interviene para preparar la conclusión de los versos dos y tres, expresados por la novia. No hay que buscar al novio: sigue presentándose en el corazón de la novia, que es su huerto. La seguridad del amor mutuo se presenta en el último versículo.

Y ¿cómo es que nunca el Señor percibe pizca alguna de integridad en el hombre? Dios no pareció estar contento con el hombre en la tierra.

La tierra esta corrompida en la presencia de Dios: la tierra se llenó de violencia.

Dios miró a la tierra, y he aquí que estaba viciada, porque toda carne tenía una conducta viciosa.

Dijo, pues, Dios a Noé:

He decidido acabar con toda carne, porque la tierra está llena de violencia por culpa de ellos. Por eso, voy a exterminarlos $-\mathrm{a}$ los malvados-

(Gen. 6: 11-13).

Un gran lamento suena de un extremo al otro de la Torá: la crueldad del hombre es grande en la tierra. El mismo lamento que clama la voz poética de "La casa 
del poeta desaparecida" ante la maldad del hombre. Puede caracterizarse al hombre moderno como un ser endurecido ante las calamidades. Víctima de una devastación forzosa, su emotividad se reduce de modo creciente, su sentido de consternación disminuye. La diferencia entre el mal y el bien tiende a hacerse borrosa. Lo único que nos queda es sentirnos angustiados por la pérdida de nuestro sentido de atrocidad.

El tema que parece afectar más a Ricardo Barnatán es el hecho de que el mal progrese tan ventajosamente, y que este sea tan poderoso y seductor. Barnatán reflexiona en su poema "Ley" y plantea que el hombre tiene timbrada en la frente la infracción inicial y que esta conducta no ha sido subsanada aún por el propio hombre. Un tema antiguo se hace recurrente en el poemario El oráculo invocado de Ricardo Barnatán.

\section{Ley}

Si en la luminosa cuenca de la memoria reside aún vivo latente como una flor negativa el fantasma del pecado original. Si el olvido es una perfecta impostura, un sueño armado en el vacío único. Nunca podremos descargarnos de la culpa ni llegar al límite marcado: el fin del tiempo ${ }^{74}$. Y cómo no negarse, entonces, a declinar fugaz en las renegadas sombras esa peregrinación ancestral y perderla en la negra boca del exterminio. Si en la sangre intacta permanece germinada y ardiente la mística singularidad y el secreto destino grabado y fijo sigue en la frente.

La voz poética del poema "Ley” plantea que la iniquidad no es el problema último del hombre: la preocupación última del hombre es su vínculo con Dios. El mal penetró en la historia por la insubordinación del hombre a Dios, por quebrantar la

\footnotetext{
${ }^{74}$ Edmond Jabés es el autor de gran parte de la primera estrofa. Según el propio Barnatán, "Ley” es así una composición ambivalente: homenaje y respuesta, diálogo o contradicción.
} 
única mitsvá que tenía: no comer el fruto del árbol del conocimiento ${ }^{75}$. La respuesta bíblica al mal no es lo bueno sino lo santo. Es un intento de elevar al hombre a un nivel de existencia más alto, en el que el hombre no está solo cuando se enfrenta con el mal. El gozo de la mitsvá sobrepasa a la seducción del vicio.

La voz poética en la segunda estrofa plantea que no libramos la batalla "contra las renegadas sombras" (7) en nombre de un concepto abstracto del deber. No se hace el bien por razones de coexistencia porque este sea un valor, sino porque se lo debemos a Dios. Aunque consciente de los peligros y engaños de la existencia, la tradición judía es una advertencia perseverante de las monumentales e incesantes oportunidades de hacer el bien. Sin embargo, si el judaísmo hubiera confiado exclusivamente en las capacidades humanas para el bien, el mesianismo, entonces, pudiera implicar para muchos que cualquier conducta de vida, incluido el esfuerzo supremo del hombre, ha de fracasar en su intento de redimir el mundo. Es decir que, no obstante de toda su relevancia, la historia no se basta a sí misma. Barnatán expresa esta misma idea, pero de una forma mucho más poética, en la tercera parte del poema "Elegía":

Habrá en la brisa encendido un relámpago

Persiguiendo al recuerdo fugitivo, Violento sueño de amor en boca de ángel abrazándose inocente a la vida. ¿Por qué callar ahora, si adivinas la intensidad del huracán que viene a desnudar los cuerpos y lanzarlos hacia el secreto instante del placer? Se agitarán por ti, por nuestra exaltada lealtad, por aquellas tercas rosas que cubrían con inútil desvelo la indigencia. Habrá robusto sollozo en tu cabello,

\footnotetext{
${ }^{75}$ Abraham Joshua Heschel en Dios en busca del hombre plantea que el árbol del conocimiento tipifica al conocimiento entre el bien y el mal. La caída del hombre representa el enfrentamiento entre el mal y el bien, entre el deber y el querer. El árbol de la vida representa, por otra parte, la vida eterna.
} 
triste caricia rozándote las lágrimas y un desvestido aplauso revelado la serena ebriedad de la pureza. Se agitarán por ti, ¡abre las puertas, abre todas las ventanas de la casa! (9-27).

Barnatán platica con los textos, los interroga, les contesta, y no solamente lo hace con los textos seculares sino con los bíblicos, como se ha mostrado. La voz poética de "Ley" aborda un tema sólido dentro de la literatura: la libertad del hombre, y hace de este concepto un poema bello y único.

Según algunos místicos peninsulares —entre ellos Moisés de León—, el libre albedrío jamás se le acabará al hombre; en la Era mesiánica aun el hombre gozará de este privilegio concedido por Dios una vez, al principio de los tiempos. Sin embargo, los seres humanos tendrán todo el discernimiento — “la intensidad del huracán que viene/ a desnudar los cuerpos" (14-15) — para comportarse siguiendo el bien y seguir las enseñanzas de Dios. En la medida en que el individuo se aproxime a niveles encumbrados de sabiduría divina, "se agitarán por ti, / por nuestra exaltada lealtad" (17-18); se hará meritorio de la Providencia no limitada por las leyes naturales, y todo ocurrirá por el enorme Amor, la serena ebriedad de la pureza, que ostenta Dios por los hombres.

Solamente necesitamos separar nuestros corazones del mal, y así lo confirma la voz poética en sus dos últimas estrofas “Se agitarán por ti/ ¡Abre las puertas, / abre las ventanas de la casa!” (26-27).

Esencialmente los seres humanos son buenos ${ }^{76}$, nuestras almas son impolutas, su esencia es absolutamente pura y nuestras acciones no pueden afectar ni manchar en absoluto su pureza, pero en la práctica, una vez que el alma se inviste dentro de un

\footnotetext{
${ }^{76}$ Para Maimónides, el hombre es capaz de asumir su tarea y con ella su futuro, al contrario que los apocalípticos, que le niegan esa capacidad.
} 
cuerpo, luchando por conquistarlo, contra el alma animal y sus instintos, el resultado suma un individuo nauseabundo.

Redimiendo nuestras almas y saliendo de nuestro exilio personal transformamos el mundo y merecemos al Mesías. El ser humano es directamente responsable por su llegada [del Mesías], y definitivamente podemos lograrlo por más difícil que parezca. En “Ley”, Barnatán reitera su confianza en el compromiso divino:

Y cómo no negarse, entonces, a declinar fugaz en las renegadas sombras esa peregrinación ancestral y perderla en la negra boca del exterminio. Si en la sangre intacta permanece germinada y ardiente la mística singularidad y el secreto destino grabado y fijo sigue en la frente (7-12).

Según algunos comentarios del rabino Shea Rubinstein, el ser finito nunca puede alcanzar al infinito, a menos que lo descubra por medio del elemento divino que Dios nos obsequió, la neshamá (alma divina que es un pedazo de Dios), que nos permite traspasar a otra dimensión, trascendiendo las limitaciones humanas. Las mitzvot $t^{77}$ son Dios, expresión de Su voluntad, por eso ningún acto que emane de nuestra ocurrencia, por más motivador que sea y aunque sintamos que nos eleva de un modo sin igual, nos permitirá alcanzar a Dios. Solamente las mitzvot, que son la expresión de Su voluntad divina — Dios mismo a través de Dios — nos permitirán llegar a Dios, por lo que mitzvah es Unión.

Por otra parte, la tradición, según Scholem en Conceptos básicos del judaísmo: Dios, Creación, Revelación, Tradición y Salvación, atañe la realización de las mitzvot a la plenitud de la divina tarea marcada en la revelación, que exige “aplicación, explicación y decisión. Al mismo tiempo, es de hecho un verdadero crecimiento y se despliega desde dentro hacia afuera" (85).

\footnotetext{
${ }^{77}$ Mitzvá, vocablo hebreo que significa “mandamiento”. En plural, mitzvot.
} 


\subsection{UNA EXPERIENCIA BILATERAL: BENEFICIO Y ENRIQUECIMIENTO EN LOS DOS SENTIDOS}

Las nuevas formas de la poesía de Barnatán enriquecen tanto al autor como al lector. Ambos se benefician de reinterpretar las tradiciones ancestrales como experiencias no tan ajenas a lo moderno. Si la poesía nace en la antigüedad como expresión oral, hoy se puede concebir que aquella oralidad remota implique ya una dimensión multicultural. La poesía de Barnatán pretende provocar un diálogo generacional que cubra desde los tiempos bíblicos hasta nuestros días. Su tentativa más perentoria es la convivencia de la modernidad con la tradición, y de la alta cultura con la cultura popular, para de esta forma resaltar el valor ineludible del ser humano.

La importancia de innovar y de conectarse a la $\operatorname{tradición}^{78}$ se encuentra en los gérmenes de la Kábala, y estas dos tendencias — aparentemente paradójicas — laten con fuerza en poetas como Marcos Ricardo Barnatán. Las lecturas que lleva a cabo Barnatán son enormemente aventuradas, como también lo fueron las de Moisés de León —el autor del Zohar-, e incluso las de aquellos que perpetuaron el estudio de este.

La historia judía está caracterizada por poseer en sus arcas variadas interpretaciones de las Escrituras, pero no de una forma uniforme y similar; todo lo contrario: sus interpretaciones muestran una gran variedad. A este hecho es al que Bloom llama "teoría de la influencia" y Barnatán denomina "evolución poética".

El poema "Ley" se encuentra en la fisura entre el texto original francés, el que fue traducido al español, y los aportes y experiencias de Barnatán. Es un espacio de encuentro entre la perfección primera y la "belleza que acompaña”; un área vacía que

\footnotetext{
78 Según Scholem "la tradición y la intuición están aliadas y es esta la explicación de que la Kábala sea a la vez profundamente conservadora e intensamente revolucionaria”. Grandes tendencias de la mística judia, 204.
} 
se agrieta entre dos versos, entre dos mundos, y que el poeta intenta habitar con sus palabras.

Barnatán se aventura hasta el final en la versión del poema de Edmond Jabés. "La memoria y la mano" de Jabés le habla a Barnatán, y él argumenta y contesta con sus propias palabras, con su cuerpo, con la propia vida. No hay intención de mejorar ni de imponer. Se trata — como afirma el propio Barnatán— de un ofrecimiento: un acto de generosidad con los textos del pasado y los lectores del presente. Y para ello fue antes necesaria una labor de autodiscernimiento: dar con un camino desconocido e insólito que conduzca al corazón de uno mismo.

Se establece un diálogo que, como todo diálogo, actúa en dos direcciones. Los poemas traducidos no son entidades muertas que Marcos Ricardo Barnatán moldea a su gusto, sino cuerpos vivos, que cuestionan, rebaten y responden, a los que no se puede apresar ni en una interpretación ni en un significado. "Los poemas no han sido nunca para los poetas un discurso, cosificado y perfectamente inteligible y accesible, sino un discurso eterno, con el que se establece una relación mutua e intercambiable" (Bloom, La Cábala y la crítica 31), y permanece siempre en la lejanía.

Muchos de los poemas de El oráculo invocado son el resultado de una experiencia vivencial y de intercambio, ya sea con otro poema, con una pintura o con cualquier tipo de episodio tangible o subjetivo. "Lo que surge de esta conexión se expresa en un lugar intermedio. $\mathrm{Y}$ en esa cavidad que se abre entre el lector y lo que lee pueden acusarse hermosos frutos cuando esta lectura se realiza con todo el ser (Bloom, La ansiedad de las influencias 52). Se habla aquí de un encuentro, y todo encuentro verdadero transforma a las dos partes que participan en él. De ahí los poemas híbridos de Barnatán. Según el poeta, refiriéndose a la propia poesía: 
El oráculo no es un altavoz que entrega su discurso al paseante: el oráculo necesita que lo invoquen. Hay que preguntarle, y luego recibir sus enigmas, interpretarlos, hacerlos propios no sin un mínimo de esfuerzos. ¿Qué hace el poeta sino invocar constantemente el oráculo y recibir de él muchas veces el silencio, o una palabra, o una frase escasa, cuando no el torrente desbocado de una profecía? (prólogo de El oráculo invocado, 177).

Se ha producido, pues, ese ansiado encuentro entre la circunstancia exterior y la circunstancia del corazón. Una confluencia que vuelve todos los tiempos contemporáneos, y consigue que, al comprender lo ajeno, el hombre se conozca a sí mismo. El hombre jasídico se sitúa en esta misma línea de pensamiento: pone el acento en la interioridad como reflejo del mundo.

Según el Rabí Najmán, aquel que conduce su obstinación hacia Dios podrá ascender a una dimensión de genuina espiritualidad. Incluso si es obstaculizado o suspendido por fuerzas externas y se ve imposibilitado de cumplir su anhelo; ese hecho, no será empleado en su contra.

La principal retribución que espera al alma es obtener la Voluntad, que en el Zohar se llama Ra'ava d'Ra'avin, es decir, "Voluntad de Voluntades". El alma fue forzada a desprenderse desde los recintos más encumbrados para habitar aquí abajo, en este espacio material. Mientras el alma se halla encerrada en un cuerpo tangible y transitorio, el individuo debe aprender a adiestrar su voluntad hacia la Voluntad divina.

Se puede confrontar esta idea con la impresión de dos personas muy adheridas entre ellas. Cuanto más vasto sea el alejamiento que las separe, más grandioso será su empeño y atrevimiento de retornar a estar próximo. Con un perfil similar, el alma ha transitado de los mundos superiores, Kéter ${ }^{79}$, hacia este mundo.

\footnotetext{
${ }^{79}$ Según Knight, en Simbolismo cabalístico, el nombre de Dios en Kéter es Eheié, que ha sido comparado con el flujo hacia dentro y hacia afuera del aliento, simbolizando así el Kéter como la raíz
} 
Explica también el Rabí Natán ${ }^{80}$ que la recompensa — si es que se puede llamar así- o retribución para el que rastrea la espiritualidad es la disposición de avanzar espiritualmente con un perseverante acrecentamiento de la capacidad de distinguir entre el bien y el mal y, de esta manera, ser incluido en su Unidad.

La hermosura de la poesía de Barnatán y su cercanía con la mística hebrea radica en que se repliega al pasado perdido y también pronostica lo que con el tiempo se puede llegar a sentir, e incluso a ser.

Barnatán es de la opinión de que la poesía tiene "un perfil humanizador que el poeta puede despilfarrar y el atónito lector experimentar” (Borges, biografia total 67). El aire ético del Marcos Ricardo Barnatán es el de enaltecer por su perspectiva independiente, además de indómita, en la cual adentra al lector en una comprometida moral cimentada en la indagación y en la libertad como prueba de que la poesía es un ejercicio idóneo para cambiar el mundo.

Es por esa razón que la poesía de Barnatán busca establecer una zona en la que el sujeto individual, luego de aprender las lecciones de la posmodernidad, recapacite sobre su lugar en el mundo y rescate su capacidad de disquisición y quehacer.

La poesía de Barnatán exige a su hablante poético que desafíe el presente donde vive y lo fuerza a reflexionar, a buscar expectativas para que el individuo salga de esa falsa complacencia y desafortunada satisfacción.

Sus poemas definen al ser humano como aquel sujeto que reconoce la desilusión y la amargura pero que no quiere desistir, ya que anhela vivir de una forma diferente. El ofrecimiento del héroe poético es la solidaridad, pero no solo propuesta

de la que todo fluye y a la que todo retorna. El Aliento divino es un símbolo ampliamente usado entre los místicos orientales, y mucha de la enseñanza que hay detrás de Hatha Yoga está basada en él.

${ }^{80}$ Rabí Natán Sternhartz (1780-1844), conocido también como Rabí Natán de Breslev, fue discípulo del maestro Najmán de Breslev. 
sino vivida. La voz poética de muchos de sus poemas plantea el conflicto desde un punto de vista comprometido que hace entrar al lector en un diálogo indestructible con la realidad.

Para Barnatán, lo importante es dar respuesta al vacío con una energía obstinada de interpretación, pero siempre mostrándose conforme con la vaguedad o con las limitaciones de nuestro conocimiento. Todo viene por la necesidad que el sujeto individual tiene de encontrar sentido y coherencia en su vida, lo que — según Barnatán — resulta imposible sin la aceptación definitiva de Dios en la vida del hombre. Para alcanzar ese significado, es esencial la disposición o voluntad del sujeto que examina, recapitula, considera, compara, individualiza y descifra.

Los poemas de Barnatán vinculan presente, pasado y futuro. Marcos Ricardo entiende que el trabajo del poeta debe asumir todos los acontecimientos y viajar a través del tiempo actual, con todas las zozobras e incertidumbres, para instalar al lector en el mundo. Ese mismo universo que nos deja turbados, pero que no carece de riquezas para el hombre moderno, es el mismo mundo ${ }^{81}$ que Dios ha elegido para instaurar su morada.

Llegados a este punto se puede advertir que Barnatán suele convertir los espacios cotidianos en material de reflexión y acción, ya que ensambla el arranque de reflejos que facilita la poesía a las nuevas formas de vivir.

\footnotetext{
${ }^{81}$ Véase vol. II, p. 116b. Véase el punto de vista de Rabbenu Jananel, citado en Comentarios al Séfer Yesirá por R. Jehuda G. Barsilai aus Barcelona, ed. Halberstam, Berlín, 1885, p. 32.
} 


\subsection{LA KÁBALA REIVINDICADA POR LA POESÍA}

Según Harold Bloom —y todo parece indicar que Barnatán es de la misma opinión—, "cuando leemos con seriedad, elegimos y estas elecciones terminan por afectar, e incluso gobernar, nuestros deseos y nuestros actos" (Los vasos rotos 116). Bloom, incluso, llega a mencionar en Los vasos rotos que "si un poema que leo no se vuelve parte de mi futuro, entonces no debo leerlo más de una vez" (117-118).

Los místicos ${ }^{82}$, por otra parte — pero no con un perfil muy diferente-, plantean que, a través del estudio abundante y fecundo, el hombre puede cooperar con Dios en esa creación perenne con lo mejor de las competencias, vinculándose de esta forma el ser humano con el Kéter, la Voluntad (Madirolas, El camino 16).

El Kéter se define como el proyecto final de la Creación y la gratificación del Mundo venidero; sin embargo, el individuo advierte y vivencia su estímulo perpetuo aun en este mundo.

En el judaísmo, pensamiento y acto están fundidos en uno. “Cuando un individuo siente y piensa penetra en todo lo que hace, y cuando hace está involucrado en todo lo que siente y piensa" (Pinjas, Comentarios 44). Los anhelos espirituales están condenados a la ruina cuado se intenta cultivar los actos a expensas de los pensamientos o los pensamientos a expensas de los actos. ¿De dónde nace el poema: de la visión interior del artista o de su lucha con las palabras? El vivir es como una obra de arte, producto de una visión y de una lucha de situaciones concretas. "Al representar lo sagrado en el escenario del vivir concreto se percibe la conexión del

\footnotetext{
${ }^{82}$ Se ha aplicado a la vida del individuo el principio de que las bendiciones de lo alto solo descienden cuando hay alguna sustancia, y no mera vacuidad. El versículo "Yo soy de mi amado y su deseo es hacia mí" (Cantar de los Cantares, 7:11) es interpretado como referido a la relación entre Dios y el hombre. Primero debo pertenecerle a Él y luego su deseo es hacía mí; primero prepararé un sitio para Dios y luego su deseo es hacia mí. "Si el hombre se empeña en purificarse a él mismo, entonces la Shejiná se posa sobre él” Zohar, vol I, p.88 a-b.
} 
hombre con lo divino, se siente la presencia de lo divino. Lo indescifrable en la reflexión se intuye en los hechos" (Heschel, Dios en busca del hombre 15).

Es cautivador percibir que el Rabí Najmán ${ }^{83}$ ilustra que mediante la acción de alimentarse es factible adquirir la elevada conciencia de este anhelo. La Voluntad es Kéter, una categoría espiritual muy sublime: la más elevada, mientras que comer puede ser considerada una competencia profana. Sin embargo — aclara Rabí Natán—, la acción de comer posibilita la conquista de la meta del hombre a este nivel. El comer soporta la vida; conservando el alma adherida al cuerpo.

Esto sucede básicamente al comer con el propósito de alcanzar las energías imprescindibles para la obtención de la espiritualidad, pues esta forma de comer iza las porciones de santidad o perfección que se hallan en la comida. Comer con esta disposición puede conducir al individuo a una profunda avidez por lo espiritual, al punto en que pueda aunarse al Kéter. En su poema, "Tabla de las diez sefirot", Barnatán lo explica de la siguiente manera:

1. La corona reside en la cabeza Es poder moderador y original Kéter

2. La Sabiduría reside en la cabeza Es poder equilibrado e inmutable.

3. La inteligencia se acerca al corazón.

Hohkma Es poder equilibrado y activo.

4. El Amor se acerca a la derecha Es poder grandioso y universal.

5. La Fuerza reside en el hombre Es poder grandioso y concentrado.

6. La Belleza reside en el centro Es poderoso corazón del cielo.

7. El Triunfo se acerca a la derecha Es poder luminoso y eterno.

Bina

Guedula

Hessed

Guevura

Din

Tiferet

Nessah

8. El Esplendor se acerca a la izquierda Es poder del espíritu y de la vida.

Hod

9. La Fundación reside en la base Es poder absoluto y generador.
Yesod

\footnotetext{
${ }^{83}$ Véase para más información Leyes seleccionadas, donde aclara leyes y costumbres judías desde su propio punto de vista.
} 
10. El Reino reside en los pies

Es el Poder, Gran Obra de Dios. Malkut

Es interesante notar que la Kábala, tradicionalmente considerada una

disciplina mística, también se ocupa de ámbitos muy cercanos a la filosofía o a la

psicología. Las preguntas que se plantean, referentes a la correspondencia del hombre

con el Universo, los vínculos entre la existencia y el sueño, la imaginación y la

vivencia, conducen a distintos tipos de argumentos: lógicos, alegóricos, deductivos y

mágicos, lo que hace de la Kábala una corriente de pensamiento de muy dificultosa

clasificación.

La comunicación entre el mundo divino y el humano, sus contradicciones y

destellos, constituye una de sus cúspides. Todo contacto se sitúa, como el poema, en

un espacio abierto e inasible. Las semejanzas entre Dios y el hombre son

escenificadas, no sin sorpresa, en el ámbito del juego. Moshe Idel explica, a propósito

de Abraham Abulafia:

Se puede imitar a Dios explotando el poder creativo del lenguaje. La mímesis se logra gracias a una práctica combinatoria que no copia ningún modelo ni mensaje preexistente. Subyace la idea de que Dios y el hombre agotan todo el material inherente a las unidades lingüísticas, conceden realidad a los elementos no semánticos de todas las posibles combinaciones de letras en el alefato hebreo. Es, sobre todo, la seriedad del hombre que juega, la que es capaz de imitar a Dios. Así, en las interpretaciones medievales de la técnica combinatoria del Séfer Yetsirá, a veces se recurre a la imagen de Dios jugando (Lenguaje, Torá y hermenéutica en Abraham Abulafia 135).

El juego no es una actividad superficial ni arbitraria: está cargado de sentido.

Para acercarse a la Divinidad, el hombre debe emplear la seriedad del que juega, por muy paradójica que parezca esta expresión. El niño se manifiesta muy respetuoso y severo en sus juegos, si entendemos la solemnidad en términos de compromiso. No se trata, para él, de un proyecto banal, sino del establecimiento, dentro de la realidad, de 
otro espacio con sus propios códigos, normas, preceptos, personajes y sucesiones: un mundo ante el cual se despilfarran atenciones y cuidados.

El juego, como ya se ha dicho, incorpora al universo de las fantasías, le confiere una existencia más allá de la interioridad. ¿Y algún acto implica tanta responsabilidad como el de conceder a un cuerpo un lugar y un acto? El niño manifiesta una máxima preocupación por sus juguetes: no son lo que pensamos, quiere decirnos; en su mundo, nada es lo que parece. Los juguetes constituyen un tesoro misterioso.

Quizá no sea de asombrar que algunas veces se presente al Creador jugando. Las letras, un material en principio insustancial, alcanzan un valor insospechado, de difícil comprensión para el ser humano, en las manos de la Divinidad que juega. Dios forma sus rasgos, les da cuerpo, descubre en ellas caudales ocultos: una realidad que va más allá de su uso instrumental para la formación de palabras. El hombre se queda desconcertado, absorto, extasiado ante ese fenómeno que no acaba. Se encuentra en un mundo cuyas reglas no comprende. Y en su exploración de lo sensible, trata de imitar al Creador mediante el juego. Enuncia normas nuevas, indaga diferentes ritos, abre, con su imaginación, otros senderos con la mayor seriedad y el máximo placer. Surgen así mundos paralelos plagados de criaturas monstruosas o invisibles, de promesas siempre por cumplir. En su poema "La casa de Dios”, Barnatán lo manifiesta así:

Dos bueyes simétricos

Que los cuatro tríos miran hacia cuatro destinos Y leones y querubines y sacrificados carneros entre diez bazas y conchas menores, molduras suaves y ensombrecidos bajo relieve de brumas, entre el destello cristalino de los divinos metales, en el centro mismo del Santuario, el Arca y el Tabernáculo fueron depositados, nunca nunca desampararé al pueblo mío (42-50). 
El ser humano, en su intento por descubrir las diferentes configuraciones de lo real, se mueve siempre en un territorio de probabilidades e imprevistos. Ante las palabras, crece la sospecha de que quizá expresen más de lo que dicen: como ecos de una voz que se desliza y que nunca llega a diferenciarse con claridad. El kabalista, sumergido en su faena combinatoria, en su mundo hecho de letras, parece preguntarse: ¿no será el Universo, en el fondo, un juego de Dios? ¿No nos subyugará el Creador a insólitos designios que no comprendemos simplemente porque está jugando y nosotros no vemos el conjunto del tablero ni podemos comprender la eternidad? La escritura se descubre, entonces, como una aglomeración llena de escondites: allí donde las palabras juegan a ser otras, a vincularse con lo que no dicen, a esconderse detrás de lo que callan (Idel, Cábala: nuevas perspectivas 40).

El juego y el lenguaje mantienen una estrecha amistad. Ellos son, pues, el rostro y el dorso de una misma tarea, consistente en rivalizar lo real a través la ficción. El lenguaje se correlaciona al dictamen del juego, es un práctica de reglas deficientes o incompletas de sentido, pero imperiosas. La voz poética de Dictado por los antiguos sabios de Marcos Ricardo plantea: “Un lenguaje puede ser un juego maléfico. El encantamiento, un recurso válido para acceder a la suprema armonía” (1-2).

La actitud lúdica ocasiona al lenguaje el inconveniente de lo fijado o de lo limitado. Ambos — tanto la práctica del juego como la lengua — jamás negarán su nacimiento común, aunque después se independizarán. La lengua de los poetas, según Barnatán en La Kábala: una mística del lenguaje, se convirtió en el reverso del lenguaje investigador científico y el juego se contrapuso a la ocupación circunspecta. La poesía retorna a la ingenuidad, al candor y a la simpleza, al intentar que las palabras deambulen y retocen con la sintaxis. El cometido impuesto al lenguaje por el 
acoplamiento sintáctico experimental nutre el quehacer lúdico de los artistas y creadores. Es por lo que lenguaje es el prototipo hermenéutico ${ }^{84}$ del Cosmos. Como se puede advertir, lo lúdico y lo lingüístico tienen mucho en común.

Algunas veces durante un diálogo gozamos de una forma parecida a la que experimentamos durante un juego, por lo que el lenguaje es un juguete. Es convencional, ya que es común a todos los individuos, y tiene a su vez un componente subjetivo ya que cada persona lo entiende de una forma muy peculiar, propia y personal.

Ambos, el juego y el lenguaje, experimentan una relación gozosa en la que se intenta una justificación total y, al mismo tiempo, una separación parcial. ¿Qué es lo que hacen los poemas con las palabras? Ellos juegan a cambiar la sintaxis o a cambiar un término por otro. Ella - la poesía - obsequia al juego la conveniencia de conservarse y perpetuarse, pero a su vez, el juego se enfrenta a esa incapacidad o ineptitud de la lengua: su incomunicación. Y justo es el juego el que le añade esa energía necesaria para levantar un orden humano nuevo en el cual domine la libertad.

El requisito del lenguaje es la renovación de la libertad quebrantada en el Universo. Es así como entendemos por qué Julio Cortázar delimitó la poesía como juego:

Digo juego con la gravedad con que lo dicen los niños. Toda poesía que merezca ese nombre es un juego, y solo una tradición romántica ya inoperante persistirá en atribuir a una inspiración mal definible y a un privilegio mesiánico del poeta, productos en los que las técnicas y las fatalidades de la mentalidad mágica y lúdica se aplican naturalmente (como lo hace el niño cuando juega) a una ruptura del condicionamiento corriente, a una asimilación o reconquista o descubrimiento de todo lo que está al otro lado de la Gran Costumbre. El poeta no es menos "importante" visto a la luz de su verdadera

\footnotetext{
${ }^{84}$ Véase para más información Verdad y método, de Hans Georg Gadamer. Según este crítico, "la poesía, como herramienta para traer la verdad, para desocultar, posee un innegable valor, ya que crea mundos y fabrica lenguajes" (51).
} 
actividad [...] porque jugar poesía es jugar a pleno, echar hasta el último centavo sobre el tapete para arruinarse o hacer saltar la banca. Nada más riguroso que un juego; los niños respetan las leyes del barrilete o las esquinitas con un ahínco que no ponen en las de la gramática (Último round, pp. 65-66).

"El discurso poético acumula la revelación de la esencia inherente misma del hombre. Y es la poesía la que funda una angosta conexión entre el hombre y su forma de expresión: el lenguaje" (Gadamer, Poema y diálogo 63).

Esta es la razón por la que la Kábala era determinada por los místicos como la poesía de la Torá, debido a su carácter creativo, renovador, ingenioso y poético. El crítico norteamericano Gil Anidjar, investigador de la poética sefardita y de la cosmología judía, plantea que la tradición kabalística, a diferencia de otras tradiciones místicas, se ha cimentado al margen de la tradición literaria. Según este crítico, textos como el Zohar no han sido confrontados con la literatura de su época, bien sea esta judía o no judía, ni se han indagado sus huellas en las obras posteriores.

Según él, no ha producido la merecida curiosidad el hecho de que una cantidad respetable de kabalistas fueran también poetas. La Kábala — afirma Anidjar— no solamente es literatura, sino también es literatura. En La cábala, la literatura y lo sefardita, el profesor de la Universidad de Columbia se atreve a plantear que "ya no se debería poder imaginar ni leer la Kábala sin reconocer su alcance literario, tanto en términos intrínsecos como comparativos, y también en términos de efectos textuales, culturales, religiosos, seculares o históricos" (18).

Si se recuerda que el lenguaje es donde habita el Ser y es el lugar de la verdad, es comprensible, entonces, esta situación. "El poeta y el lector moderno ya entienden que también la poesía es la excelsitud del lenguaje" (Knight, Simbolismo cabalístico 34). Para el kabalista, la Torá es la santidad en palabras. Tal y como "es imposible concebir a Dios sin el mundo, también es imposible concebir Su preocupación sin la 
Torá. Si Dios está vivo, la Torá es Su voz. No hay otra obra tan merecedora de ser considerada una manifestación de Su voluntad" (Heschel, Dios en busca del hombre 76). Si la creencia en la inmanencia de Dios en la naturaleza es plausible, la creencia en la inmanencia de Dios es la Torá es imperativa. La Torá no se ocupa de la divinidad sino de la humanidad.

Esta es la razón por la cual la Kábala y el Zohar pueden reivindicarse desde la literatura, porque ambas "apelan a una lectura de figuras retóricas e históricas, a una sinestesia del ver y del leer, a la difícil unión de la lectura y la figura, de los signos de la historia y su poder afectivo" ${ }^{\text {85 }}$. Vocablo e imagen, memoria y emoción, iluminación y tenacidad se dan la mano en unos textos que, por su carácter esotérico, ofrecen iconografías y tropologías que cautivan a la fantasía artística.

\subsection{EL LENGUAJE PRÁTICO CUANDO DE LO INEFABLE TRATA}

Hay una observación que hace la voz poética en muchos de los poemas de Barnatán compilados en El oráculo invocado, y es la del desconocimiento de la dimensión ${ }^{86}$ inefable del ser humano. Por inefable no se entiende lo desconocido como tal. Las cosas hoy desconocidas pueden ser conocidas dentro de mil años. Por inefable se entiende, en el poema, a aquel aspecto de la realidad que por su naturaleza misma está más allá de nuestra comprensión y respecto del cual la mente reconoce que escapa a sus propios alcances. Tampoco se refiere lo inefable a un reino separado

${ }^{85}$ La cábala y la literatura y lo sefardita, p. 16 Anidjar, Gil.

\footnotetext{
${ }^{86}$ Marcos Ricardo Barnatán se interesa por la etapa más antigua de las enseñanzas místicas del judaísmo, que ofrecen tres aspectos. El primero, que le llama la atención, es que las enseñanzas giran alrededor de la cuestión de la Mercabá - esto es, de las manifestaciones de Dios, sus atributos y su relación con el mundo- , por una parte, y en torno a la creación, por la otra. La segunda perspectiva, que lo cautivó, es la hipostatización de la Torá que hace de ella, con sus letras, un ser eterno, o por lo menos el más antiguo de todos, y a la vez un instrumento en la creación del mundo. Ya el tercer aspecto se relaciona con los nombres de Dios y de los ángeles.
} 
de lo perceptible y lo conocido. Se refiere a la correlación de lo conocido y lo desconocido, de lo cognoscible y lo incognoscible con lo que la mente se topa en todos sus actos de pensamiento y sentimiento.

La voz poética es capaz de hablar de guerras, de inquisiciones, de luchas internas, de justos y necios, de desgracias y de fortunas, pero no sabe quién es el hombre que lleva dentro. Lo inefable en los poemas del escritor que nos ocupa se refiere a lo trascendente, que no es sinónimo de ausencia de significado sino de que su significado está oculto. La esencia de la realidad sigue siendo incompatible con nuestras categorías, Barnatán deduce y manifiesta a través de sus poemas que la naturaleza, el ser en cuanto ser, y hasta el acto mismo de pensar, escapan a los alcances de la aprehensión. La esencia de las cosas es inefable, y por lo tanto, incompatible con la mente humana. Esta incompatibilidad es la fuente de todo pensar creativo en el arte, la religión y la vida moral.

Se puede sugerir que, tal como el descubrimiento de la compatibilidad de la realidad y la mente humana es la raíz de la ciencia, así también el descubrimiento de la incompatibilidad del mundo y la mente humana es la raíz de la intuición artística y religiosa. En el reino de lo inefable, donde el misterio se halla al alcance de todos los pensamientos, nacen los problemas últimos de la religión, y también de la literatura.

La obra poética de Marcos R. Barnatán, en última instancia, nos dice que en verdad el vacío muerto del alma es intolerable para el hombre. No se puede sobrevivir a menos que se sepa qué se nos pide, para así entender quién es el hombre y cuál es su misión. ¿Pero a quién le debe algo el hombre en su invalorable e irrefrenada libertad? Llegados a este punto se puede concluir que el estímulo poético en Marcos Ricardo Barnatán brota de esa relación entre el accidente extrínseco y la circunstancia del espíritu. Barnatán se aventura hasta el final en la traducción de los textos que le 
hablan por su visión exiliar (Tsimsum) y a los que él responde con sus propias representaciones con su cuerpo, con toda su vida. No hay en él voluntad de imponer.

Se trata aquí, como plantea Barnatán, de un acto de generosidad con los textos del pasado y los lectores del presente. Los poemas traducidos no son entidades muertas que Barnatán moldea a su gusto, sino cuerpos vivos que responden e interrogan a los que no se pueden apresar ni en una interpretación ni en un significado. Los poemas ${ }^{87}$ de El oráculo invocado son el resultado de tal experiencia y se sitúan por ello en un lugar intermedio, en el vacío que se abre entre lector y lo que lee cuando esta lectura se realiza con todo el ser. Esta es la razón por la cual después de leer a Barnatán se puede renunciar a viajar más lejos, pero ya no se puede ignorar que el viaje es posible.

Hablamos aquí de un encuentro, y todo encuentro verdadero transforma a las dos partes que participan en él. La confluencia en los poemas de Marcos Ricardo Barnatán — los incluidos en el poemario El oráculo invocado — vuelve todos los tiempos contemporáneos y consigue que, al comprender lo extraño, el hombre se conozca a sí mismo. Como se ha demostrado hasta aquí, el misticismo hebreo se sitúa en esa misma línea de pensamiento: pone el acento en la interioridad como reflejo del mundo.

Leer los poemas de Marcos R. Barnatán como literatura afín a los textos místicos hebreos es posible porque ellos son capaces de expresar mucho más de lo que se proponen: su polivalencia reside en ese desajuste que habita en el propio lenguaje. La voz poética, en muchos de los poemas de Barnatán, expresa argumentos

\footnotetext{
${ }^{87}$ La voz discursiva de los poemas o de la obra narrativa de Barnatán ostenta una poderosa sabiduría que hace que ambos conformen una pieza dentro del sistema cultural al que remiten. El lector debe partir de un juego de complicidades y presupuestos y el autor busca sus fuentes en la mística judía. Para Barnatán la escritura es un ingrediente de la vida, y no la concibe ni como salvación ni como catarsis; tampoco observa en ella una razón para ser vital.
} 
provenientes de un pasado remoto; como una vez ya ha sugerido Harold Bloom. Y es al lector a quien le toca descubrir y sacarlo a la luz.

Se puede concluir que leer la Kábala como literatura es mostrarse de acuerdo con la agudeza de un lenguaje cuya pujanza imaginativa y retórica se ocupa de los textos. Leer la Kábala como literatura es rememorar una fuerza y una autoridad expresiva. Por otra parte, la fe es el reverso del acto artístico, ya que esta última intenta apresar lo intangible en lo tangible. En la fe no se intenta descifrar, sino que el hombre se eleva sobre su propio discernimiento para intentar vivir en armonía con lo que es pertinente a Dios. 
La tradición y la intuición están aliadas y es esta la explicación de que la Kábala sea a la vez profundamente conservadora e intensamente revolucionaria. Gershom Scholem

\section{MULTICULTURALIDAD NARRATIVA EN EL LABERINTO DE SION}

Después de la primera mitad del siglo XX, la narrativa se centra en aprovechar las búsquedas o las exploraciones hechas antes e intenta combinarlas de manera original. "La narrativa posmoderna está centrada en la crisis del yo y en la crisis del conocimiento" (Lyon, Postmodernidad 96), lo cual inspira que muchos personajes posmodernos indaguen — aunque sin mucha fe- e intenten encontrar explicaciones referidas a la vida y al mundo.

En El laberinto de Sión, Marcos Ricardo Barnatán ejemplifica una serie de tendencias dominantes en el posmodernismo, como el restablecimiento de la marginalidad, el empleo de estéticas que permiten un espacio a la discrepancia o a la divergencia, el concepto de la literatura "como una experiencia colectiva abierta a la colaboración del lector, y también la reescritura paródica de las tradiciones literarias y religiosas" (Anderson, Los orígenes de la posmodernidad 23), con el propósito de desmitificar algunos de los perfiles característicos del estilo narrativo canónico religioso.

El laberinto de Sión responde a dos pasiones bifurcadas: una se hace patente en su aparente impulso narrativo, y la otra es la que lleva al lector a indagar el contexto en el que se inscribe. En el presente capítulo se estudiará el contexto teórico en el que surge la primera novela de Marcos Ricardo Barnatán, sólidamente ligada con el posmodernismo. 
Barnatán rechaza las grandes verdades, las concepciones unívocas de los modelos herméticos, además de los fundamentos coherentes de la historia. Al final de este trabajo quedará demostrado que este escritor anhela la infinitud y la tolerancia. Él hace encarnar un nuevo periodo en el desarrollo del individuo, donde impera una mayor autonomía para la actividad humana, ya que no se encontrará subyugado por paradigmas. Con esta autonomía, el hombre alcanzará — según Barnatán — un nuevo valor aislado de las monoidentidades nacionales. Laberinto, como quedará demostrado, reivindica lo múltiple y lo fragmentado frente a lo unívoco. Esta es la razón por la cual los elementos totalizantes y los fragmentarios cohabitan en tensión dentro de la novela que nos ocupa.

\subsection{El LABERINTO DE SIÓN A LA LUZ DE LA TEORÍA LITERARIA}

El término posmodernidad alude a una gran variedad de movimientos culturales, literarios y filosóficos, y todos ellos perpetuados en el siglo XX. Un problema que se presenta cuando nos referimos a este tema aparece justamente cuando deseamos definirlo con precisión. El problema de esta tarea está relacionado con diversos factores, entre los cuales se encuentra la falta de un marco teórico válido para hacer posible una tarea de análisis de todos los acontecimientos que se van dando a lo largo de este complejo proceso que se llama posmodernismo. Pero en nuestra opinión, es eso precisamente lo que falta en el posmodernismo: una unidad, una totalidad, un orden.

El término posmodernismo, a pesar de haberse impuesto en el mundo académico, no ha dejado de generar polémicas debido a que existen diversas y variadas ideologías en la mente de cada analista, además de múltiples y complejas perspectivas críticas. Muchos consideran el posmodernismo como una expresión 
cultural (Jameson), y otros son de la opinión de que es un estilo que puede incluso existir independientemente del momento histórico determinado (Gaggi, El postmodernismo moderno 37). Parece, entonces, interesante estudiar en líneas generales lo que plantean algunos de los teóricos más prominentes dentro del mundo académico, para así poder adentrarnos aun más en la narrativa de Marcos Ricardo Barnatán. Tres de los analistas literarios a los que se hará referencia son Ihab Hassan, Brian McHale y Vattimo.

Según el profesor Navarro "uno de los primeros críticos en definir el concepto del posmodernismo desde la perspectiva literaria fue Ihab Hassan” (Navarro, Postmodernismo 18). Este crítico señala una heterogeneidad enorme de paradigmas y escuelas dentro del posmodernismo; sin embargo — plantea Hassan—, existe una serie de tendencias culturales, una variedad de procedimientos y una diversidad de actitudes que pueden ser agrupadas bajo la inscripción de posmodernismo.

El aspecto general que Hassan, en su ensayo The Dismemberment of Orpheus, observa en los representantes del postmodernismo y las vanguardias es el furor de la “voluntad de deshacer". A esta característica, Hassan agrega la tendencia de recuperar la cultura popular. En general, se puede plantear que el posmodernismo rechaza el establecimiento del elitismo de las vanguardias y el cultismo modernista.

Hassan explica, en la misma, algunos de los problemas conceptuales que conlleva toda periodización y ofrece un esquema con las diferencias que distancian el posmodernismo del modernismo, pero no tiene caso profundizar en ese asunto aquí.

Además, postula que el posmodernismo "se encuentra constituido por dos elementos teóricos básicos" (Navarro, La metaficción 4): la indeterminación y la inmanencia. Dos conceptos que el profesor Juan Navarro explica profusamente en su ensayo Postmodernismo y metaficción historiográfica: una perspectiva 
interamericana. La indeterminación a la que se refiere Hassan responde a la voluntad de deshacer que caracteriza al discurso posmodernista. En la literatura, esta preferencia se manifiesta en un cuestionamiento de los conceptos canonizados por el mundo académico.

Por otro lado, la inmanencia viene definida por la capacidad de la mente para generalizarse mediante símbolos, intervenir en la vida y actuar sobre ella. Finalmente, Hassan concluye el ensayo señalando las paradojas que encierra el posmodernismo. A pesar de que esta corriente prefiere lo provisorio, lo lúdico y lo contradictorio, se inclina por las interacciones generalizadas, por los medios de comunicación y por los lenguajes.

Según Hassan, la humanidad está pasando por una etapa de globalización que, sin embargo, se desmiembra en comunidades, asociaciones y grupos de todo tipo. La crítica de Hassan, según Juan Navarro, peca por considerar el posmodernismo como "una especie de utopía libertaria gobernada por el poder ilimitado de la imaginación" (20).

Por otra parte, el mismo profesor plantea que el teórico Brian McHale centra su análisis en la llamada narrativa posmodernista. Bajo esa fórmula, este teórico discute los más variados movimientos literarios, a diferencia de otros estudiosos del posmodernismo que se preocupan por disciplinas como el cine, la arquitectura o las culturas de masas.

Según McHale, el posmodernismo se caracteriza por las preocupaciones de carácter ontológico. Los posmodernistas "se muestran más interesados en reflexionar sobre la naturaleza de lo literario y su relación con la realidad" (Navarro, La metaficción 6) y vienen a establecer la pregunta: ¿cuál es la relación que puede llegar a establecer un texto con el mundo? ¿Estamos intelectualmente justificados al inferir 
de nuestra percepción una realidad que se encuentra más allá de ella? Barnatán parece encontrar la respuesta a esta pregunta en la mística judía.

Al percibir la dimensión espiritual de todo ser, es posible percatarnos de la absoluta realidad de lo divino. Al formular un credo, al afirmar "Dios es", se crea una limitación al hacer descender una realidad imperiosa hasta el nivel del pensamiento. El pensamiento no es sino una secuela de nuestra creencia" (Heschel, Dios en busca del hombre 71).

En otras palabras, la fe en la realidad de Dios no configura una situación en la que primero poseemos una idea y luego postulamos la equivalencia óptica de esa idea, o - para usar una comparación kantiana - una situación en la que primero poseemos la idea de cien dólares y luego, sobre la base de esa idea, afirmamos poseerlos. Lo que aquí se da es la real posesión de los dólares y luego el intento de contar la suma. Cabe la posibilidad de error al contar los billetes, pero la existencia de los billetes mismos es una realidad concreta.

Dicho de otro modo, la creencia en Su realidad no es un salto sobre el eslabón faltante de un silogismo sino una recuperación: "no se incorpora un nuevo modo de ver sino que se abandona uno, trasciende el egocentrismo y nos cuestionamos el yo, así como todas las pretensiones cognoscitivas" (Gadamer, Poema y diálogo 72). Esta creencia es un supuesto ontológico.

Según Barnatán, en lo profundo del pensar humano se presupone alguna realidad última que, en el nivel del pensamiento discursivo, se cristaliza en el concepto de un poder, un principio o una estructura. Este es el orden en el pensar y existir: en primer término razonar acerca de Él. La especulación metafísica invirtió el orden: el razonamiento ocupa el primer lugar, y la pregunta acerca de Su realidad, el 
segundo. "Para la metafísica, la existencia de Dios se demuestra, o no es real" (Heschel, Dios en busca del hombre 109).

Barnatán es de la opinión de que, tal como no hay pensamiento acerca del mundo sin la premisa de la realidad del mundo, tampoco puede haber pensamiento acerca de Dios sin la premisa de la realidad de Dios.

Existe una disparidad profunda entre el hombre y la realidad, entre la experiencia y la expresión, entre la percepción y la concepción, entre la mente y el misterio. "Esa es la razón por la que para poder expresar algo, manifestar ideas, debemos transigir y hacer concesiones, ya que las ideas últimas nunca pueden expresarse” (Barnatán, La Kábala 17). Es por esta razón que Barnatán encuentra en el misticismo un terreno fértil y en sintonía para su estética. Este escritor está muy interesado por temas ontológicos, lo que, como plantea el crítico McHale, es una postura muy natural dentro del posmodernismo.

En su ensayo, McHale menciona una lista de características de los textos posmodernos y señala algunas de los métodos más recurrentes. Según este teórico, el posmodernismo presenta “modelos para armar", con lo cual parece que todos estamos de acuerdo.

Sin embargo, con lo que el profesor Juan Navarro no parece estar de acuerdo es con que McHale atribuya preocupaciones ontológicas a escritores como Fuentes y Cortázar; sus obras muestran un creciente interés por cuestiones de orden epistemológico. Obviamente, McHale no apoyó su teórica en obras posmodernistas como El laberinto de Sión de Marcos Ricardo Barnatán. Si hubiese sido así, el postulado de McHale de que los escritores posmodernistas se preocupan mucho más por postulados ontológicos que por epistemológicos hubiese quedado mucho mejor representado. 
Por último, y para finalizar este enmarcamiento teórico, mencionaremos ligeramente al filósofo italiano Vattimo, uno de los principales autores del postmodernismo y considerado el filósofo del pensiero debole, el "pensamiento débil”".

El posmodernismo propone la hibridación, la desconcentración de la jurisdicción intelectual y el desengaño ante los grandes relatos. Vattimo intenta especificar la tendencia posmoderna con transparencia. Para este crítico lo sustancial no son los sucesos sino sus interpretaciones, lo que entronca muy bien con la estética de Barnatán y, a su vez, con la mística judía. La evidencia de un acontecimiento no es más que una realidad limitadamente interpretada $\mathrm{y}$, por lo tanto, problemática, además de vacilante.

Gianni Vattimo ha llegado a formular que en la posmodernidad se ha ingresado a una babel informativa. En este recinto, los medios y la comunicación en general obtienen un carácter preponderante. Es por ello que él rechaza las grandes verdades, las concepciones unívocas de los modelos herméticos, además de los fundamentos coherentes de la historia. La posmodernidad abre el camino, según Vattimo, a la infinidad y a la tolerancia (Vattimo, Después de la cristiandad, por un cristianismo no religioso 73 )

Esta es la misma estética que promulga Barnatán en Laberinto. Marcos Ricardo Barnatán hace notoria la idea de que la religión cae en el pecado cuando comienza a abogar por la segregación de Dios, a olvidar que el verdadero santuario no tiene paredes. Siempre ha mostrado la religión una proclividad a convertirse en un fin en ella misma, a recluir lo sagrado, a tornarse estrechamente lugareño, autoindulgente, egoísta, como si su misión no fuese ennoblecer la naturaleza humana sino acrecentar el poder y la belleza de sus propias instituciones o ampliar su cuerpo de doctrinas. 
Con frecuencia se ha hecho más por canonizar los prejuicios que por defender la verdad, por petrificar lo sagrado, que por santificar lo secular. Esta puede ser una razón por la que Barnatán, en su primera novela posmoderna, rechaza los grandes modelos fijados y cerrados a la infinidad.

Vattimo se ubica al lado de la diversidad. Él desafía la identidad que se hace notoria en nuestra época en la homogeneización. Su credo se apoya en "la estética de la diferencia que sale al encuentro a la globalización para luchar contra ella" (83). Vattimo opta por una sociedad más justa en la que se respeten las diferencias. Barnatán también tiene su mirada puesta en el futuro. Lo que nos viene a presentar Barnatán en Laberinto es que ni siquiera las leyes de la Torá son absolutas ${ }^{88}$. Nada es deificado: ni el poder, ni la sabiduría, ni los héroes ni las instituciones. Atribuir cualidades divinas a cualquier cosa, por elevada y sublime que sea, es distorsionar la idea que ella representa y a la vez el concepto de lo divino del que la imbuimos. Barnatán critica y se alza en contra de la tendencia del hombre a convertir lo instrumental en final.

En el posmodernismo y en la mística, Barnatán obtuvo la idea de una novela donde se puedan mezclar elementos dispares, sugiriendo así que en cualquier discurso es posible encontrar parte de una disertación mucho más cósmica que en los textos ya establecidos y canonizados.

Barnatán desvaloriza la idea que da por sentado que solo en los textos sagrados puede ser encontrado un conocimiento sólido y trascendental. Según Barnatán, solo rechazando este tipo de creencias se podrá construir un nuevo esquema

\footnotetext{
${ }^{88}$ La explicación que Harold Bloom da a este fenómeno es que los textos tienen un significado inestable y esta es, según este crítico, la contribución sustancial de la Cábala a la hermenéutica moderna. "La gran lección que la Cábala puede enseñarle a la interpretación contemporánea consiste en que el significado de los textos [...] es siempre un significado errante, tal como los judíos del exilio que fueron un pueblo errante. Va errante el significado, como la humana tribulación o el error, de texto en texto, y, dentro de un texto, de figura en figura ${ }^{88}$.
} 
de valores y relaciones, e intenta a través de esta estética democratizadora unir la novela con la vida.

En la obra El laberinto de Sión, la realidad y la ficción colaboran en el mismo espacio - tiempo, e incluso este autor propone una duda inteligente: ¿cómo se sabe cuál es la ficción y cuál la realidad? ¿Con qué criterios medimos estos acontecimientos? ¿Son válidos estos criterios aun hoy? Esta idea es la que Barnatán intenta capturar en su primera novela, que es semejante a un filme donde los dibujos animados comparten el mismo escenario que un actor real.

Barnatán propone para el hombre una afirmación del mundo, pero sin esclavizarse a él; propone ser parte de la civilización y trascenderla, conquistar el espacio y santificar el tiempo.

Esta es la razón por la cual en la obra de Marcos Ricardo Barnatán, en especial en El laberinto de Sión, se desarrolla una nueva mímesis realista, producto de la consideración del mundo como problema ontológico y no solamente epistemológico. En Laberinto se reconfigura y se da un nuevo tratamiento al lector, al narrador, a los personajes como consecuencia de la consolidación del sujeto débil de la representación, además de jugar con los espacios heterotópicos. Barnatán opta por espacios plurales para que en ellos puedan convivir perspectivas disímiles que hacen que el individuo pueda obtener un lúcido enfoque de lo externo.

Otro recurso que en El laberinto de Sión se suele percibir y es una característica del posmodernismo es la eliminación del narrador omnisciente. De esta manera, Marcos Ricardo Barnatán puede mezclar diversas y variadas perspectivas. "Esta ideología posmodernista se manifiesta estilísticamente a través de formas carnavalescas e híbridas y también abiertas a la intervención del lector” (Foster, The Anti - Aesthetic: Essays on Postmodern Culture 45). Se hace en muchos casos 
referencia a fragmentos de textos místicos, muchos de los cuales suelen ser poéticos, pero de una forma muy poco convencional y sin ningún tipo de reverencia. En Laberinto, además, se hace una gran reflexión sobre el acto de escribir. Barnatán confirma que narrar en el orden que espera el lector ya no es probable. En la novela $E l$ laberinto de Sión, las experiencias son como montajes de imágenes interrumpidas, como videoclips. En un plano microestructural, Barnatán prefiere una puesta en escena de un antidicurso donde prevalezca la polifonía.

Este mismo escritor "se siente cautivado por el vínculo entre la literatura y la cultura popular y encuentra en el posmodernismo un medio idóneo para la solidificación del fenómeno masificación del arte" (Harvey, La condición del postmodernismo 89). Según Barnatán, la integración de los códigos masivos y los código canónicos son cruciales para el desenmascaramiento de la realidad. El desconcierto último que Barnatán presenta en Laberinto está relacionado con esta integración de códigos. Esta integración depende de la infinita responsabilidad sin sabiduría y del poder eterno que posee el hombre dentro de la sociedad.

Marcos Ricardo Barnatán coincide con el ataque que Vattimo hace a la cultura y a la sociedad. Vattimo alerta del peligro de los medios masivos de comunicación ya que son estos los que construyen la realidad. "Los medios masivos cumplen con lo que señala Nietzsche: la transformación de la realidad en fábula, el enmascaramiento de lo real" (Vattimo, Diálogo con Nietzsche 61). Son los medios los que decretan qué es un hecho, qué ocurre y qué es lo que es verdad.

El nihilismo que se halla administrado en los estratos de la hermenéutica posmodernista "se manifiesta en el ámbito de lo social como secularización" (Vattimo, Nihilismo y emancipación: ética, política y Derecho 95). Y este es el nombre que da Vattimo a lo que está ocurriendo en la sociedad posmoderna. Se ha 
secularizado el Estado, en el sentido que se ha apartado de la religión, y Vattimo cree que la religión misma debe secularizarse para no ser fuerte sino débil, para estar en verdad del lado de los débiles. De manera que "pensamiento débil" quiere decir que se está del lado de la diferencia, de las minorías, y también de los marginados, que son mayorías.

3.1.1. El espacio como medio para vivenciar la multiculturalidad en El laberinto de Sión

Es curioso advertir que en el arte, en la política o en la ciencia, el poder se obtiene a través del discurso. "El discurso es una agresión que se practica sobre los conceptos preconcebidos por el individuo" (Alazraki, Borges, entre la modernidady la postmodernidad 41). Las exigencias de objetividad efectuada en nombre de discursos determinados siempre son ficticias; no se encuentran discursos auténticos sino discursos poderosos.

Por otra parte, la fragmentación de la totalidad conduce a la fragmentación de los sujetos y de los proyectos. Esta es la razón por la cual no habría categoría de análisis sobresaliente ni favorecida. "La desestructuración de la totalidad no es aquí meramente fruto de una concepción de la sociedad desarticulada en oposición a una unitaria" (Feyerabend, Contra el método 19), sino la secuela de una idea de discernimiento regulado esencialmente por la cultura (ordenes epistémicas de Foucault) y por el poder. Es por ello que el nihilismo y desestructuración de la totalidad van de la mano. Recuérdese que el nihilismo niega todo lo que ostente o manifieste un propósito o una intención superior.

En general, el posmodernismo que irrumpe en todos los recintos de la vida de las sociedades contemporáneas "estimula a la disolución de todo aquello que se había 
determinado como representación universal: esquemas generales en todos los terrenos a los que todas las sociedades se habrían de adaptar o adecuar" (Anderson, Los orígenes de la postmodernidad 65). Es por ello que, en ese sentido, se advierte que el posmodernismo simboliza la terminación de la historia, el fin del sujeto y de las ideologías. En su lugar prevalece, se transcribe y hace ordinaria "la existencia de la desigualdad, se conquistan los conceptos, las entidades o los objetos por su individualidad, por sus exclusivas características y valores privativos” (75).

En ese sentido, el posmodernismo encarna todo un nuevo periodo en la vida del individuo donde impera, por así llamarlo, "una mayor autonomía para la actividad humana, ya que no se está subyugado a paradigmas o a modelos habituales de operar" (94). La autonomía y lo concreto alcanzan un nuevo valor en la vida del hombre y de las sociedades.

Para recapitular, se puede señalar que la crisis de la totalidad se vincula con la de los magnos discursos. El posmodernismo es el corolario de la pérdida de legitimidad de los discursos colosales y la expansión de juegos verbales con sus reglas. "El posmodernismo rasga la atadura unificadora y ocasiona la diseminación de los sujetos" (Vattimo, En torno a la postmodernidad 18).

El discurso de la multiculturalidad está dividido entre los movimientos sociopolíticos y los académicos. Las ciencias humanas y sociales perciben a las identidades como tradicionalmente fantaseadas, representadas y reivindicadas.

Ambos procesos —el de la transnacionalización y el de la hibridación— hacen que disminuyan los antiguos arraigos territoriales. Sin embargo, muchas organizaciones sociales y también políticas "conciben absolutizar el territorio originario por etnias y por las naciones y manifiestan que las características telúricas y biológicas están asociadas con el origen, como si no tuviera nada que ver con los 
incidentes históricos" (Lyon, Postmodernidad 53) y a las variaciones

contemporáneas. En las disputas internacionales e interétnicas se hallan propensiones acérrimas por concebir cada identidad como un centro sólido y rígido potencializador.

La protección de la integridad impera en muchos países, a diferencia de las corrientes modernas que intentan relativizar lo particular en cada nación, en cada etnia, con el objetivo de erigir formas más convenientes de coexistencia y de autoridad multicultural. "El nacionalismo político, así como el romanticismo folclórico, se aunaron para conseguir que los gremios de los movimientos étnicos y socioculturales quedaran establecidos en menos contenedores políticos territoriales, llamados naciones" (Arocena, La modernidad y su desencanto 12).

De esta forma se fijó que los ciudadanos de una cierta extensión territorial tenían que corresponder y referirse a una cultura homogénea y poseer por tanto una típica, aislada y única identidad que, al mismo tiempo, tenía que ser congruente con las demás. Todavía hoy, la creación literaria y artística en general sigue concibiéndose como expresión de mitos nacionales y Laberinto así lo recrea:

Recuerde usted a Erenbourg, un judío tantas veces proclamado comunista; hasta Erenbourg dijo: "Yo proclamaré siempre que soy judío, mientras quede en la tierra un antisemita. Y no es el nacionalismo el que me hace escribir esto, sino mi sentimiento de dignidad humana”. Yo se lo repito hoy a usted, guiado por mi sentimiento de la dignidad humana y también por mi nacionalismo. Nacionalismo, nacionalismo, eso suena tan mal [...] (77)

Muchas veces "la literatura y las artes plásticas se mantienen como surtidores del imaginario nacionalista configurando parte del contexto de consagración de los símbolos de las identidades regionales” (Vásquez Rocca, La postmodernidad 13), hecho este al cual Ricardo Barnatán se opone.

Un gran número — cada vez más vasto — de sectores de la producción artística se crea en circunscripciones de nadie. "Ellos exponen en sus obras una conciencia 
cosmopolita que en gran parte abona el terreno a su repercusión internacional”

(Gadamer, El giro hermenéutico 39), y por qué no, se puede arriesgar el comentario y plantear que incluso su trascendencia puede, incluso, ser cósmica, como es el caso de Barnatán.

El escritor que ocupa este trabajo, Marcos Ricardo Barnatán, defiende un tipo de literatura "que transita más allá de los lindes establecidos, ya que va más allá de la propia imaginación del individuo y de sus anhelos" (Barnatán, La Kábala 75). Marcos Ricardo rotula la idea que las monoidentidades nacionales pueden desplazarse a los multiculturalidad global, y alerta que tintes de la primera pretenden subsistir bajo el latinoamericanismo y el sionismo.

El ejercicio que ha conseguido mayor verosimilitud en el continente latinoamericano es el fundamentalismo del premio Nobel Gabriel García Márquez. Este premio pondera al continente como el espacio donde el atropello la violencia y el ensañamiento social tienen lugar por antonomasia, y sitúa la heterogeneidad y multiplicidad de Latinoamérica en la integración cultural. En el discurso de aceptación del premio Nobel de Literatura de 1982 ante la Academia Sueca, Gabriel García Márquez lo expresa así:

En las buenas conciencias de Europa, y a veces también en las malas, han irrumpido desde entonces con más ímpetus que nunca las noticias fantasmales de la América Latina, esa patria inmensa de hombres alucinados y mujeres históricas, cuya terquedad sin fin se confunde con la leyenda. No hemos tenido un instante de sosiego. Un presidente prometeico atrincherado en su palacio en llamas murió peleando solo contra todo un ejército, y dos desastres aéreos sospechosos y nunca esclarecidos segaron la vida de otro de corazón generoso, y la de un militar demócrata que había restaurado la dignidad de su pueblo. Ha habido cinco guerras y diecisiete golpes de Estado, y surgió un dictador luciferino que en el nombre de Dios lleva a cabo el primer etnocidio de América Latina en nuestro tiempo. Mientras tanto, 20 millones de niños latinoamericanos morían antes de cumplir dos años, que son más de cuantos han nacido en Europa desde 1970. Los desaparecidos por motivos de la represión son casi 120.000 , que es como si hoy no se 
supiera dónde están todos los habitantes de la cuidad de Upsala. Numerosas mujeres encintas fueron arrestadas y dieron a luz en cárceles argentinas, pero aún se ignora el paradero y la identidad de sus hijos, que fueron dados en adopción clandestina o internados en orfanatos por las autoridades militares. Por no querer que las cosas siguieran así, han muerto cerca de 200000 mujeres y hombres en todo el continente, y más de 100000 perecieron en tres pequeños y voluntariosos países de la América Central: Nicaragua, El Salvador y Guatemala.

Gabriel García Márquez señala la inverosimilitud y lo absurdo de la realidad del continente ${ }^{89} \mathrm{y}$ hace de estos dos conceptos una hipótesis inherente de Latinoamérica. Como vemos, estos conceptos, juicios y consideraciones se enfrentan a las lecturas constructivistas de la multiculturalidad.

A los políticos les falta el sentido suprapolítico, que podría enseñarles lo que es de verdadero interés para la nación, más allá y por encima de sórdidas consideraciones. Por otro lado, a los hombres de principios les falta la visión de lo que debe y puede hacerse y en qué grado, en este mismo momento.

Muchos escritores consideran que los políticos son déspotas por las ansias de poder, que no conocen ninguna ley más allá de su voluntad, mientras que por otro lado los políticos ven a los escritores como cautivos de una retórica de gran complejidad; más apropiados a vivir en las nubes que en una tierra llena de contradicciones. Entre unos y otros se pierde toda la posibilidad de alcanzar el grado de bien y de lo que es correcto para relacionarnos con la realidad.

Por otro lado y como ya se ha mencionado, el sionismo pretende, como el latinoamericanismo, subsistir bajo el rótulo de la monoidentidades nacionales. La palabra sionismo se deriva del término Sión (uno de los nombres bíblicos de la ciudad de Jerusalén). Este nombre se refiere a un cerro cercano a Jerusalén. Durante el

\footnotetext{
${ }^{89}$ Véase para más información José L. Méndez: Como leer a García Márquez: una interpretación sociológica. Editorial de la Universidad de Puerto Rico, 2000.
} 
reinado del rey David, el término sión se convirtió en una sinécdoque para representar a toda la ciudad de Jerusalén y también a todo Israel. En muchos versículos bíblicos, los israelitas fueron citados como los hijos de Sión.

El término fue puesto en circulación por Nathan Birnbaum, de origen judío y fundador del movimiento estudiantil judío Kadima en 1890. Según los historiadores Walter Laqueur ${ }^{90}$ y Jack Fischel ${ }^{91}$, el término sionista es usado como un eufemismo para los judíos.

Los judíos han vivido en el exilio desde el siglo I de nuestra era, y siempre ha habido una presencia constante de judíos en la Tierra de Israel. Lo que plantea la Torá y el judaísmo es que Sión o la Tierra de Israel es la tierra que Dios ofreció a todos los judíos y, con ello, a la humanidad.

Después de la subversión de Bar Kojba, que duró tres años (132-135), los judíos fueron echados de Sión, lo que dio lugar al éxodo judío. Desde siempre se halló entre los judíos del exilio una gran añoranza de principio religioso de regresar al territorio histórico del pueblo judío. Ya en el siglo XIX comenzó a secularizarse, debido a que entra en contacto con tendencias ideológicas europeas de la época, como el socialismo, el liberalismo y el nacionalismo.

El origen del sionismo está enlazado con la aparición, en el siglo XIX, de los nacionalismos en Europa. Análogamente a ese desarrollo nacionalista, apareció el moderno antisemitismo. El sionismo sostenía que los judíos eran primordialmente un grupo nacional y no un grupo religioso y que, como tal, tenía derecho a crear su propio Estado en su territorio histórico.

\footnotetext{
${ }^{90}$ Véase: The Impact of Westem Nationalisms: Essays Dedicated to Walter Z. Laqueur, Londres: Sage, 1992.

${ }^{91}$ Véase El holocausto (1988). Jack Fischel suele ofrecer clases en Florida International University. Una de las clases más populares es "The effect of Jews on Pop Culture".
} 
La idea sionista, hasta el Holocausto, luchó con otra tendencia potencialmente extendida en Estados Unidos y Europa. "Esta ola ideológica no consideraba a los judíos como pueblo, sino como grupo minoritario religioso que tenía que integrarse en las sociedades en las que pertenecían" (Fischel, El holocausto 37). La forma exagerada de esta idea ponderaba incluso la abdicación a la religión hebrea.

El sionismo fusiona dos módulos: la identidad judía está centrada por una parte en la Tierra de Israel, y por otra, en la emancipación y soberanía. A través de todos estos años, "un sinnúmero de escuelas de pensamiento ha desarrollado diferentes estéticas, ya que los sionistas descendían de orígenes y grupos nacionales diferentes" (81). Se encontraban entre ellos como judíos alemanes, rusos, polacos, americanos, españoles. El sionismo alberga en su seno variadas ideologías.

Por último, sería interesante destacar que ha existido siempre sobre el sionismo una gran controversia. En el Talmud (Ketubot 111a) se menciona que el pueblo judío tiene que garantizar inexcusablemente que no se arribe a la Tierra de Israel usando la fuerza ni en grupo. Tampoco el pueblo hebreo debe rebelarse contra las naciones. Según el mismo Talmud ${ }^{92}$, de esta forma no se retrasaría la llegada del Mesías $^{93}$.

Algunos grupos religiosos (Pshevorsk, Bobov, Satmar) consideran que la creación del Estado de Israel viola constantemente estos principios. Otros dirigentes religiosos reconocidos creen que el culto al sionismo puede llegar incluso a la herejía; sin embargo, aceptan el Estado de Israel.

\footnotetext{
${ }^{92}$ Las páginas del tratado Sanedrín del Talmud están plagadas de las más extravagantes formulaciones sobre la llegada del Mesías, que culminan en la afirmación de que el Mesías vendrá o en una época del todo pura o en una época del todo perdida. No puede sorprender que, en este contexto, el Talmud incluya en frío el comentario de tres maestros del siglo III y IV: "que venga, pero yo no quiero verlo" (Sanedrín, 98 ${ }^{\mathrm{a}}$.

${ }^{93}$ Véase, para más información, Scholem G., Conceptos básicos del judaísmo, p. 104.
} 
Lo que Barnatán propone en la novela El laberinto de Sión es mucho más profundo que lo que a primera vista parece. Sión incluye una memoria, una petición, y una enorme empresa. Sión es el escollo fundamental, es el receptáculo y el tálamo de la casa mesiánica de la humanidad.

El sionismo no es la propuesta indeterminada e infinita del alma de las naciones según la propuesta de Marcos Ricardo Barnatán, ya que Sión constituye todos los pueblos de la tierra "con sus peculiaridades y tradiciones, ya que ningún hecho, por exorbitante que sea, ha de quedar al margen de ninguna nación. Sión es para todos los pueblos de la tierra. Sión es para todos aquellos que no discrepan de la razón y de la fe" (Sternhell, Ni derecha ni izquierda: ideología fascista en Francia $81)$.

En Sión, la fe y el hombre no se manifiestan con dos naturalezas disgregadas con dinámicas propias y preceptos singulares, sino que se absorben hasta el punto de lograr que la fe tenga como soporte a la humanidad, y esta última tenga como cimiento a la fe. El laberinto de Sión viene a formular un concepto verdaderamente profundo y cósmico: la esencia humana y la experiencia de fe convergen en la misma superficie, la cual sustenta a ambas. "A partir de este encuentro no se restringen a convivir intercambiablemente la fe por un lado y el hombre por otro, sino que forman la anhelada y deleitosa unidad" (Sternhell, Los mitos fundadores de Israel 23). Este concepto de unidad dentro de la novela Laberinto pareciera un tanto desfasado y obsoleto dentro del posmodernismo; sin embargo, no es así.

La novela de Marcos Ricardo a la que hace referencia este estudio reivindica lo múltiple y lo fragmentario frente a lo unívoco, además de defender lo polifónico y

\footnotetext{
${ }^{94}$ Véase para más información, The Anatomy of Fascism. Un artículo de Zeev Sternhell, Nueva York: Review Books, 12 de mayo de 2005.
} 
colectivo en oposición a lo uniforme e igual. A esto se añaden las complejas redes simbólicas a las que Barnatán crítica. Para este escritor, la insensibilidad de las formas, la monumentalidad asfixiante que en ocasiones tiene lugar en el discurso religioso, sumadas al dogmatismo del contenido de los libros canónicos religiosos, terminan ahogando el posible encuentro entre el individuo y una nueva forma de vida. Barnatán, sin embargo, no niega el propósito cósmico y de hecho presta atención y mucho interés al gran proyecto universal que Dios tiene con el hombre. Según el escritor, el proyecto divino descansa su pilar justamente en el individuo, y este sería su fragmento esencial. Entonces, ¿qué proyecto podría, por muy trascendental que sea, descansar sobre otra base que no sea el individuo? “¿Qué sentido tuviese este proyecto si no es concebido para el hombre; si no es el individuo su centro?" (Heschel, Dios en busca del hombre 37).

Marcos Ricardo, en Laberinto, pretende una síntesis utópica entre todo lo disgregado y lo monumental, como también ocurre en otras novelas colosales del posmodernismo. En Laberinto, esta síntesis se manifiesta en última instancia como inviable para el individuo, de ahí que ambos elementos — totalización y fragmentación - cohabiten en tensión dentro de la novela.

En Borges, biografía total, Barnatán insiste que es imposible abarcar el espacio en una única exposición, ya que "si lo miras desde su lado recóndito, desde las experiencias frecuentes, se pueden ver solo fragmentos, proximidades, lugares sujetados por una apreciación miope del todo" (94). Desde lo remoto se asemeja a una masa confusa que es complicado aplicar a la matriz fabricada por las teorías del orden. Borges — al igual que Barnatán — es de la opinión que es inviable determinar y seccionar un espacio, porque todos los espacios están en todos los lugares y, al mismo 
tiempo, no están completamente en ninguno, y es a esa grieta a la que se refiere

Laberinto en el siguiente fragmento:

Nada más monstruoso que comprobar el cierre hermético de todas las puertas, la inexistencia de un pequeño resquicio, de una grieta tan solo que nos permita huir, un orificio por el que corra el aire, aire libre, con derecho a entrar y salir. Nada más monstruoso que estrellarse ante la realidad del mundo (141).

Marcos Ricardo Barnatán coincide con Borges en que leer una novela no es solo trasladarse de una palabra a otra: es también superar un nivel y sobrepujar el próximo horizonte. Discernir unan novela no es únicamente escoltar el desarrollo de la historia: es, al mismo tiempo, inspeccionar los niveles, arrojar las conexiones horizontales del acaecer narrativo sobre ese imaginario eje vertical.

La lectura de El laberinto de Sión demanda “instaurar una correlación entre la interioridad y la exterioridad" (Jauss, La literatura como provocación 52), por lo que la dificultad mayor en la obra de Marcos Ricardo Barnatán es concretamente la imbricación de los niveles diversos y heterogéneos que se esparcen entre ellos.

La complejidad de los textos de Barnatán surge también del encuentro entre esos discrepantes niveles del texto, con algunos conceptos místicos pertenecientes a un pasado místico y remoto, que es, por lo tanto, histórico. Este hecho en la obra de Barnatán inmediatamente nos remite a Hans Robert Jauss ${ }^{95}$.

Este crítico alemán, importante exponente de la estética de la recepción, se esmeró por alcanzar un compromiso entre las teorías sociales (que no tiene en cuenta la historia) y el formalismo ruso (que hacen lo mismo con el texto). Jauss toma del filósofo de la ciencia T.S. Kuhn la noción de paradigma, es decir, el cuadro conceptual y los postulados vigentes en un periodo dado.

\footnotetext{
${ }^{95}$ Hans Robert Jauss (1921 - 1997) nació en el distrito rural de Goppingen, Alemania. Durante la Segunda Guerra Mundial formó parte de las Waffen SS. Es considerado como uno de los padres de la estética de la recepción.
} 
La ciencia suele "moverse en el interior del mundo mental de un paradigma concreto hasta que un nuevo paradigma desaloja al anticuado, esbozando diferentes dificultades e implantando nuevos postulados" (Jauss, Experiencia estética y hermenéutica literaria 86). Jauss utiliza los términos horizonte y expectativas para detallar los criterios utilizados por los lectores para juzgar textos literarios en cualquier periodo concreto.

Dichos criterios ayudan al lector a evaluar una obra literaria. "El horizonte de expectativas originales solo nos dice cómo fue valorada e interpretada la obra en el momento de su aparición, pero no constituye terminantemente su sentido" (Jauss, Las transformaciones de lo moderno 92). Según Jauss, sería tan desacertado decir que una obra es universal, como atestiguar que su significado está determinado para siempre y que se halla abierto a lectores de todas las épocas. "Una obra literaria no es una construcción artística que deja ver con un soliloquio su universo eterno" (Jauss, Las transformaciones 81 ).

Esto significa, por supuesto, que nunca se es capaz de explorar los sucesivos horizontes desde el instante de la aparición de una obra hasta nuestros días, para luego, con total alejamiento y objetividad, llegar a su valor o sentido definitivo. Esto sería no tener en cuenta la propia situación histórica. Llegados a este punto, puede surgir la pregunta: ¿Qué facultad es la que se debe aceptar: la de los lectores primeros o el cúmulo de experiencias derivadas de todos los lectores de todos los tiempos? Tal vez los lectores inaugurales pueden haber sido incapaces de percibir el significado revolucionario de un escritor. El mismo razonamiento puede emplearse en las reflexiones de los lectores posteriores, incluidos los contemporáneos.

Las respuestas que Jauss da a estos argumentos provienen de la hermenéutica filosófica de Hans-Georg Gadamer, discípulo de Heidegger. Georg Gadamer sostiene 
que "todas las disquisiciones de la literatura del pasado brotan del diálogo entre el presente y el pasado. Las tentativas de comprender una obra obedecerán a las preguntas que el contexto cultural actual consienta trazar" (Gadamer, El problema de la conciencia histórica 107), y al mismo tiempo, de revelar aquellas respuestas que la obra ha pretendido manifestar en su propia plática con la historia.

El semblante presente siempre involucra una correspondencia con el pasado que solo puede ser percibida desde esa posición circunscrita. Forjada en tales términos, "la tarea es instaurar un conocimiento del pasado parece una voluntad ineficaz" (Gadamer, Los caminos de Heidegger 28). Pero la noción hermenéutica de comprensión no separa al observador del objeto como lo hacía la ciencia empírica, sino que lo considera como una fusión del pasado y del presente; es imposible emprender un viaje por el pasado sin llevar al presente.

La palabra hermenéutica se aplica a la interpretación de textos sagrados y su equivalente moderno conserva la misma actitud formal y reverencial hacia los textos a los que intenta acceder. Jauss se muestra de acuerdo con la idea de que un autor puede alcanzar un enfrentamiento ${ }^{96}$ cara a cara, directamente, con las perspectivas sobresalientes de su tiempo. Esta es la razón por la cual se advirtió cierto descontento ante el método planteado por Jauss que registra sus propias restricciones históricas, pero que se siente con el impulso suficiente para suponer que otros comentarios presentan argumentos mal planteados o incoherentes.

Llegados a este punto, se puede plantear que la anexión o vinculación de los horizontes no es, según parece, la unión total de todos los puntos de vista que pueden haber brotado, sino solo la de aquellos que para el sentido hermenéutico del crítico

\footnotetext{
${ }^{96}$ Véase El giro hermenéutico de Jauss.
} 
aparecen como parte de la gradual y emergente totalidad de sentidos que conforma la verdadera unidad del texto.

\subsection{LA TORÁ: UN EJEMPLO DE TEXTO POLIFÓNICO POSMODERNISTA}

La exégesis, como forma de acercamiento a Dios y como acto que permite entrar en contacto con las diversas formas del texto y del mundo, se sitúa en el tiempo. Ninguna actividad humana puede sustraerse a ese peligro que la mide y condiciona, que marca su naturaleza parcial y finita. La Torá, sin embargo, es concebida por la tradición judía como un texto cósmico. Se la considera una entidad preexistente que no solo precede a la formación del mundo sino que también sirve como paradigma de su creación.

La Torá contiene el conjunto del conocimiento celeste y humano, y su estudio es un imperativo religioso. "Ni siquiera Dios está exento de tal obligación” (Pinjas, Comentarios 37). Su estudio de la Torá llegó a ser un leit motiv del pensamiento rabínico. La Torá es vista, en algunos textos rabínicos y en la mayor parte de los kabalísticos, como la "hija" de Dios.

En un Midrash remoto se dice que Dios contempló la Torá y creó el mundo. El autor de esta frase creyó, sin duda, que "la ley que rige la creación como tal, y en consecuencia, el Cosmos y la naturaleza estaban ya prefigurados en la Torá” (Pinjas, Comentarios 17), pudiendo de este modo ser observada por Dios cuando leyó en ella, si bien este aspecto del libro sagrado ha quedado oculto para el hombre.

Dos hechos son de gran importancia: en primer lugar, la naturaleza divina del estudio y la interpretación, acto que da lugar a la Creación misma y eleva el trabajo exegético humano a la más elevada categoría, sin olvidar, por otra parte, “que el hombre, cuando interpreta, se enfrenta al texto sagrado desde sus profundos 
obstáculos, intentando indagar su sentido desde un presente" (Jauss, El giro hermenéutico 32) y unas circunstancias siempre únicas y complejas.

Se trata de una cuestión de gran relevancia en cualquier reflexión hermenéutica, pues ¿cómo se acerca el lector a un texto que fue escrito en otro tiempo, influido por una serie de acontecimientos desconocidos, y es capaz de otorgarle un sentido que no existe a priori sino que se construye en la lectura, sin desvirtuarlo?

Heidegger dedicó buena parte de su obra a tratar estos asuntos, e imprimió la noción de la actualización del sentido. Por actualizar se entiende que lo escrito participe en un sentido presente, es decir, que tenga lugar una verdadera comunicación con el lector, y el texto vuelva a hablar a través de la historia hasta el presente más inmediato, donde tiene lugar el verdadero acto interpretativo. El arte de la interpretación consiste en esa actualización del sentido, que ofrece la oportunidad u ocasión de quebrar la forma cerrada de la escritura para hacer posible una relación con el texto. La hermenéutica es entendida como intermediación: una actividad que permite activar el sentido y atraerlo hacia el presente. La esencia del discernimiento, por tanto, no se relaciona con la reconstrucción del pasado sino con la intervención actual en lo dicho.

"Hay discursos, según sea su naturaleza, no llega ninguna interpretación a colmarlos ya que siempre hablan y éste es el caso de la Torá" (Gadamer, El giro hermenéutico 86). Otros, en cambio, se integran mentalmente en el lector hasta que el texto desaparece.

Sin embargo algo prevalece, y es el caso de las metáforas universales — por solo citar un ejemplo- , que según el tiempo y la cultura se encarnan de diferentes formas. Todo surgimiento remite a otro, toda novedad es una reaparición. Al aplicar 
tal principio a los escritos literarios, estos se presentan como textos perseverantes cuya transmisión, encargada a la filología, exige especial cuidado, y que sin embargo viven en una multiplicidad de motivos vehiculados por la tradición y por sus nuevos lectores.

Un clásico es una obra que nunca agota ni termina de expresar lo que tiene que exponer; toda nueva lectura de revelación es como la primera, lo cual implica que no hay lecturas que puedan ser consideradas como aventajadas en el sentido estricto del término. Al mismo tiempo, los clásicos son esas obras que nos llegan con la marca impresa de las lecturas que han antecedido y también con el vestigio que han dejado en las civilizaciones que han traspasado. Es decir, aquellas obras en que la tradición convive con el texto hasta el punto de que al lector le resulta imposible separarlos, o sustraerse a la influencia de la primera.

La Torá es algo más que un clásico. No hay otro libro que ame y respete de tal modo la vida del hombre. No hubo jamás cantos más excelsos para expresar la verdadera miseria y gloria del hombre, su zozobra y su alegría, su sufrimiento y su esperanza. La Torá no es un fin sino un principio, es un precedente no una historia. El hecho de hallarse inserta en situaciones históricas determinadas no le ha impedido ser eterna. No es una epopeya sobre la vida de héroes, sino la historia de cada hombre bajo todos los climas y en todas las épocas. Su tema es el mundo, el conjunto de la historia, y contiene las pautas para a constitución de una humanidad unida y elementos de orientación para plasmar esa unión. Es capaz de mostrar el camino de las naciones al igual que a los individuos.

La tradición judía, como ya se ha visto, vuelve una y otra vez sobre la palabra revelada, siempre idéntica en la forma y múltiple en su significado. Más allá de las consideraciones hermenéuticas que se han hecho hasta ahora, es necesario tener en 
cuenta que a los intérpretes de la Torá les ha sido delegada la tarea de poner al día el mensaje divino, de ayudar a Dios — un Dios en parte exiliado y desterrado- a revelarse.

\subsection{LA RESPONSABILIDAD DEL HOMBRE ANTE EL TEXTO. LA REALIDAD COMO INVENCIÓN CONSTANTE}

En la literatura rabínica existen diversas escuelas hermenéuticas y de pensamiento, entre las que destacan, por contraste, la de Rabí Aqiba y la de Rabí Ismael:

Característico de la escuela de Aqiba es el método de conseguir una "ampliación" o una "reducción" de la significación de un texto, así como la explicación de todas las sutilezas lingüísticas, tales como los dobletes de expresiones, incluso las particularidades sutiles de palabras y letras. Por contra, R. Ismael y su escuela tienen una marcada preferencia por el sentido literal del texto, pues "la Torá habla el lenguaje de los hombres" (The Kabbalah and its Symbolism 176).

Aqiba insiste en que toda la tradición, tanto la ley oral como la escrita, está implícita en la escritura. Aqiba interpreta hasta la forma de las letras, los signos de puntuación, el ritmo, prestando atención a las palabras gramaticales y las conjunciones. Los kabalistas compartían esta visión e idearon diferentes formas de actualización del texto divino. Esta idea es compatible con la teoría de Foucault. El discípulo norteamericano más destacado de Foucault —Edward Said—, siguiendo la lógica de las teorías de Foucault, plantea que no hay ningún discurso fijado para siempre, "el discurso es al mismo tiempo causa y efecto" (Said, Orientalismo 78). No solo ejerce el poder, sino que también estimula la oposición.

La idea subyacente es que, tras la Creación y la entrada de la palabra de Dios en la historia, el hombre no tiene otra forma de acercamiento a ella que la actualización de su mensaje. "Solo descubriendo el carácter secreto de las Escrituras y 
atrayendo su profundo misterio hacia el presente podrá tener lugar la revelación esperada" (Madirolas, El camino 72).

Un famoso Midrash ofrece a los místicos la justificación teórica para sus aventuras hermenéuticas. En él se cuenta que Moisés, que habría sido autorizado siglos después de su muerte a escuchar una explicación de sus enseñanzas en la escuela de Aqiba, no reconoció nada de lo que allí se decía. Preguntó a Dios qué estudiaban, y este, para su desconcierto, le contestó: "Es tu ley. Existe la ley de Moisés para los tiempos de Moisés y la ley de Moisés para los tiempos de Aqiba”. La propuesta es de una radicalidad extrema, pues otorga al hombre la facultad — y quizá no solo la facultad, sino la obligación también— de reubicar el texto bíblico adaptándolo a las circunstancias del momento, pero sin olvidar su letra, eterna e inamovible. La ley de Moisés cambia según los tiempos, y sin embargo sigue siendo la ley de Moisés.

La proyección de un sentido secreto ayuda al texto no solo a sobrevivir a nuevas situaciones o a extender su influencia, sino también a enriquecer el presente. Dios entregó la Torá, y al hombre le corresponde explorar sus potencialidades, descubrir, desde su naturaleza histórica, el incesante vínculo entre el texto sagrado y la Creación.

Al no estar escritas las vocales en la Torá, y dada la estructura de las lenguas semíticas $^{97}$, por el simple hecho de articular las palabras el lector se transforma en un intérprete. Una misma sucesión de consonantes puede dar lugar a distintas palabras

\footnotetext{
${ }^{97}$ Una misma raíz consonántica puede adquirir diversos significados por un procedimiento denominado "interdigitación". La raíz y el tema (vocales, afijos, reduplicaciones) se entrecruzan y dan lugar a amplios campos de relaciones semánticas.
} 
según su vocalización ${ }^{98}$, lo que cambia el sentido de las oraciones. Y todo esto sin modificar el texto canónico en modo alguno.

El kabalista afirma que, si debemos vocalizar el rollo de la Torá, este recibirá un límite y una medida, como el alma que recibe una forma peculiar, y solo podrá ser interpretado de acuerdo con la vocalización específica de una palabra determinada. La libertad de interpretación, en este caso, está relacionada con la prohibición de vocalizar la Torá. El texto bíblico es, desde este punto de vista, la piedra de toque de las capacidades humanas. Su potencial infinitud, sin embargo, no depende completamente de nuestra capacidad para actualizarlo, sino que es inherente a su peculiar estructura. La lectura kabalística es un acto de cooperación con Dios: así debe ser entendido el concepto de actualización de lo divino.

Las diferentes maneras de interpretación son rituales que tienen como meta la instauración de una adherencia más profunda entre Dios y el mundo a través de los reiterados intentos de acercamiento al texto, y de la creación de nuevas técnicas exegéticas. El movimiento jasídico da otra vuelta de tuerca a la cuestión interpretativa.

"Los actos humanos son concebidos como una actualización de la potencialidad divina. A través del comportamiento, se provoca el acercamiento o el alejamiento del hombre hacia Dios" (Heschel, Dios en busca del hombre 24).

Tal poder implica una gran responsabilidad. El jasidismo convierte la interpretación en una ética, y la búsqueda de nuevas formas en una necesidad, una

\footnotetext{
${ }^{98}$ Durante siglos, el hebreo se escribió solo con letras consonantes; el lector añadía las vocales en la lectura. Sin embargo, en la época de los masoretas (siglo VIII de la era común), la pronunciación correcta del hebreo se iba perdiendo a causa de que muchos judíos ya no hablaban ese idioma con fluidez. Grupos de masoretas ("conservadores de la tradición": grupos de escribas que copiaron el libro sagrado y se preocuparon de su correcta transmisión) de Babilonia e Israel inventaron unos signos que, colocados junto a las consonantes, indicaban la pronunciación y la acentuación correctas. Se crearon por lo menos tres sistemas, si bien el que se impuso fue el de los masoretas de Tiberiades, ciudad ubicada junto al mar de Galilea.
} 
obligación del ser humano ante Dios y ante el mundo: el trabajo hermenéutico tiene consecuencias, entonces, cosmológicas.

Menachem Mendel Schneerson, conocido como el Rabí de Lubavitch, concibió la Creación como un proceso continuo, y sostiene que las innovaciones en el estudio afectan a la esencia de la Torá y son el origen de todas las transformaciones que se originan en el mundo. "A través de un estudio nuevo y fecundo el hombre puede cooperar con Dios en esa creación constante (Knight, Simbolismo cabalístico 51). De acuerdo con la idea jasídica, la Torá reglamenta los desarrollos subsiguientes a la Creación, que emula con el estudio de la Torá.

El lector - intérprete, para orientarse ante tales exigencias, ha de seguir un camino ajeno, pero nunca alejado de él mismo. La mayor sorpresa, la fortuna más deseada, es en realidad lo más inmediato, pero para llegar a ello es necesario alejarse, partir, explorar al otro, viajar; exiliarse (Barnatán, Antología del Zohar 34).

El hombre, según la ética jasídica, ha de estar en continuo movimiento, partir e investigar, y de este modo encontrar su trayecto, el único que a él le pertenece.

Rabí Najmán, descendiente del Baal Shel Tov, solía decir: "No preguntes a nadie que conozca tu camino, porque entonces no podrías alejarte de él”. (Más allá de toda duda: evidencias convincentes sobre las verdades del judaísmo, 138)

Este brevísimo relato esconde, con fina mordacidad, uno de los elementos fundamentales del jasidismo: la invitación a innovar, la obligación, incluso, de ser creativo. "Un hombre verdaderamente piadoso es aquel que hace uso de todas sus facultades y va lo más lejos que le es permitido, es alegre y disfruta de los placeres de la vida" (Díaz, El humanismo de Martin Buber 47); un hombre que recorre su propia senda, con decisión, bravura y entusiasmo. Si Dios ha de juzgarlo de algún modo, será 
por la intensidad de esa búsqueda, por su tesón en ese recorrido íntimo. Así, la imitación, aunque sea de los virtuosos, ha de quedar fuera de todo deseo de redención.

La lectura participa de esa ética de la diferencia y de la acción. No hay barreras entre el texto y su intérprete: se lucha contra la elevación del Libro, de los textos sagrados a la categoría de ídolos intangibles. La palabra es plural, y así también las versiones e interpretaciones (Tresoldi, La Cábala 123).

Comprender un texto es aplicarlo a uno mismo. Pero teniendo en cuenta, como se anunció antes, que esta aplicación no lo agota, pues puede ser entendido de otras muchas maneras diferentes: el lector y traductor - intérprete existencialmente confrontado a los textos no intenta nunca, en un primer momento, volver a una vida pasada, a un sentido del pasado. Su comprender significa participación presente en lo que es dicho. "La innovación, lejos de generar desconfianza, es un deber humano" (Buber, ¿Qué es el hombre? 73).

El hombre jasídico es el hombre del hidouch, de la novedad. De este modo, la ética está atada a la hermenéutica; esta última no hemos de entenderla solo como experiencia de la comprensión semántica, sino que encarna una actitud fundamentalmente existencial, que permite la invención de uno mismo. La ética jasídica sostiene que todos tenemos el deber de buscar la libertad de inventar otras formas de experiencia. La realidad, pues, es plural, y la identidad se construye sin fijarse nunca, como invención constante. El hombre jasídico tiene la mirada puesta en el futuro.

3.3.1. La creación literaria instalada en un espacio más significativo, incluso por encima de los sucesos

La innovación reactiva y el poder del lenguaje de Marcos Ricardo Barnatán lo liberan del peso de un pasado que, cual carga, ahoga su significación plural. Su 
narrativa se esfuerza en esta tarea rescatando las palabras de la comunicación cotidiana, pero no para devolverlas al lugar de donde surgieron, sino para otorgarles un espacio distinto, renovado. El movimiento nunca es regresivo, sino que se proyecta hacia delante intentando construir un sentido para la historia y para la vida.

La noción de influencia, en este estudio, se concibe en términos muy semejantes. Marcos Ricardo Barnatán, en su relación con la Kábala, parte de unos presupuestos muy parecidos a los que se acaban de presentar (aunque de forma más o menos explícita), pues de ningún otro modo hubieran podido sacar de esa tradición una utilidad artística. En un espléndido giro, aborda la tradición mística judía sirviéndose de los mismos procedimientos hermenéuticos que la fundan y la han hecho avanzar a lo largo del tiempo. ¿Sincronía o casualidad? Tal vez sea producto de la pura necesidad a la hora de rescatar textos del pasado y hacerlos corresponder con los principios de la exégesis judía y las exigencias de cualquier lectura secular, comprometida con la realidad y con la propia vida.

El robo, se convierte, entonces, en una necesidad apremiante. Robo estimulado, avidez iniciadora que no atiende a razones, que advierte en todo aquello que pueda serle útil, sin límites, sin miedos ni convencionalismos. Llama la atención, igualmente, la benevolencia con que se juzga a los ladrones en numerosos cuentos jasídicos. En uno, titulado "El ladrón fuerte”, son motivo de elogio; simbólicamente, por supuesto, pero sin olvidar tampoco que las metáforas jamás son de balde. Muy por el contrario, responden a la realidad más profunda, la que incita bajo la enseñanza, la que solo algunos, los más arriesgados, sabrán poner en práctica:

Toda cerradura tiene una llave que se ajusta a ella y la abre. Pero hay ladrones poderosos que saben abrir sin llaves. Violentan la cerradura. Así también cada misterio en el mundo puede ser descifrado por la meditación particular que le corresponde. Pero Dios ama al ladrón que 
fuerza el cerrojo. Quiero decir, al hombre que rompe su corazón por Dios (fuentes judías: leyendas del Talmud y del Midrash, 237).

La explicación de la metáfora, su término real, aparece citado al final: romper el propio corazón por Dios. No seguir el camino trazado, el que sin duda lleva a la meta, sino, una vez más, ladearse, tentar la suerte, transitar por parajes a los que no se ha sido encauzado.

Apropiarse de lo que a uno no le pertenece, y hacerlo furtivamente, en un acto que es al mismo tiempo manifestación y exabrupto. Lo realmente mágico de la experiencia quizá sea que el robo no empobrece la fuente. La utiliza en toda su complejidad, comprimiéndola al máximo, pero conservándola igual de seductora para el próximo viajero. Aunque modificada, siempre prolífica y opulenta.

Tal es el caso del lenguaje en el caso de la obra artística literaria. “¿Se puede agotar?", han llegado a preguntarse, atribulados, algunos escritores. Y a pesar del mal uso que a menudo se hace de él, de su vacuidad o nimiedad en tantas bocas, o de los perfectos hallazgos que ya nos ha brindado, su potencial creador parece haberse mantenido intacto, a la espera de quien sepa extraerlo. Una casa, íntima y secreta, moldeable a gusto de todos, a partir de la cual se pueden forjar tantos caminos como individuos haya.

El judaísmo interpreta las Escrituras impregnado de esta misma convicción. Nadie podrá llegar a consumirlas, porque eso significaría que Dios se ha vuelto perfectamente cognoscible e inteligible para el ser humano. Pero "nadie debe tampoco renunciar a indagar sus misterios, pues tal dimisión equivaldría a un abandono de lo humano" (Lyotard, La condición posmoderna 21), condición que es, ante todo, tentación hacia lo ignorado: robo, anhelo, deseo, serenidad y paciencia, deseo que deviene pregunta. Dios vive en los pormenores, en la pequeñez del texto, en los gestos 
profundos y escogidos, en las puntadas sin hilo, y esos detalles pertenecen a la actividad exegética humana que los revela y los halla, les concede una voz y un sentido.

Con esta idea en mente, Barnatán intenta crear en El laberinto de Sión un horizonte lingüístico, donde se inserten neologismos, frases en francés, alteraciones y descentramientos semánticos. Marcos Ricardo Barnatán sugiere una retahíla de dilemas, un husmear en el que el procedimiento y el pensamiento se van estructurando. La teoría en la que se respalda Barnatán, "no preexiste sino que se establece en la pericia" (Lyotard, Psicología postmoderna: el yo disgregado 52). La misma excursión a través de está estética puede provocar la desilusión en el lector, ya que le es inalcanzable el logro de este clímax si no está adiestrado para hallar la culminación. "Las dimensiones de la búsqueda y su expedición al futuro hacen que esta tarea sea de difícil acceso" (Buber, El humanismo hebreo y nuestro tiempo 73).

Por otra parte, la narrativa de Marcos Ricardo Barnatán es un atrayente y paradójico material para discernimientos sobre trabajos textuales. En todo momento en Laberinto existe una trágica angustia que suele acusarse cuando la literatura se interroga a ella misma, cuando ella no se admite como es y cuando sufre por la necesidad de expresarse esencialmente. Pero al mismo tiempo, a pesar de reconocer esa propensión del lenguaje, se lanza hacia un territorio determinado en que se puede alcanzar un convenio congruente de todos los componentes que la arman: la mística.

La Palabra Buscada. La Gran Sombra de la Palabra Buscada. Una cítara marca la palidez de un sonido muerto. Dieciocho lunas y la Palabra asumirán toda su potencia, alcanzará las puertas más altas, entrará en el Templo y será reverenciada por las multitudes anhelantes La Palabra que fue pronunciada y olvidad (Laberinto, 97). 
Es evidente que en El laberinto de Sión existen interpretaciones yuxtapuestas donde coexisten armonías veleidosas con límites diferentes, y es asunto que "el lector activo $^{99 "}$ colabore y las oriente.

La lectura de esta novela es la incógnita que tenemos bajo los ojos, y todo consiste en que el lector se haga partícipe también de ese secreto. La respuesta a los secretos que presenta el texto no es más que la exhibición de la alternativa y el desenlace es extratextual.

La aspereza de la lectura de Marcos Ricardo Barnatán deriva del hecho de que el lector se encara con una universalidad impracticable, al menos por ahora, donde cada trazo, cada referente cultural remite a una interpretación, es decir, a otra imagen y esta remite a un símbolo mucho más universal y por ello más cósmico.

El laberinto de Sión no sólo admite el concepto de literatura absoluta como acometió Borges, sino que se atiene a toda letra de cualquier texto, ya sean los humanos o el Divino.

La interpretación de El laberinto de Sión no es discreta ni evidente, requiere una lectura ardua. "Una lectura condensada y precisa donde la imagen se traduce a través de otras y la interpretación teórica redestina al lector a otros modelos” (Buber, Sionismo y universalidad 12).

Por un lado, el lector se ve forzado a practicar una lectura sintagmática donde la disertación y la historia corren juntas y el relato es el fruto de la propia realización del lector. Por otra parte, en la otra lectura vertical se cincelan correspondencias, analogías, entrelazados concéntricos que no son más que el empírico relato a decodificar. Es importante y vital señalar que el misterio literario no se encuentra en ninguna de estas dos lecturas. Para poder leer El laberinto de Sión en su totalidad hay

\footnotetext{
${ }^{99}$ Perspectiva cortazariana sobre el lector.
} 
que guardar esa creación interdiscursiva que existe entre ambos textos: el que se encuentra en el papel y el que se crea en la mente del lector. Sin embargo, toda lectura “aparta siempre componentes excedentes que no se pueden embeber en la mente del lector" (Gadamer, Arte y verdad de la palabra 11).

En el caso de El laberinto de Sión, esta pérdida que se anuncia como forzosa e inevitable puede ser lamentable. Si este descuido no se produce, los niveles se advertirían como más diáfanos — por supuesto los que están más a la mano—y ya los otros más profundos, que son los que en última instancia le interesan al lector y al escritor, quedarán al menos insinuados para que, en un prolongado e intenso trabajo, el lector intente revelarlos.

Marcos Ricardo Barnatán pide al lector que “demande el desdoblamiento del texto y de esta forma se producirá la transformación del orden lógico pudiéndose leer el relato que se encuentra oculto y en el cual se cumple con la verdadera deducción” (Gadamer, Mito y razón 109), la cual actúa como eje semiótico aprovechable y trascendental, y este no es más que el único que francamente ha querido escribir el autor. Esa es la razón por la cual en Laberinto no se respeta el argumento racional ni tampoco hay evidencias de anécdotas evidentes: todas ellas son difusas y vagas.

La invención literaria se instala en el espacio más significativo, incluso por encima de los sucesos. Para lograr el objetivo, los personajes se hacen indefinidos, como se ha manifestado, y los desafíos son insuficientes por carecer de polaridad. En Laberinto, Barnatán exhibe una voluntad inmensa por registrar los estados de ánimo o los estados de conciencia de sus personajes. Para ello, entonces, recurre a la introspección psicológica y a flashbacks, y ambos suelen ser insustancialmente detallados. 
Una característica común a todos los posmodernistas — en especial de los novísimos, como es el caso de Barnatán — es el modo de combinar o “crear el discurso hipertextual, en los que elementos de armonía y caos se subvierten con el fin último de favorecer las deliberaciones de distintos índoles" (Gadamer, Poema y diálogo 93), siempre bajo el signo de la consideración crítica. En este tipo de discurso usado por Barnatán en Laberinto es muy común hallar figuras que dan un nuevo carácter al espacio de la escritura, alejándose relevantemente de los conceptos establecidos del autor, lector y del propio texto.

En Laberinto interviene el protagonista héroe, Max, e incluso la tía del protagonista, Luna, para manifestar que lo que se narra no es un suceso, una realidad, sino que es un desarrollo intelectual y sensitivo que pasa por el acto de leer. El protagonista así lo expresa en un fragmento muy refinado:

Una tarde cuando leía distraídamente un descarnado poema del Adramandori de Milosz, aquel que habla de Leumel, "todo esto ya no es de aquí, Leumel, el hijo mío", el enigmático nombre del rey Salomón, su alter ego, mientras deletreaba sus jardines descendientes hacia el mar, sus ciegos jardines sin flores, descubrí de pronto un verso que me hirió como la descarga más fiera, como la metralla más traidora, como el puñal más hábil. "Es la terrible paz de los hombres sin amor". Entonces abandone el libro y corrí hacia un espejo. Frente al contorno de mi rostro lloré unos instantes lágrimas espesas y saladas. Estaba ante mí, otra vez, como hace mucho tiempo contemplaba mis lágrimas, mis ojos enrojecidos, mi cabellera revuelta, mi expresión descompuesta. Pero mi cerebro se mantenía lúcido, pensaba en Narciso entregado a la dulce ilusión de amar su imagen en las aguas. "Que tú brilles en fin, terme pur de ma course", exclamé en silencio, recitando los primeros versos de Valéry que mi madre me había enseñado a repetir desde niño. En seguida mi rostro recuperó la calma, sonriendo tristemente me sequé las lágrimas y con curiosidad observé la galería infinita que formaban los espejos al mirarme (Laberinto, 119-120).

En el contenido en Laberinto, a pesar de ser amplio y abierto, prevalece un proceso no alejado del individuo. Es una aproximación a sus dramas y angustias íntimas. Entre el argumento y el medio existe una relación desfavorable. Es evidente, 
incluso, la desconsagración del heroísmo del protagonista. El personaje héroe de $E l$ laberinto de Sión evoca todo lo opuesto a un suceso glorioso, intrépido o memorable.

Marcos Ricardo concibe la novela como un fragmento de la totalidad; es algo que está insinuado y no puede ser aprehendido como un desenlace. Para el escritor que ocupa este trabajo no hay condicionamientos ni límites de géneros, ya que en $E l$ laberinto convergen meditación filosófica, ensayo, poesía, y reflexión religiosa. $E l$ laberinto está próximo a los problemas del hombre y es un símbolo de una nueva ruptura, de una nueva vitalidad dentro del género novelístico.

Para concluir, se puede señalar que la noción de concisión y narratividad que ofrece El laberinto de Sión pone a prueba el mundo imaginario del lector y el modo de presentarlo por el escritor. En esta creación mutua, como ya se ha visto, tiene decisiva importancia la estructura narrativa y la participación activa del lector. El autor de Laberinto da, al menos, dos lecturas a su novela, entre otras muchas otras posibles. Esta novela es una imbricación de más de dos proyectos. El propósito superficial atañe más o menos a una apreciación o a un intento del vivir insustancial, trivial y frívolo, y se escucha el diseño reflexivo y penetrante que acusa las enigmáticas vinculaciones del hombre con sus experiencias existenciales. El autor propone ambos proyectos; entonces, el lector es capaz de aprehenderse al mundo quizá por la doble estructura de la experiencia. El lector no necesita eliminar el primer diseño, el superficial, ni quedarse con el segundo, sino que los debe aunar para llegar a una posterior proyección.

Laberinto queda en estado de concepción, de inventiva y de posibilidades infinitas. También realza la postura de quien solo sabe que no sabe nada, contradiciendo todo dogmatismo; solo admite una escritura que confiese su propia inquietud, recelo, y sospecha de ese cambiar durante la experiencia. En Laberinto se 
advierte que la literatura está en constante peligro de dar primacía a los conceptos y perder la inmediatez de las intuiciones, porque según Barnatán, los conceptos, las palabras, no han de ser vistas como celosías sino como ventanas.

Llegado a este punto, se puede concluir que Marcos Ricardo Barnatán expone en su obra una conciencia cosmopolita y que abona el terreno para lograr una repercusión que va mucho más allá de los límites que impone, algunas veces, la razón humana.

\subsection{EL LABERINTO DE SIÓN: UN MUNDO URBANO CARENTE DE LA IDEA DE LO DIVINO}

La fascinación que Marcos Ricardo Barnatán ha tenido por la obra de Gershom Scholem se debe a que en ella ha encontrado la imagen paradigmática del espíritu de nuestra época: la presentación meticulosa de un mundo carente de la idea de lo divino.

La obra de Scholem cuestiona radicalmente el espíritu de la época en la cual la idea de una presencia divina en el mundo había perdido todo sentido. Obsérvese que Marcos Ricardo dedica El laberinto de Sión a Scholem.

Aunque muchos de los personajes de Barnatán vagan por un mundo que no son capaces de descifrar, el lector sensible a la dimensión metafísica latente en Laberinto debe discernir en las repeticiones obsesivas de los temas de duda, en la incertidumbre, en el olvido, así como en la proliferación de formas lingüística de negación y en la desambigüedad, el intento de encontrar un rastro, aunque invertido, de una trascendencia desaparecida.

En una de las charlas que el protagonista mantiene con su abuelo antes de empezar una pequeña fiesta con motivo de la graduación del colegio secundario, este 
deja en claro el profundo dilema presente en ambos personajes separados

generacionalmente: la angustia por la posible pérdida de la tradición religiosa.

Aún no había llegado nadie y aprovechamos para charlar un rato a solas, hablamos de mi futuro y de su pasado. El temía por mi futuro y yo por su pasado. Nos interrumpieron para hacernos probar las empanadillas de queso todavía calientes. "Cualquiera que sea tu destino no debes olvidarme - me dijo - cualquiera que sea. Recordándome a mí, recordarás a tus antepasados y a Su Ley” (Laberinto, 102).

En la literatura judía abundan las indicaciones que denotan la percepción de los problemas generacionales, sin embargo rara vez esta percepción aparece verbalizada. Por lo general el judío del pasado era muy cauto para manifestar su preocupación y su experiencia religiosa personal, lo que muchas veces llevó a confundir reticencia con apatía espiritual.

Bajo la calmada superficie del credo y la ley, las almas siempre han estado activas. La tarea según Laberinto consiste en penetrar bajo la tranquilidad del credo y la tradición para lograr oír los ecos de la lucha y recuperar las intuiciones vivas. Para tal fin el judaísmo propone tres vías: el primer camino es percibir la presencia de Dios en el mundo, en las cosas; el segundo es percibir Su presencia en la Torá, y el tercero es percibir Su presencia en todos los actos.

Estos tres caminos corresponden en la tradición hebrea a los aspectos principales de la existencia religiosa: culto, estudio y acción. Los tres son uno y se deben recorrer todos para llegar al destino único, y eso es lo que descubre un alma religiosa: el Dios de la naturaleza es el Dios de la historia y la manera de conocerlo es hacer su voluntad. De aquí parte a y su vez concluye la severa importancia que tiene para el pueblo hebreo la transmisión de su cultura. Es a través del culto, del estudio y de la acción como se puede deslumbrar la Revelación que, por su esencial y vital importancia, debe ser trasmitida. 
En la novela El laberinto de Sión se publica el problema actual dentro del judaísmo: el peligro de la desaparición de la trascendencia, y en sus mismas páginas ofrece los pasos harto conocidos para solucionarlo. A través del fragmento siguiente se detalla la experiencia humana, la cual posee el potencial de conducirse desde "el peor de los sin sentidos" a la más virtuosa y anhelada experiencia de Revelación. Este segmento de Laberinto es uno de los más dinámicos y merecedores del calificativo de extraordinario.

Accidentes, fracasos, timidez, oscuridad, criaturas imaginarias, soledad, muerte, una terrible enfermedad, el secuestro siempre amenazado, el ejército secreto, las tropas policiacas invisibles. Ellos, los temibles, los terribles, los sádicos, El enemigo, Ellos. Vienen por usted. Huya, Huya. Vienen ya. Golpean la puerta, entran por la ventana, en los corredores se agolpan, instalan las ametralladoras, los grandes focos iluminan las playas, las praderas, el cielo, los techados, es el Fin. Nada puede hacer. Todo acaba. Pero no. Accione el botón. Allí la escalera rápido. Baje, el pasadizo secreto, la luz de una vela. Allí el palacio de cristal, las habitaciones de porcelana azules, el salón violeta, las máquinas del eterno retorno, los fuegos helados, ponga el dedo, no quema, no tenga miedo más allá la eterna montaña rusa y sus ruidos infernales, siga hacia adelante, ya nadie lo sigue, aminore a marcha, doble a la izquierda, los ríos helados, investigue las orillas, mire esa hermosa piedra, cómo brilla es una autentica maravilla. Brilla orilla maravilla. Las tres palabras claves. El conjuro se Alza. Se abren las puertas. Sésamo ábrete. El fin se enlaza con el principio. Vengo del final voy hacia el principio. La luz incendia todo el paisaje. La paz nos ahoga. Un resplandor. Adonai. Adonai. El señor se regocija de recibir a los justos (Laberinto, 130).

Según Barnatán, no es curiosidad histórica lo que despierta el interés por el problema de la Revelación. En cuanto suceso del pasado que con posterioridad afectó el curso de la civilización, la Revelación no atraería el pensamiento moderno de la forma que lo hace. Si le concierne al hombre moderno, no es por el impacto que produjo sobre generaciones, sino como algo que puede o no poseer una pertinencia eterna y sin disminución alguna. Laberinto evoca este concepto no a la sombra de un fenómeno arcaico, sino que intenta examinar y actualizar — si es que cabe este 
concepto en lo concerniente con la divinidad - la eterna pregunta: ¿Debemos creer que existe una voz que llama al hombre en nombre de Dios? "No se trata tan solo de un asunto personal, sino de una cuestión que concierne a todos los hombres desde el comienzo hasta el fin de los días" (Buber, Entre el hombre y el hombre 45).

El protagonista de Laberinto le hace saber al lector, muy al principio de la novela, que nadie que haya experimentado al menos una vez en su vida la aterradora gravedad de la historia humana o la seriedad de la existencia individual puede permitirse ignorar el problema. Debe necesariamente decidir entre el sí o el no.

El más serio obstáculo con el que tropieza el protagonista de Laberinto - y en general el hombre moderno- “al emprender un análisis de la revelación no surge de las dudas que puede abrigar en cuanto a la autenticidad de las experiencias relatadas en los libros sagrados" (Heschel, Dios en busca del hombre 128).

Según Laberinto, aun de ser posible, la vindicación más cabal de tales relatos sería poco pertinente. El problema más serio es la ausencia del problema. Para tener sentido, una respuesta presupone el conocimiento de una pregunta, pero el clima en el que se vive hoy, según Laberinto, no es propicio para el continuo crecimiento de la pregunta que llevó siglos cultivar. La Torá es una respuesta a la pregunta suprema: ¿Qué nos pide Dios? Sin embargo, la pregunta ha desaparecido del mundo. "Se pinta a Dios como una masa de vaguedad oculta detrás de un velo de enigmas y Su voz se ha tornado extranjera para la mente del hombre moderno, para el corazón, y para el alma" (Heschel, Dios en busca del hombre 321). Se ha aprendido escuchar cualquier yo, excepto al Yo de Dios. "El hombre moderno con orgullo puede aclarar que nada animal le es ajeno, sin embargo todo lo divino sí” (Buber, Imágenes del bien y del mal $65)$. 
Tal es la naturaleza de la Torá en la vida moderna que es una respuesta sublime, pero que ya no se conoce la pregunta. A menos que se rescate la pregunta, no hay esperanza de comprender cuál es el plan que tiene Dios para con el hombre, $\mathrm{Su}$ Ley; entonces, carece de sentido para el hombre moderno y solitario, y por tanto la tradición se hace un cuenco vacío y justo es este el hilo que enhebra toda la trama de El laberinto de Sión, la primera novela de Marcos Ricardo Barnatán.

En los escritos de Scholem, Barnatán vio el reflejo de la crisis de tradición que, para él, caracteriza nuestra época y se detecta no solo en las creencias religiosas como tal sino también en el deterioro de los procesos de trasmisión. En Laberinto, el protagonista hace referencias a esta crisis de trasmisión, incluso cuando describe pequeños detalles: "Papá había comido sin hablarnos, inquieto repitió la bendición del pan tan maquinalmente que no me di cuenta de ella" (54). Más adelante, en el texto, explica que fueron su abuelo y el rabino Khaen los primeros en preocuparse por su educación religiosa con el objetivo de combatir "aquel enloquecido miedo nocturno" que el protagonista sufría:

Ya no necesitaba de la luz [de la habitación], la Shemá era suficiente para iluminar y sobrevivir en las tempestades. Aprendí también a besar la mesusá antes de salir de casa y el abuelo me prometió llevarme al templo los días de fiesta grande. [...] Supe así que era parte de un orden, de un Gran Orden que no había nacido conmigo, sino que existía desde siempre y que sería eterno (Laberinto, 56).

Barnatán valora la importancia primordial de la trasmisión oral para la perpetuación de una cultura. En la tradición judía, aunque el principio es aplicable a todas las culturas, los textos son interpretados, reinterpretados, y re-actualizados constantemente. Lo que sucedió en Europa fue que los responsables de hacer estas actualizaciones dentro del cristianismo fueron las iglesias y las universidades; sin 
embargo, la diáspora judía nunca contó con ningún tipo de institución que se encargara de tan necesario asunto.

Más bien la tradición se transmitió en el espacio privado de la casa de estudio, de la oración en el entorno familiar, en el encuentro cara a cara, en la intimidad de la familia, a través de la relación entre padre e hijo. El protagonista recuerda los primeros momentos con los libros sagrados de siguiente manera:

Tía Luna me había mostrado aquel pesado libro que el abuelo guardaba con sumo cuidado en un armario del gran salón. Tenía cinco años [...]. Me resultaba muy difícil sostener el libro. Creo recordar sus gruesas pastas azules estampadas en oro. Tía Luna comprendía mi debilidad ayudándome sigilosamente para evitar en mí un vergonzoso sentimiento de impotencia. [...] Entonces era solo un catálogo de letras desconocidas páginas de extraños signos contorsionados y extremadamente negros. Los miraba uno a uno maravillado en aquel laberinto indescifrable pero sin embargo profundamente amado. Algo me decía ya que era El gran Libro, el mítico receptáculo de todos los libros. [...] (Laberinto, 57).

Mientras que la crisis de fe de la religión cristiana en Europa había comenzado durante el Renacimiento, esencialmente, con una reevaluación de los conceptos críticos dentro del cuerpo religioso mismo, el judaísmo europeo, en cambio, "ha sufrido esta crisis desde la Emancipación, donde las estructuras tradicionales sociales se quebraron y la autoridad paternal" (Brod, Kafka 81), entre otros, se debilitaron, provocando que se pusiera en peligro la transmisión de los textos revelados. Sin embargo, lo que se puso en realidad en peligro aquí — señala Barnatán— "no fue la validez del contenido de la creencia misma sino el proceso de trasmisión" (Robert, Kafka 13). Aquí el enfermizo y frágil protagonista de Laberinto describe la irrisoria forma en que su tía Luna se refiere a él, como elemento clave por estar "doblemente entroncado con el legendario apellido que ella mantiene celosamente".

A tía Luna le gusta decir a mis amigos que yo estoy doblemente entroncado con el legendario apellido que ella mantiene celosamente. Es importante hijo mío ser de la hermana elegida por el destino para 
unirse a un hombre que ostenta entre los suyos aquel místico nombre que aprendió a pronunciar con religiosa veneración desde el día que despertó a la vida. Para tía Luna yo soy doblemente parte de su sangre, de esa sempiterna pureza que proviene de la lejana Allepo y que ha permanecido intacta con sus ritos y sus altares con todos sus fabulosos signos y señales secretas desde el instante en que abandono el paraíso peninsular de Sefarad.

Los ojos de tía Luna suelen brillar con la misma luz que yo había notado en ella en mi niñez. Es el luminoso haz de las tardes de lectura del Gran Libro. En mi recuerdo tía Luna, maravillosamente inocente y separada del resto de los humanos por una barrera invisible de espuma, vive un romance con el pasado mágico, al que me enseño a amar. Bajo su lógica aparente hay un rostro secreto, un misticismo extraño que solo puede revelarse a algunos elegidos (Laberinto, 60)

El protagonista de esta novela tiene un enraizado y fuerte apellido, según su tía Luna, lo que no combina con la delicada salud del que lo ostenta. Este hecho es algo llamativo, y además es recurrente en toda la novela. Incluso algunas veces puede hacer sospechar al lector que de lo que realmente se está tratando es del mismo cuerpo religioso y de su mecanismo de trasmisión.

Es evidente que "la entrada de los judíos occidentales en el mundo moderno, coincidió, en gran medida, con el abandono del judaísmo tradicional. Esta dejadez con frecuencia venía de una conciencia de rechazo a las normas y a los valores antiguos" (Blanchot, De Kafka a Kafka 99) y tuvo el efecto de un ataque irreversible a la memoria colectiva.

Esta perturbación del proceso de trasmisión es inseparable, en el judaísmo XIX y XX, con el desorden intelectual en la generación de los hijos. La rebelión de los hijos contra los padres fue experimentado en las familias judías "como un debate ideológico fundamentalmente, sobre la validez de las normas de la vida tradicional y el pensamiento" (Trebolle, El judaísmo moderno 16). El hijo rebelde ya es un tema banal en la literatura de principios del siglo XX y había tomado en el microcosmos de las familias judías las dimensiones de un verdadero revés de valores. Por ejemplo, en 
la carta que Franz Kafka le escribe a su padre, señala las ambigüedades del padre hacia su propia condición de judío y las contradicciones ${ }^{100}$ de una demanda por el padre, y de un mantenimiento de la fidelidad hacia valores que este no le ha sabido trasmitir por el hijo. Esto hace que se despoje el discurso del padre de cualquier tipo de credibilidad. Esta doble ligadura entre padre e hijo y viceversa refleja las incertidumbres de una generación de transición que se desgarra entre su vínculo con el pasado y su trazo hacia la asimilación, donde la autoridad paterna queda irremediablemente replegada y desvalorizada. Laberinto lo que hace es advertir sobre este accidente dentro de la comunidad judía.

En el judaísmo, la permanencia de la tradición se basa precisamente en la fuerza intangible de esta autoridad que garantiza la autenticidad y la validez, siempre presente, de la Ley divina. Esta es la razón por la que en la crítica freudiana de la religión, Freud base su desmitificación de la idea de Dios. Él concibe a Éste como una proyección de la imagen del padre y en lo que respecta a la Ley; Freud la conceptuó como una invención de las órdenes paternas.

En El laberinto de Sión el tema central es la trasmisión de la Ley. En los recordatorios, cartas, memorias, monólogos y diálogos que en ocasiones el protagonista saca del baúl de los recuerdos, hay una constante: un ajuste de cuentas severo con la imagen familiar pero, sobre todo, con la figura del padre. En Laberinto la figura del padre del protagonista es débil. No es el que juega un papel importante en la educación religiosa del que era, en aquel entonces, un niño. La figura del padre se hace borrosa, no es capaz ni de determinar a qué edad su hijo debe comenzar el

\footnotetext{
${ }^{100}$ Véase Carta a su padre de Franz Kafka. "Más tarde, cuando adolescente, no comprendía como tu nada de judaísmo de que disponías era capaz de echarme en cara que yo, por "piedad" según tu expresión, no me esforzaba por practicar una nada similar. Era un efecto, hasta donde yo alcanzaba a ver, una nada, una broma, ni siquiera una broma" (31).
} 
colegio: "Tenía cinco años, pero a pesar de los esfuerzos de mi padre aún no concurría al colegio. Todos temían por mi salud delicada y preferían enseñarme en casa las primeras letras" (56-57). El padre del protagonista es un tipo de personaje enajenado, apático y débil de carácter, quien actúa motivado por un "no contradecir la reglas”, pero para él la tradición no tiene ningún sentido. En toda la novela hay un interés marcado en demostrar que las personas cercanas al protagonista - exceptuando la figura del padre — son las que asumen el papel de la educación paterna. La madre delega en Max y el padre en la tía Luna. Sin embargo en muchos de estos círculos donde se desenvuelven el protagonista y los encargados de su educación, como su tía Luna y el profesor Max, la Ley no era más que un contenedor desprovisto del sentido último.

Acaso no sea que una pesadilla, todos nosotros, enfrentados a la rugosidad de la piedra, al terciopelo helado que abre infinito, a la necesidad del grito que nos será devuelto exacto, tan gris como al principio. Nadie podrá convencerme, la realidad se alarga y se enreda, se pierde y nos despoja, pero nunca adopta la forma equívoca de un fantasma. Y el principio que nunca comenzó corre a la búsqueda de un final inacabado (Laberinto 138).

Por muchas generaciones, el único contenido de la Ley era su propia legalidad y esta expresaba no más que su autoridad, pero no significaba nada, no se encontraba en ella ningún orden simbólico de importancia. Su única función era la de ser un signo: el signo de la identidad judía.

Scholem, a quien Barnatán le dedica El laberinto de Sión, pertenece a la generación de los hijos perdidos rebeldes, cuya única herencia de los padres era el mantenimiento de permanecer fieles a una identidad vacía de todo contenido. Puede ser esta la causa de su atracción por los escritos de G. Scholem. En el corazón de la obra de Barnatán, como una interrogación incesante, se detecta la cuestión de la Ley. Se trata de una cuestión relativa a la naturaleza de la Ley o al significado de esta; que 
en su lugar -0 , preferiblemente, en su no lugar - hay un vuelo o una retirada de principios que pretenden ser absolutos, sin tener que revelar la fuente de su autoridad. 


\section{CONCLUSIONES}

Lo que hace que Barnatán no pertenezca al boom es que él no busca un metadiscurso para vigorizar la identidad latinoamericana. Los artistas del boom son producto de las nuevas expectativas revolucionarias, mientras que los novísimos quedan vinculados al periodo de las desilusiones con los proyectos de democratización, y por último, los kabalistas se asocian a la anhelada búsqueda de la solución de la necesidad y la urgencia de la humanidad por alcanzar la paz y la alegría, y este proceso abarca toda la existencia humana. Barnatán pertenece al grupo de los poetas novísimos ${ }^{101}$, pero con la mirada puesta en la perspectiva religiosa judía.

Después de la muerte de Franco, los novísimos ${ }^{102}$ son el grupo reinante en lo que a poesía se refiere. Pasados los años, todos los poetas que estaban enmarcados bajo ese rótulo comienzan a buscar una línea más personal. Es el caso de Marcos Ricardo Barnatán, en cuya colección de poemas atenúa ese culturalismo asfixiante que predomina en su obra narrativa. Sin embargo, en ambos géneros sigue presente el metadiscurso y un gran interés por la poesía experimental verbal. Barnatán, tal vez inconscientemente, va al mismo ritmo que los poetas y escritores latinoamericanos.

La poesía de Barnatán se caracteriza por su tono coloquial e íntimo. Su sintaxis es compleja y su métrica es elaborada, y esto hace posible que la densidad y la concentración expresiva sea una constante en su obra. La temática que aborda en la mayoría de sus trabajos se refiere a la desolación que vive el hombre contemporáneo, al cual ofrece, en su obra, una esperanza.

\footnotetext{
${ }^{101}$ Véase para más referencias Nueve novísimos poetas españoles de José María Castellet.

${ }^{102}$ Véase La poesía postmoderna de los novísimos: una nueva postura ante la realidad y el arte, de Andrew P. Debicki, y Claves de la actual rehumanización poética, de Antonio Sánchez Zamarreño.
} 
Para Barnatán, el poder de la voz poética radica en hablarle al hombre de acuerdo con la agudeza ${ }^{103}$ y la sagacidad que tenga. Y la maravilla de su discurso consiste en ramificarse en setenta y siete voces, en setenta idiomas, para que todos los hombres participen de su creación literaria, porque para Barnatán decir lo obvio aún no es decir la verdad, que en palabras del rabino Mendel de Kotsk sería: "Cuando lo obvio y la Palabra se hallan en conflicto, la verdad es la negativa a darse por satisfecho con la apariencia de los hechos. La verdad es el coraje de ahondar en los hechos a fin de descubrir cómo se relacionan con las Palabras" (A Biographical Study of the Chasidic Master, 128).

Ya en la poesía de Barnatán no hay limitación del concepto de forma ${ }^{104}$, a lo que la crítica suele llamar características formales —o sea, la disposición artística de la materia sensible_-, ni tampoco la reducción de forma a la idea de continente como contraparte del contenido. La forma del poemario El oráculo invocado no puede ser otra que la organización de su ser en una entidad. Tener forma es tener validez de individuo, de cosa individualizable, conocible y reconocible mediante ciertos rasgos caracterizadores que le marcan una fisonomía propia. En su voluntad de estilo, Barnatán estima primero como ideal poético la ausencia de forma ${ }^{105}$, ya que para él lo que nos llega del mundo y lo que sale ya procesado del hombre deben manifestarse tal como vienen, como materia, sin reducirse ${ }^{106}$ a fisonomías.

\footnotetext{
${ }^{103}$ Compárese Aristóteles, De Mundo 391: “mediante el ojo divino del alma aprehendiendo las cosas divinas e interpretándolas para la humanidad". También véase The Duties of the Heart, de Jeshbon Hanefesh, capítulo 3, que se refiere a la ciencia interior a la que describe como la luz de los corazones y el esplendor de las almas. Por su parte, la Escritura dice: "he aquí que deseas la verdad en lo íntimo; enséñame, pues, a conocer la sabiduría en lo íntimo de mi corazón” (Salmos 51: 8).

${ }^{105}$ Véase Louis Ginsberg, The legends of the Jews, Vol. I, p. 44 y Vol. V, p. 60.

${ }^{106}$ Compárese Maimónides, Guía de los perplejos, Vol. II, cap. 25.
} 
Barnatán, poeta creador, opina que lo racional es inevitable en la obra, porque la palabra es instrumento de la poesía y tiene un esqueleto de razón; es por eso que él se ve obligado a incluir elementos que no funcionan estructuralmente. Barnatán lucha con lo racional por ser enemigo de lo poético, y no puede dejar de luchar porque, aunque lo reduzca a polvo, ahí anda el polvo reclamando su lugar de atención. Es una verdadera lucha — dice Barnatán — con peripecias y no mera tarea de demolición, donde a veces se pacta con el enemigo, y a veces, este sirve de trampolín.

Llegados a este punto, se puede advertir que Marcos Ricardo Barnatán queda inscrito culturalmente en las tendencias artísticas de su tiempo. Su actitud polémica tiene raíz fuera de su profesión de escribir: la raíz se encuentra en la naturaleza misma de la vida social e individual de nuestros días. Barnatán, entonces, reniega de las formas heredadas, vuelve su mirada al caos de las fuerzas primigenias del alma y se entrega a la aventura artística, donde en la mística judía encuentra su pilar más fuerte. Este poeta lleva con dignidad y plenitud de sentido la representación de nuestro tiempo, ya que muestra en su obra, en general, una íntima coherencia e identidad de fondo, las grietas y desmoronamientos formales, las rupturas con la tradición, las imágenes como relámpagos superpuestos y truncados y la omnipresencia de la angustia metafísica. Es la contextura misma de nuestra época desquiciada resonando entera en los versos del poeta, que al principio no parecía tener otra justificación que la arbitrariedad individual.

Barnatán, tal pareciera, es un individuo muy original; sin embargo, si se le estudia bien, resulta lo más representativo de la vida circundante, no en lo contingente, sino en lo esencial. No hay en él estilo, ni pensamiento ${ }^{107}$ individual, ni personalidad poderosa que no incluya en su constitución misma el hablar común de

${ }^{107}$ Compárese The Mishnah of Rabbi Eliezer, regla 14. Nueva York: Enelow, 1933, p 25. 
sus prójimos en el idioma, el curso de las ideas reinantes, la condición histórica y cultural de su pueblo y de su tiempo.

\section{LA LITERATURA COMO PRÁTICA DE LA LIBERTAD EN LA OBRA DE MARCOS RICARDO BARNATÁN}

No siempre se puede considerar una persona libre a aquella cuyas conductas están bajo el dominio de su propia voluntad, ya que esta última no es una categoría última ni se encuentra finiquitada ni aislada, sino que está determinada en sus fundamentos por caracteres que se desvanecen de su control, tal y como lo declara la voz poética del poema Tiresias: "Yo que respondí a todas las crueles/Inquisiciones y hablé de las guerras/ Incesantes y de la muerte" (5-7). Tampoco es libre quien es lo que quiere ser, ya que lo que una persona quiere ser se halla determinado por factores exteriores a ella. ¿Cómo es posible, entonces, la libertad personal?

La naturaleza de esa libertad es un misterio y la formidable acumulación de pruebas a favor del determinismo hace que resulte muy difícil creer en la libertad; sin embargo, sin esta creencia, la vida moral carece de significado. Según Abraham J. Heschel, "sin tomar en serio a la libertad, es imposible tomar en serio al ser humano desde la óptica del naturalismo: la libertad humana es una ilusión. Si todos los hechos del universo físico, y por tanto también los de la historia humana, dependen de causas y están condicionados por estas, entonces el hombre es un prisionero de las circunstancias" (523). No puede haber en la vida momentos libres, creativos, ya que ellos presupondrían un vacío en el tiempo o una ruptura en la serie de causa y efecto.

El hombre vive encadenado a su ambiente natural, a la sociedad y a su propio carácter; es esclavo de necesidades, intereses y deseos egoístas. Ser libre en cambio 
implica trascender la naturaleza, la sociedad, el carácter, las necesidades, los intereses, los deseos. ¿Cómo, entonces, es concebible la libertad ${ }^{108}$ ?

La realidad de la libertad, de la facultad de pensar $^{109}$, de querer o de tomar decisiones más allá de la casualidad fisiológica y psicológica solo es concebible si se parte de que la vida humana entraña a la vez proceso y suceso. Si el hombre es visto como un proceso, si sus futuras determinaciones se consideran calculables, es preciso entonces negar la libertad. Ella — la libertad ${ }^{110}$ — significa que el hombre es capaz de expresarse en sucesos que están más allá de su propia inmersión en los procesos naturales del vivir.

Creer en la libertad es creer en los sucesos, es sostener que el hombre puede eludir las ataduras de los procesos en los que se encuentra inmerso y actuar de manera no requerida por factores previos. La libertad es el estado en el que la persona sale de su yo por instantes; es un estado de éxtasis espiritual en el sentido original del término. La voz poética de Puertas en el muro del poeta Marcos Ricardo Barnatán recrea excelentemente este concepto:

Despertar de nuestro sueño profundo, un minuto de vigilia, un instante frente a la antigua sabiduría que mana de los mágicos alfabetos. Se abrían los abismos al borde del alba, en medio del camino se levantaban, cercas de fuego, tristeza muda que cautiva el alma. Un jardín velado rodea Arcadia, se oyen himnos terribles ya olvidados. Estrechas son las puertas en el muro, inmenso eterno el todo que se esfuma cuando volvemos a la embriaguez celeste del origen.

"Estrechas son las puertas” (7) dice la voz poética, ¿Quién, entonces, es exento, emancipado o soberano? El hombre ingenioso e imaginativo al que no impulsan los

\footnotetext{
${ }^{109}$ Buber, M. On judaísmo. Nueva York: Schocken Books, 1967, p. 67.

${ }^{110}$ Véase, en El humanismo hebreo de Martin Buber, de Carlos Díaz, el capítulo "La luz que hay en el eclipse".
} 
torbellinos de la necesidad, que no está sujetado a los procesos, que no es cautivo de los acontecimientos. La libertad es un acto y ocurre; no es un estado constante en el hombre, y así lo manifiestan los dos primeros versos del poema.

La libertad no supone ni equivale a vivir como se desea y place, sino que entraña una capacidad para vivir espiritualmente, para elevarse a una dimensión más encumbrada de existencia. La libertad no es, como muchos intentan explicar, un principio de incertidumbre, la capacidad de proceder sin pretexto ni motivos. Esta noción puede desorientar y desconcertar, ya que confunde la libertad con el caos; el libre albedrío con la arbitrariedad de un acto de voluntad inmotivada.

La libertad tampoco es la oportunidad de optar entre variadas motivaciones. Según Martin Buber, "la libertad incluye el acto de elegir, pero su raíz se halla en la comprensión de que el yo no es soberano" (67). La libertad es un suceso espiritual, es un acto de compromiso del espíritu.

El problema básico de la libertad, según la filosofía de Marcos Ricardo Barnatán, consiste en saber cómo podemos estar seguros de que los supuestos sucesos no son aspectos enmascarados de un proceso, o de que los actos creativos no son generados por evoluciones naturales de las que no tenemos conocimientos. La idea de las posibilidades creativas y "la posibilidad de vivir espiritualmente dependen de la concepción de que la creación y el hombre son algo más que un producto de la naturaleza" (Buber, Sobre el judaísmo, 89).

Es interesante señalar que el concepto último de la filosofía ${ }^{111}$ griega es la idea de Cosmos, de orden; sin embargo, la primera enseñanza de la Torá es la idea de

\footnotetext{
${ }^{111}$ Las categorías en las que el hombre bíblico concebía a Dios, al hombre, y al mundo son tan diferentes de los supuestos de la metafísica sobre los cuales se basa la mayor parte de la filosofía occidental, que ciertas intuiciones significativas para la mentalidad bíblica al parecer carecen de sentido para la mentalidad griega. Sería un logro de primera magnitud reconstruir la naturaleza peculiar del pensamiento bíblico y elucidar su divergencia con otro tipo de pensamiento. Ello abriría nuevas
} 
Creación. Traducidos a principios eternos, Cosmos significa destino, en tanto que Creación significa libertad.

El significado esencial de la creación no es que el Universo fue creado en un momento determinado del tiempo. El significado esencial de la Creación no surgió por necesidad sino como resultado de la libertad. El hombre es libre de actuar o de perder la libertad. Al elegir el mal, renuncia a su apego al espíritu y se priva de la oportunidad de dejar que la libertad suceda. Así, podemos ser libres al emplear o ignorar la libertad; no somos libres en cuanto a la posesión de la libertad. Somos libres de elegir entre el mal y el bien; no somos libres en cuanto a tener que elegir. De hecho estamos obligados a elegir. Por lo tanto, toda libertad es una situación en la que Dios espera que el hombre elija.

En el pensamiento judío, el problema del ser nunca puede tratarse aislado sino solo en relación con Dios. El orden o la necesidad no son una categoría última sino un aspecto del atributo dinámico del juicio divino. El pensamiento judío afirma, además, que el ser está creado y mantenido no solo por la necesidad, sino también por la libertad, por la preocupación libre y personal de Dios por el ser.

Después de leer la obra de Barnatán cabe preguntar: ¿qué es el hombre para que Dios se preocupe por él? Y debemos seguir recordando que es precisamente la solicitud de Dios por el hombre la que constituye la grandeza de este. Ser es significar y lo que el hombre significa es el gran misterio de ser socio de Dios, señala el poeta.

¿Es posible creer que lo eterno puede preocuparse por lo trivial? La verdad es que nada es trivial; lo que a nuestros ojos es pequeño es infinitamente grande a los ojos del Dios infinito. Porque lo infinito nunca está aislado: se halla entretejido de reflexión filosófica en su conjunto. El pensamiento bíblico puede contribuir en medida importante a plasmar nuestra visión filosófica del mundo. 
innumerables maneras con el curso de los sucesos infinitos y cuanto más prominente sea el nivel de conciencia espiritual, mayor será la sensibilidad hacia los demás y la preocupación por ellos.

El presente trabajo ha querido demostrar que la Torá y sus comentarios, así como también el nuevo discurso de Marcos Ricardo Barnatán, no intentan el levantamiento de un personaje protagonista al modo acostumbrado, sino que pretenden que el lector asista a otorgar la dimensión completa de las criaturas que merodean por la Obra u obra. Para que se pueda convertir un ser plano en uno de tercera dimensión, también se cuenta con la fuerza del lector - intérprete con todas sus experiencias y destrezas, pero también con todas las debilidades y restricciones.

Barnatán muestra, como se ha visto hasta aquí, una nueva forma de advertir el mundo, de husmearlo, de enunciarlo, de presagiarlo, y es porque establece una detallada geografía del itinerario hacia los espacios con los que el ser humano sueña. Marcos Ricardo Barnatán muestra una enorme devoción por el discurso, y por el tratamiento del lenguaje y esta característica de ellos los hace tener algo en común con los kabalistas de Provenza, como se ha visto hasta aquí.

Marcos Ricardo Barnatán, al igual que los tres libros místicos básicos del judaísmo, crea un sorprendente andamiaje expresivo sin atadura a modelos establecidos. Esta estructura expresiva erigida por una vasta red de símbolos se alimenta de la reivindicación de la libertad.

La pregunta evaluativa y a modo de conclusión que surge es si puede la obra de Marcos Ricardo Barnatán ser una adición a los comentarios kabalísticos. La respuesta es que su obra está demasiado alejada del torrente judaico para poder pertenecer a él. 
Su obra descansa fuera de las preocupaciones que unen a los kabalistas con la línea dominante y central del judaísmo: el estudio de la Torá y sus comentarios, la observación de sus Leyes y el interés por la lengua hebrea.

Ahora pudiera hacerse otra pregunta: si la obra de Barnatán no puede contar como un comentario kabalístico, ¿qué relación, entonces, tiene ésta con el sistema místico judío?

El trabajo pertenece, claramente, a una escritura moderna. Diseñada para un lector que entiende las técnicas experimentales, que puede ensamblar fragmentos de textos y aceptar una inestabilidad tiempo-espacio. Este lector tiene mucho en común con los lectores de los libros de sabiduría hermética judía ya que el lector moderno tiene la experiencia de buscar las correspondencias ocultas y de ahí construir una unidad.

La obra de Marcos Ricardo Barnatán lleva al lector por los caminos de la búsqueda y no le ofrece un conjunto de información fiable acerca de la Kábala sino que le ofrece como conocimiento oculto, una conciencia sobre el valor especial de la mística desarrollada por la cultura judía durante la Edad Media. 


\section{BIBLIOGRAFÍA}

Aizenberg, Edna. Boooks and Bombs in Buenos Aires. Hanover: University of New England, 2002. Print.

---. Borges, El tejedor del aleph y otros ensayos: del hebraísmo al poscolonialismo. Madrid: Vervuert, 1997. Print.

Alonso, Amado. Poesía y estilo de Pablo Neruda. Buenos Aires: Sudamérica, 1968. Print.

Amorós, Amparo. Los novísimos y cierra España. Madrid: Ínsula, 1989. Print.

Anderson, Perry. Los orígenes de la postmodernidad. Barcelona: Anagrama, 1998. Print.

Antología del rabi Israel: Baal Shem Tov. Argentina: Bnei Sholem, 1993. Print.

Aviezer, Nathan. En el principio: creación bíblica y ciencia. Trans. David L. Brabon. 1st ed. Caracas: KTAV, 1997. Print.

Barnatán, Marcos Ricardo. El oráculo invocado. Madrid: Visor Libros, 1984. Print.

---. "A donde el brazo te lleve: la muerte de Kenneth Noland." El Mundo [Madrid] 11 Jan. 2010. Print.

---. Antología del Zohar: lecturas básicas de la Kábala. 5th ed. Madrid: Edaf, 2007. Print.

---. Borges, biografía total. Madrid: Temas de hoy, 1995. Print.

---. Consulado general, 2001. Barcelona: Tusquets, 2001. Print.

---. El laberinto de Sión. Madrid: Anjana, 1986. Print.

---. Jorge Luis Borges. 2nd ed. Madrid: Júcar, 1976. Print.

---. La Kábala: una mística del lenguaje. 1st ed. Barcelona: Barral, 1974. Print.

---. Los pasos perdidos. Madrid: Ediciones Rialp, S.A, 1968. Print.

---. "Reseñas de reseñas: el rabino no cree en Dios." Raíces: revista judía de cultura Invierno 1998: 46. Print.

---. "Siete enigmas de Abraham Bar Nathan de Luniel." Raíces: revista judía de cultura Verano 1998: 25-29. Print.

Barrylko, Jaime. Filosofía judía. Bogotá: B'nai B'rith, 1976. Print.

---. "El miedo a los hijos." Raíces: revista judía de cultura Apr. 1993: 40-42. Print. 
Barthes, Roland. Variaciones sobre la escritura. Barcelona: Paidós, 2002. Print.

Beinart, Haim. "Dos obras en la historiografía judía." Carta de Jerusalén (1993): 3-6. Print.

Benharroch Benmergui, Isaac. "Los judíos vistos por el pensamiento español." Coloquio (1993): 38-46. Print.

Bergstein, Mauricio. "Encuentro de Lacan con la tradición judía." Coloquio (1993): 122-27. Print.

Bibliowicz, Azriel. El rumor del astracán. 3rd ed. Bogotá: Planeta, 1992. Print.

Bloom, Harold. Deconstruction and Criticism. London: Continuum, 2004. Print.

---. Figures of Capable Imagination. New York: Seabury, 1976. Print.

---. Kabbalah and Criticism. New York: Seabury, 1975. Print.

---. Los vasos rotos. México, D.F: Fondo de cultura económica, 1986. Print.

---. Ruin the Sacred Truths: Poetry and Belief from the Bible to the Present. Cambridge, MA: Harvard UP, 1984. Print.

---. The Anxiety of Influence: a Theory of Poetry. New York: Oxford UP, 1997. Print.

Borges, Jorge Luis. El hacedor. Barcelona: Alianza, 1960. Print.

Borges, Jorge Luis. Narraciones. Ed. Marcos Ricardo Barnatán. Madrid: Cátedra, 2006. Print.

Bousoño, Carlos. El irracionalismo poético. Madrid: Gredos, 1977. Print.

Brown, Kenneth. "Poesía en Amsterdam." Carta de Jerusalén (1993): 59-63. Print.

Calderón de la Barca, Pedro. Autos sacramentales completos. Pamplona: Reichenberger, 2005. Google Books. Google. Web. Aug. 2009.

Carpentier, Alejo. El reino de este mundo. 1st ed. Puerto Rico: Universidad de Puerto Rico, 1994. Print.

Castellet, Joseph María. Nueve novísimos españoles. Barcelona: Barral, 1970. Print.

Cecilia, Amparo Alba. "Los cabalistas castellanos (2 Parte). Moisés de León y el Zohar." Raíces: revista judía de cultura Otoño 2006: 65-68. Print.

---. "Los cabalistas castellanos (1 Parte)." Raíces: Revista judía de cultura Verano 2006: 75-82. Print. 
Conrad, Joseph. La flecha de oro. Barcelona: Alba, 2005. Print.

Cortázar, Julio. Rayuela. 2nd ed. Madrid: Cátedra, 2006. Print.

Davids, Leo. "Educación judía familiar: Un tema vital." Coloquio (1993): 103-06. Print.

Díaz, Carlos. El humanismo hebreo de Martín Buber. Salamanca: 2004. Print.

Díaz-Mas, Paloma. "El viaje de Isaac Papo: Hacia un rescate de la memoria histórica sefardí." Raíces: revista judía de cultura Spring 2007: 79-83. Print.

De Sager, Nejama Lapidus, trans. Los cuentos del rabí Najmán. Jerusalem - New York: Breslov Research Institute, 1999. Print.

Del Río, Carmen M. Jorge Luis Borges y la ficción: el conocimiento como invención. Miami: Universal, 1983. Print.

Del Toro, Alfonso. Cartografías y estrategias de la 'postmodernidad' y la 'postcolonialidad' en Latinoamérica. Madrid: Iberoamericana Vervuert, 2006. Print.

Dujovne, León, trans. Kabbala Séfer Yetsirá. Buenos Aires: Signal, 1992. Print.

Eldar, Israel. "Diálogo de educadores israelíes con Gershom Scholem." Carta de Jerusalén (1993): 95-101. Print.

Faingold, Eduardo D. Diáspora y exilio: Crónica de una familia argentina. Buenos Aires: Al margen, 2006. Print.

Fine, Rut. "El lector llamado a ser detective." Carta de Jerusalén (1993): 113-15. Print.

Flames in the Ashes. Dir. Monia Avrehami. Ergo Medica, 1886. Videocassette.

Flores, Ángel. Expliquémonos a Borges como poeta. Ciudad De México: Siglo XXI, 1984. Print.

Fox, Joseph. Rabbi Menachem Mendel of Kotzk: A Biographical Study of the Chasidic Master. New York: Bash, 1988. Print.

Freeman, Tzvi. Trayendo el cielo a la tierra. Trans. Nomi Polichenco de Freeman and Reuven Sigal. 2nd ed. Bueno Aires: Keter Torá, 2005. Print.

García Márquez, Gabriel. La increíble y triste historia de Cádida Eréndida y de su abuela desalmada. Bogotá: Norma, 2005. Print. 
García- Posada, Miguel. 40 Años de poesía española. Madrid: Cincel - Kapelusz, 1979. Print.

Guberman-Pfeffer, Jason. "La solución final." Jabad Magazine: Chabad Friends of Cuban Jewry Summer 2009: 20-21. Print.

Hassán, Iacob M. "Los sefarditas como tópico." Raíces: revista judía de cultura Verano 2006: 41-48. Print.

Hendel, Friedrich. Enciclopedia de las ciencias filosóficas: lógica, naturaleza y espíritu. México, D.F: Porrúa, 1990. Print.

Heschel, Abraham Joshua. Dios en busca del hombre. Buenos Aires: Seminario rabínico latinoamericano, 1984. Print.

Hierro, José. Cuanto sé de mí. Barcelona: Seix Barral, 1974. Print.

Hoffman, Edward. "Maimónides holísticos." Raíces: revista judía de cultura Apr. 1993: 36-38. Print.

Huberman, Ariana, y Alejandro Meter. Memoria y representación: configuraciones culturales y literarias en el imaginario judío latinoamericano. Buenos Aires: Viterbo, 2006. Print.

Idel, Moshe. Absorbing Perfections: Kabbalah and Interpretation. New Haven (Conn.): Yale UP, 2002. Print.

---. Ben: Filiación y misticismo judío. Madrid: Plaza, 2008. Print.

---. Cábala hebrea y cábala cristiana. Buenos Aires: Plaza, 2010. Print.

---. Cábala: nuevas perspectivas. Madrid: Plaza, 2005. Print.

---. Kabbalah: New Perspectives. New Haven, CT: Yale UP, 1988. Print.

---. Old Worlds, New Mirrors: on Jewish Mysticism and Twentieth-century Thought. Philadelphia: University of Pennsylvania, 2010. Print.

Ingenieros, José. "La cultura filosófica en España: La cultura judía." Sefardita (1992): 137-45. Print.

Juan - Navarro, Santiago. Postmodernismo y metaficción histórica una perspectiva interamericana. Valencia: Valencia Universitat, 2002. Print.

---. "Un tal Morelli: teoría y práctica de la lectura en Rayuela, de Julio Cortázar." Revista canadiense de estudios hispánicos Winter 1992: 235-52. Print.

Kafka, Franz. El proceso. 5th ed. Madrid: Cátedra, 2001. Print. 
---. Letter to His Father. New York: Schocken, 1966. Print.

Kann, Nitsa. "Kabbaliterature - Post/Modern Hebrew Literature and Its Kabbalistic Precursors." Diss. University of California, 2006. Print.

Kaplan, Josef. "La vía del judaísmo español occidental a la modernidad." Carta de Jerusalén (1993): 67-77. Print.

Kliksberg, Bernardo. "El judaísmo latinoamericano a finales del siglo XX." Coloquio (1993): 10-38. Print.

Knight, Gareth. Guía práctica: simbolismo cabalístico. Madrid: Equipo difusor del libro, 2006. Print.

Kohan, Horacio. "Puesta en valor del patrimonio cultural judío." Raíces: revista judía de cultura Invierno 2006: 30-39. Print.

Kozer, José. "Llenar la máscara con las ropas del lenguaje." Revista iberoamericana LXVI (2000): 347-66. Print.

---. "Mi padre, judío polvoriento." Raíces: revista judía de cultura Invierno 2006: 5556. Print.

Kramer, Jaim, and Abraham Sutton. Anatomía del alma. Trans. Guillermo Beilinson. 1st ed. Jerusalem: Breslov Research Institute, 2002. Print.

Kristeva, Julia. Al comienzo era amor: psicoanálisis y fe. 1st ed. Barcelona: Gedisa, 1996. Print.

---. Lo femenino y lo sagrado. 1st ed. Madrid: Cátedra, 2000. Print.

Leibowitz, Nejama. Reflexiones sobre la Parasha. Trans. Moshe Krasnikier, Shalom Rosenberg, and Moshe Halevi. [Jerusalem]: [?], [2009]. Print.

León Portilla, Miguel. "Mesoamérica 1492 y la víspera de 1992." Carta de Jerusalén (1993): 7-10. Print.

Levi, Rab Yehuda, trans. Tehilim Et Ratzón: Comentarios, leyes, costumbres, y plegarias para ocasiones especiales. Jerusalem: Feldheim, 2008. Print.

Lindstrom, Naomi. Jewish Issues in Argentine Literature from Gerchunoff to Szichman. Missouri: University of Missouri, 1989. Print.

Lituak, Daniel, trans. Shulján Hamelej. Comp. Shmuel Laniado. Vol. 1, 2,3. Jerusalém: Hakeav, 1990. Print.

Litvin, Jay. "¿Quién tiene que levantar la nota?" Jabad Magazine: Chabad Friends of Cuban Jewry Summer 2009: 36-38. Print. 
Lorch, Netanel. "Jerusalén y el pueblo judío." Carta De Jerusalén (1993): 91-94. Print.

Lotersztein, Salo. "Recordando con humor: los hermanos Marx." Raíces: Revista Judía De Cultura Summer 1993: 20-24. Print.

Loveluck, Juan. La novela hispanoamericana. 3rd ed. Madrid: Universitaria, 1969. Print.

---. Novelistas hispanoamericanos de hoy. Madrid: Taurus, 1976. Print.

Lyon, David. Postmodernidad. Madrid: Alianza, 1996. Print.

---. Postmodernidad. 2nd ed. Madrid: Alianza, 1996. Print.

M, J. "Un Tania para el profesor Wheeler." Jabad Magazine: Chabad Friends of Cuban Jewry Winter 2005: 16-17. Print.

Madirolas, Eduardo. El camino de árbol de la vida. Vol. 1,2. Madrid: Equipo Difusor Del Libro, 2005. Print.

Maimónides. La guía de los perplejos. Biblioteca Virtual Hispánica. PDF.

Martín Ortega, Elisa. "Cábala y poesía: ejemplos hispánicos." Diss. Pompeu Fabra, 2009. Worldcat. Mar. 2009. Web. Aug. 2009. <http://www.tdx.cat/TDX0612109-175333>.

---. "Juan Gelman: La lengua como origen." Raíces: revista judía de cultura Verano 2006: 64-66. Print.

Matzliah Melamed, Meir, trans. Humash Ha-Mercaz. Jerusalém: Centro educativo Sefaradí En Jerusalem, 1997. Print.

Méndez, José L. Como Leer a García Marquéz, Una interpretación sociológica. Puerto Rico: Universidad De Puerto Rico, 2000. Print.

Monder, Samuel. Ficciones filosóficas: narrativa y discurso teórico en la obra de Jorge Luis Borges y Macedonio Fernández. Buenos Aires: Corregidor, 2007. Print.

Mopsik, Charles. ¿Qué es la Cábala?: preguntas y respuestas. 1st ed. Buenos Aires: Lidiun, 1994. Print.

Moshe, Shifra Bat. Fuentes judías: leyendas del Talmud y del Midrash. Jerusalém: Maor Wallach, [2003?]. Print.

Munk, Salomón. "Bosquejo histórico de la filosofía entre los judíos." Sefardica (1992): 91-127. Print.

---. "Noticia sobre León Hebreo." Sefardica (1992): 127-37. Print. 
Nuño, Juan. La filosofía de Borges. México, D.F: Fondo cultural económica, 1986. Print.

Oviedo, José M. Historia de la literatura hispanoamericana: postmodernidad, vanguardia, regionalismo. Alianza, 2001. Print.

Partisans of Vilna. Dir. Josh Waletzky. Perf. Abba Kovner. National Center for Jewish Films, 1986. DVD.

Paz, Octavio. El arco y la lira. México, D.F: Fondo Cultural Económica, 1956. Print.

Perednik, Gustavo Daniel. "Borges y su minián." Carta de Jerusalén (1993): 49-54. Print.

Pinjas Scheinberg, HaRav. Comenatrios sobre el Jumash. Comp. Shlomó Furt. Trans. Yonah Michael Elnathan. Buenos Aires: Viamonte, 2005. Print.

Pundik, Juan. "Moisés y la religión monoteísta: ¿una pesadilla de Freud?" Raíces: revista judía de cultura Verano 2006: 32-34. Print.

Purple Triangles. Dir. Martin Smith. Watchtower Bible and Track Society of New York, 1991. DVD.

Ramos, María Elena. "Palabras de despedida." Carta de Jerusalén (1993): 102-03. Print.

Rise up and Fight! Songs of Jewish Partisans. Prod. The United States Holocaust Memorial Council. Perf. Theodoro Bikel. USHMM Museum, 1996. DVD.

Rodríguez, Rodney. Momentos Cumbres De Las Literaturas Hispánicas. New Jersey: Pearson Education, 2003. Print.

Roiphe, Rebeca, and Daniel Cooper. "Batman y la cuestión judía." Raíces: revista judía de cultura Apr. 1993: 8-10. Print.

Roland, Barthes. El susurro del lenguaje: más allá de la palabra y la escritura. Barcelona: Paidós Ibérica, 2009. Print.

Romeu, Pilar. "La Música de las memorias sefardíes." Raíces: revista judía de cultura Otoño 2007: 12-17. Print.

Rose, Constance H. "Los maranos del siglo XVII y el caso del mercader- escritor: Antonio Enrique Gómez." Raíces: revista judía de cultura Invierno 1998: 3945. Print.

Safille, Bárbara. "Crueldad, simulación, absurdo y amenaza: barbarie del drama moderno y tradición hermética en los esperpentos de Ramón Del Valle Inclán." Diss. Florida International University, 2004. Print. 
Saúl, Alberto. "A los 78 años muere Sol LeWitt, pionero del arte conceptual." Raíces: revista judía de cultura Verano 2007: 4-6. Print.

---. "El Séfer Torá como objeto artístico." Raíces: revista judía de cultura Fall 2007: 4-8. Print.

Salonia, Antonio F. "De la imaginación a la realidad." Carta de Jerusalén (1993): 2122. Print.

Sassone, Helena. "Jorge Luis Borges y el judaísmo: Un tema permanente." Carta de Jerusalén (1993): 27-48. Print.

Scholem, Gershom Gerhard. Conceptos básicos del judaísmo: Dios, Creación, Revelación, Tradición, Salvación. Trans. José Luis Barbero. 3rd ed. Madrid: Trotta, 2008. Print.

---. Desarrollo histórico e ideas básicas de la Cábala. Barcelona: Riopiedra, 1994. Print.

---. El misticismo extraviado. Buenos Aires: Lilmod, 2005. Print.

---. Lenguajes y Cábala. Trans. José Luis Barbero Sampedro. Madrid: Siruela, 2006. Print.

---. Water Benjamín:historia de una amistad. Barcelona: Debolsillo, 2007. Print.

---. Jewish Gnosticism, Merkabah Mysticism and Talmudic Tradition: Based on the Israel Goldstein Lectures Delivered at the Jewish Theological Seminary of America, New York. N.Y.: Jewish Theological Seminary of America, 1965. Print.

---. Major Trends in Jewish Mysticism. New York: Schocken, 1995. Print.

---. On the Kabbalah and Its Symbolism. New York: Schocken, 1996. Print.

---. The Messianic Idea in Judaism and Other Essays on Jewish Spirituality. New York: Schocken, 1995. Print.

---. Hay un misterio en el mundo. Madrid: Trotta, 2006. Print.

---. La Cábala y su simbolismo. Madrid: Siglo XXI, 2009. Print.

---. Los Orígenes de la Cábala. Barcelona: Paidós, 2001. Print.

Shaul, Moshe. "Refleksiones sovre el Futuro de la kultura djudeo-espanyola." Carta de Jerusalen (1993): 23-26. Print.

Shaw, Donald. La nueva narrativa hispanoamericana. 8th ed. Barcelona, 1993. Print. 
Sosnowski, Saúl. Borges y la Cábala: la búsqueda del Verbo. Buenos Aires: Pardés, 1986. Print.

Sperling, Diana. "Centralidad del borde (diáspora)." Raíces: revista judía de cultura Invierno 2006: 24-30. Print.

Steimberg, Alicia. Músicos y relojeros: su espíritu inocente. Buenos Aires: Planeta, 1994. Print.

Sternhell, Zeev. Los mitos fundadores de Israel. Princenton UP, 1999. Print.

Tehilim Et Ratzón: Comentarios, leyes, costumbres, y plegarias para ocasiones especiales. Jerusalem: Feldheim, 2008. Print.

Tresoldi, Roberto. La Cábala. Barcelona: DeVecchi, 2007. Print.

The Trial. Dir. Orson Welles. Prod. Alexander Salkind. Perf. Anthony Perkins, Jeanne Moreau, Romy Schneider. 1962. DVD.

Uribe Ulloa, Pablo. "El Talmud y la literatura talmúdica." Raíces: revista judía de cultura Verano 2007: 24-29. Print.

Vargas Llosa, M., C. Blanco Aguinaga, J. Lafforgue, A. Rama, I. J. Ludmer, L. Gregorich, and N. Dottori. Nueva novela latinoamericana. Vol. 1,2. Buenos Aires: Paidós, 1976. Print.

Vattimo, Gianni. Adiós a la verdad. Barcelona: Gedisa, 2010. Print.

---. Diálogo con Nietzsche. Barcelona: Paidós, 2002. Print.

---. El fin de la modernidad. nihilismo y hermenéutica en la cultura posmoderna. Barcelona: Gedisa, 1986. Print.

Veghazi, Esteban. "Los Comienzos de la ciencia judía moderna." Coloquio (1993): 91-102. Print.

Waldman, Shmuel. Más allá de toda duda: evidencias convincentes sobre las verdades del judaísmo. 2nd ed. Buenos Aires: Perspectivas, 2006. Print.

The Warsaw Ghetto. Prod. BBC. Zenger, 1969. Videocassette.

Wikipedia Contributors. "Rashi." Wikipedia, The Free Encyclopedia. Wikipedia, The Free Encyclopedia, 16 Dec. 2010. Web. 20 Dec. 2010.

Yagupsky, Máximo G. "La epístola testamentaria de Iehudá Ibn Tibón." Sefardica (1992): 145-52. Print.

"Zohar: The Book of Splendor." Biblioteca Upasika. Trans. Pura López Colomé. Ed. Gershom Scholem. Berbera. Web. 20 Dec. 2010. 
VITA

Janet Otero Toledo

$2001-2003$

B.A., Spanish with Honors

Portland State University

Portland, Oregon

$2002-2003$

Hulda DeVaughn

Scholarship

Portland State University

Portland, Oregon

$2001-2004$

Member of the Honor

Society of Phi Kappa Phi

Portland State University

Portland, Oregon

Fall 2003

Hispanic Metropolitan

Chamber Scholarship

Portland State University

Portland, Oregon

$2003-2004$

Graduate Teacher

Education Program

Professional Teaching

License/ ESOL -

Endorsement

Master of Education

Portland State University

Portland, Oregon

2004 - Current

Spanish Teacher

Broward Public Schools

Florida 